\title{
委員会報告
}

\section{'95 日本における集中治療棟の実態}

将来計画委員会*

\section{A. 調査の概要}

\section{1) 調查の目的}

我が国における集中治療棟の設置状況ならびにその 運営状況を把握する。

\section{2）調查方法}

自記式質問紙を用いた郵送調査法。

\section{3）調查対象}

病床数 200 床以上の病院（精神病院を除く）に 200 床未満の小児病院, 循環器, 脳外科などの専門病院を 加えた1992病院を対象として予備調査を行い, 集中治 療棟を保有すると回答した 513 病院の集中治療棟 944 を対象とした。

\section{4) サンプル数}

発送総数: 944

回収総数：229

有効回答数 (集計・解析対象数) : 229

回収率 : $24.3 \%$

有効回収率 : $24.3 \%$

\section{5）調查対象者}

集中治療施設管理・運営責任者

6）回答者所属亡役職

a. 回答者所属 (図 1)

今回のアンケート調査は, 予備調査によって抽出し た集中治療棟の運営責任者宛に調查用紙を発送した。 回答者で最も多かったのはICUに所属する医師ないし 看護婦 $(34.5 \%)$ ，ついで麻酔科 $(24.0 \%)$ であった。外 科 $(10.0 \%)$ ，内科 $(9.2 \%)$ がこれに続いた。昭和 63 年度の調查結果と比較してICUに所属する回答者が多 く, 麻酔科所属の回答者が少なくなっているが, 単純 な比較は困難である。

b. 回答者役職（図 2)

$6.1 \%$ 回答者が院長・副院長・事務長であり, 前回・ 前々回の調查時と同様である。回答者のうち部長・副 部長・科長・医長が $59.4 \%$ 占め，これに看護婦長・ 主任看護婦, ICU 専従医師等を加えると $90 \%$ 越える 回答者が実際に集中治療棟の診療ないし管理運営に携 わっていることが窥われる。

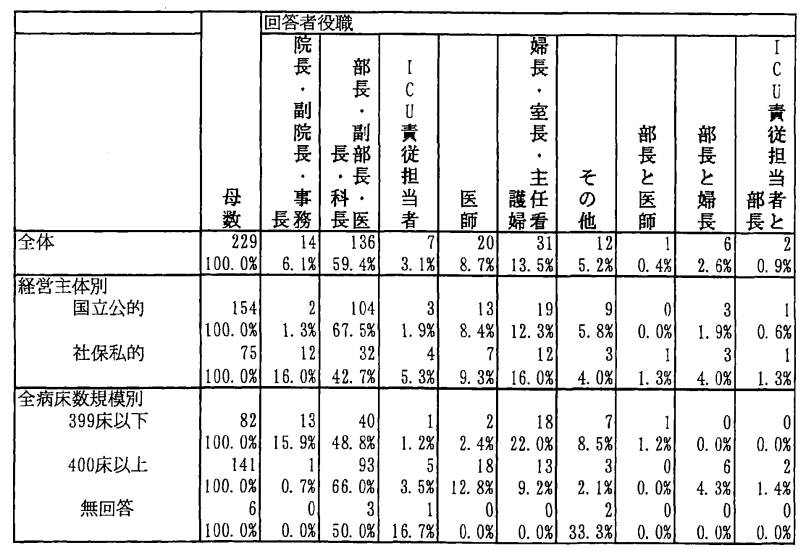

図 2

\footnotetext{
*吉矢生人 日本集中治療医学会 将来計画委員会委員長, 大阪大学医学部麻酔学（T 565 吹田市山田丘 2-2）
} 


\section{B．集中治療棟の設置状況}

\section{1）回答施設の所在地別設置状況（図 3）}

集中治療棟ありと答えた 229 医療機関の地域別分類 を最上段に示す。集中治療医学会の地方会単位では, 北海道 $7(3.1 \%)$, 東北 $17(7.4 \%)$, 関東 - 甲信越 57 (23.5\%), 東海・北陸 36 (15.7\%), 近畿 39 (17.1\%), 中国・四国 $38(16.6 \%)$ ，九州 $33(14.4 \%)$ である。こ れは, 各地方会の集中治療医学会会員数の比率とほぼ
一致する。

経営主体別にみると, 北海道, 京浜地区では社保私 的病院数が国立公的病院数を上回っているが, 他地区 では国立公的病院数が社保私的病院数を大きく上回っ ている。とくに，甲信越，京阪神，四国，東海，北陸 ではほとんどが国立公的病院である。全病床数規模別 には，東北，東海地区で 400 床以上の大病院数が 399 床以下に比して圧倒的に多い。他地区では両者のあい だに大きな開きはみられない。

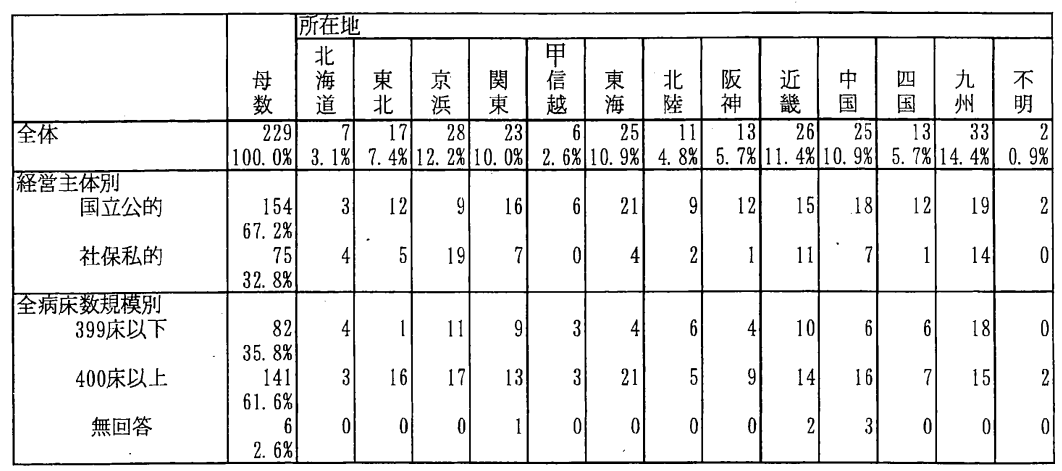

\section{2) 経営主体（図 4)}

229 医療機関中, 公立 (74), 国立 (43), その他の 公的（37）病院が 154 施設と全体の $67.2 \%$ 占める。 病床数との関係をみると国立, 公立, 公的病院ならび に学校法人では 400 床以上の施設が多い（計 167 施設 中 $122: 73 \%)$ のに対して, 私的病院では 399 床以下 が多い。

経営主体別に集中治療棟ベッド数をみると, 国立で
は 43 病院中 25 病院 $(58.1 \%)$ が $5 \sim 8$ 床， 12 病院 (27.9\%) が 1 〜 床と 86\%の病院において集中治療 棟ベッド数が 8 床以下である。公立 74 病院では 5 〜 8 床を保有しているのが 42 病院 $(56.8 \%)$ である。

3）基準看護の有無（図 5)

229 施設中 $196(85.6 \%)$ が基準看護の承認を受けて いる。この基準看護の割合は, 経営主体, 病床数, ICU ベッド数別にみても変わらない。



図 4

\begin{tabular}{|c|c|c|c|}
\hline & & \multicolumn{2}{|c|}{ 基準看護承認 } \\
\hline & $\begin{array}{l}\text { 贯 } \\
\text { 数 }\end{array}$ & \begin{tabular}{|l|} 
有 \\
⿹
\end{tabular} & \\
\hline 全体 & 229 & 196 & 33 \\
\hline & $100.0 \%$ & $85.6 \%$ & $14.4 \%$ \\
\hline 国立公的 & & & \\
\hline & $100.0 \%$ & $87.7 \%$ & 12. $3 x$ \\
\hline 社保私的 & 75 & 61 & 14 \\
\hline 全病床数規模別 & & & \\
\hline 399床以下 & 82 & 69 & \\
\hline 400床以上 & 141 & $\begin{array}{r}0.10 \\
121\end{array} \mid$ & 20 \\
\hline & & $85.8 \%$ & 14. $2 \%$ \\
\hline 無回答 & & $\begin{array}{r}6 \\
6\end{array}$ & 0 \\
\hline 藮中治療棟ベッド数別 & & & \\
\hline$\sim \sim 4$ 底 & 36 & 31 & \\
\hline $5 \sim 8$ 床 & 113 & $\begin{array}{r}-10.10 \\
98 \\
\end{array}$ & 15 \\
\hline$y \sim 12$ & $\left|\begin{array}{rr}100.0 \% \\
32\end{array}\right|$ & 86. $7 \%$ & 13. $3 \%$ \\
\hline & $100.0 \%$ & $81.3 \%$ & $18.8 \%$ \\
\hline 13床以.上 & & 40 & \\
\hline 䳞回答 & $\begin{array}{r}2 \\
100.0 \%\end{array}$ & $\begin{array}{r}1 \\
50.0 \%\end{array}$ & \begin{tabular}{|r}
1 \\
$50.0 \%$ \\
\end{tabular} \\
\hline
\end{tabular}

図 5 
4）開設年（図 6)

5 年ごとの開設数をみると, 1981 ～ 85 年が 51,1986 〜 90 年が 63,1991 〜 95 年が 28 と過去 5 年間の集

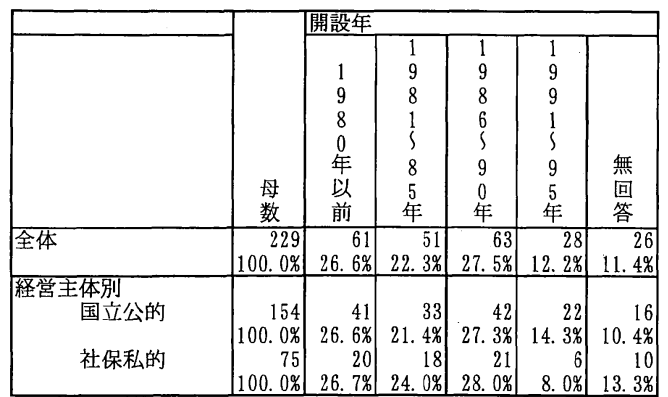

図 6-A

\section{5）集中治療棟ベッド数（図 7）}

国立公的病院では, 6 床 (39病院), 8 床 (26 病院), 4 床 (23 病院) と偶数のベッド数が多い。これは, 特 定集中治療加算の条件である必要看護職員数とベッド 数の比の規定（1：2 以上）によるものと考えられる。 社保私的病院では, 6 床を保有している病院が多いが, 必ずしも上の傾向は著明ではない。国立公的では，20
中治療棟開設数は減少している。この傾向は国立公的 病院でも社保私的病院でもほぼ同様である。

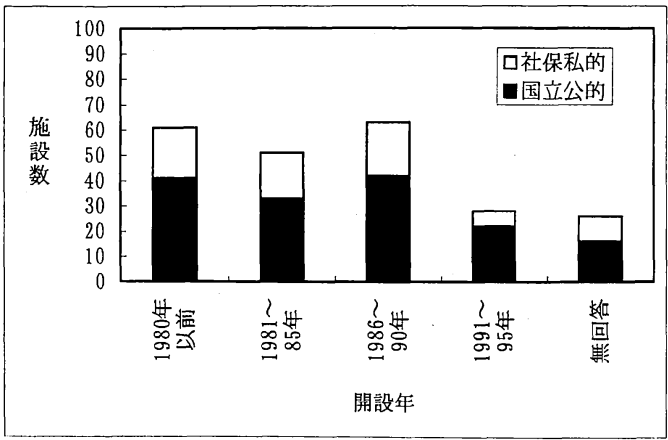

図 6-B

床以上を保有する施設が 16 あったが，9床以上を保有 する施設の割合は国立公的で $26.5 \%$ あるのに対し， 社保私的では $48.0 \%$ と後者に大きい集中治療棟を保有 する施設が多かった。

全病床数 400 床以上と 399 床未満とでは, 保有 ICU ベッド数の分布に差は認められない。

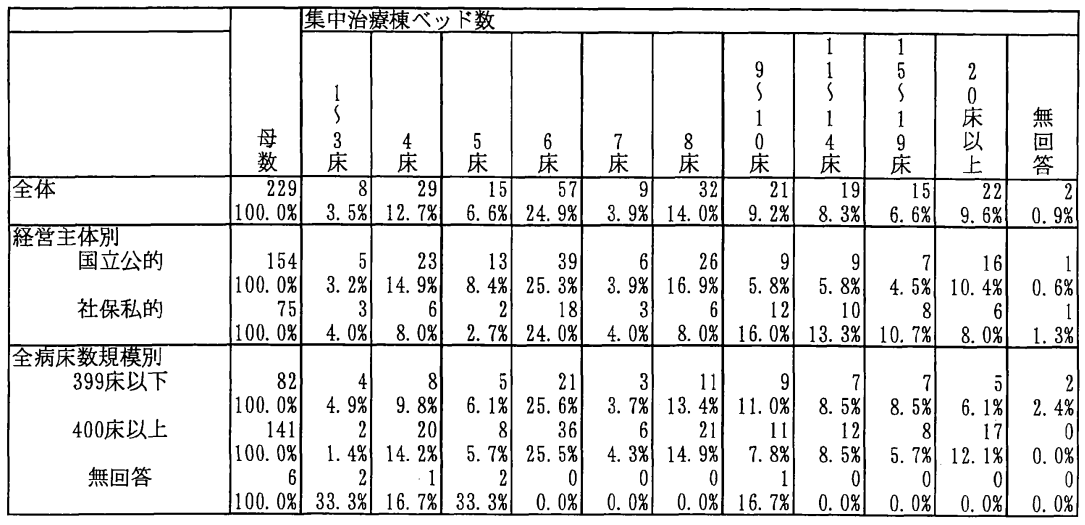

図 7-A



図 7-B

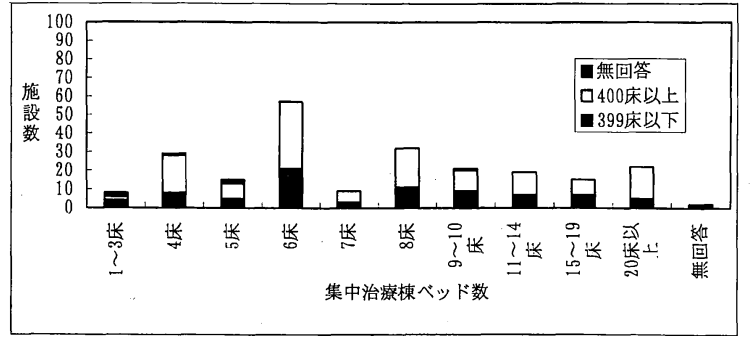

図 7-C 
6) 総ベッド数（図 8)

国立公的病院では, $600 \sim 699$ 床 (21.4\%) が最も多 く, ついで $300 \sim 399$ 床 (14.3\%), 500 ～ 599 床（13.6 \%), $700 \sim 799$ 床 $(13.0 \%)$ と 600 ～ 699 床をピーク とした比較的大病院が多い。これに対して, 社保私的

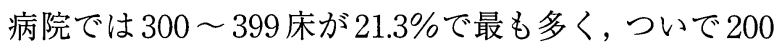
〜 299 床が 18.7\%，199 床以下が 12.0\%と小規模病院 が多い一方で 1000 床以上の大病院が $13.3 \%$ あ。しか し, 集中治療棟ベッド数は総病床数の増加と平行して 増加しているわけではない。

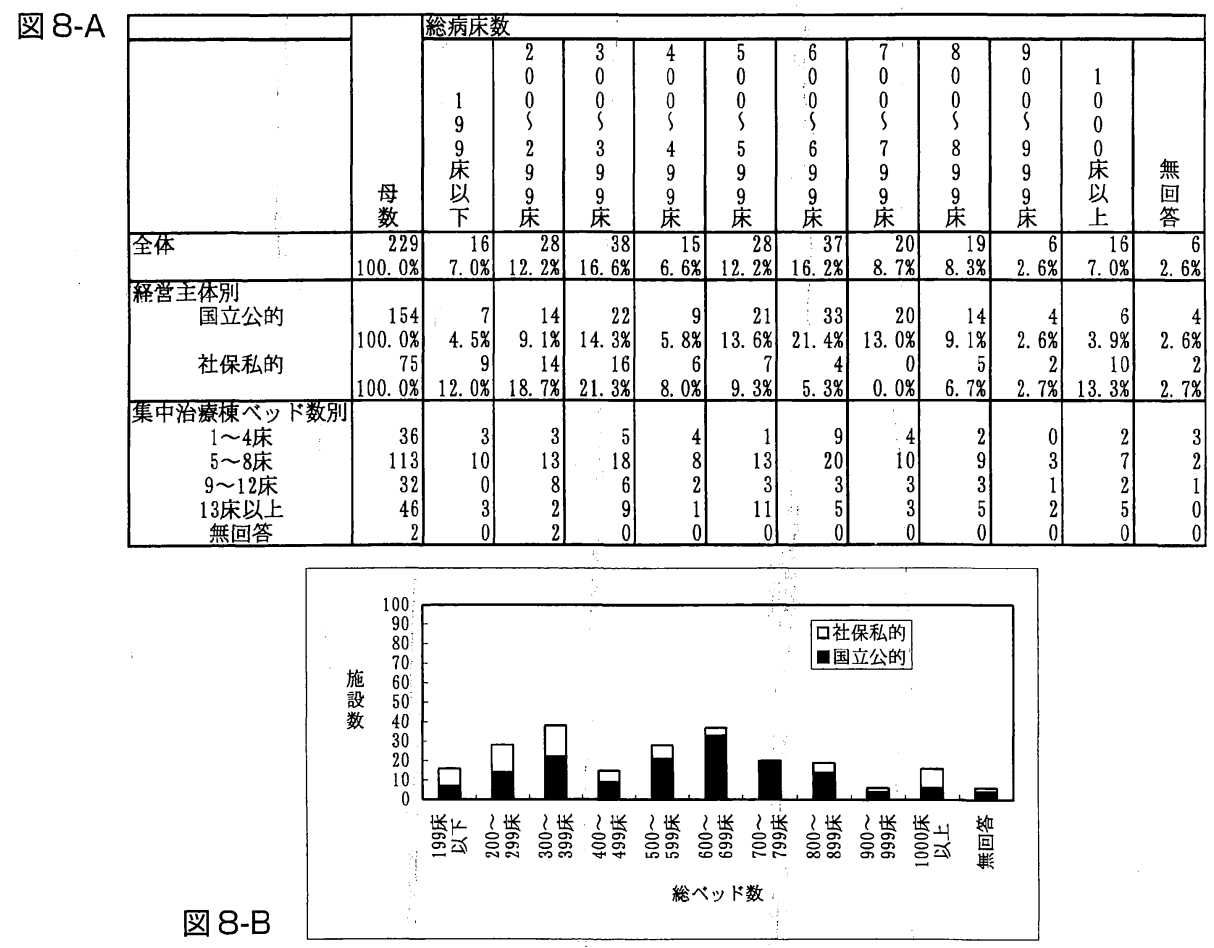

7）集中治療棟の分類（図 9）

総合的集中治療部 (ICU) を有するとの回答が 229 施 設中 $133(58.1 \%)$ あり，ついで外科系疾患 ICU が 24 $(10.5 \%)$, 救急部・救急救命センターが $21(9.2 \%)$ 施 設である。冠疾患 ICU : 6 (2.6\%), 呼吸器疾患 ICU : $2(0.9 \%)$, 新生児 ICU : $3(1.3 \%)$, 小児 ICU $: 3(1.3$ $\%)$ と今回の調查では内科系ならびに小児・新生児ICU
が少ない。予備調查（付表）に比し回答率に偏りがあ るとしても, 我が国では集中治療棟の専門分化が遅れ ていることを反映していると考えられる。

経営主体別ならびに全病床規模別には，国立公的病 院ならびに 400 床以上の病院に総合的 ICU が多く, 専 門分化したICUが少ない傾向がある。社保私的病院な らびに 399 床以下の病院では, その逆の傾向がある。

図 9-A

\begin{tabular}{|c|c|c|c|c|c|c|c|c|c|c|c|}
\hline & & 集中核 & 台療棟 & & & & & & & & \\
\hline & 霰 & $\begin{array}{l}\text { 総 } \\
\text { 合 } \\
\text { 的 } \\
\text { 集 } \\
\text { 中 } \\
\text { 治 } \\
\text { 療 } \\
\text { 部 }\end{array}$ & $\begin{array}{l}\text { 外 } \\
\text { 科 } \\
\text { 系 } \\
\text { 疾 } \\
\text { 患 } \\
\text { 集 } \\
\text { 治 } \\
\text { 察 } \\
\text { 部 }\end{array}$ & 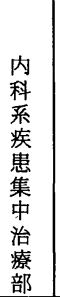 & $\begin{array}{l}\text { 冠 } \\
\text { 潧 } \\
\text { 集 } \\
\text { 治 } \\
\text { 爒 } \\
\text { 部 }\end{array}$ & $\begin{array}{l}\text { 呼 } \\
\text { 吸 } \\
\text { 瘜 } \\
\text { 集 } \\
\text { 治 } \\
\text { 潦 } \\
\text { 部 }\end{array}$ & 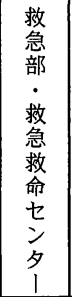 & 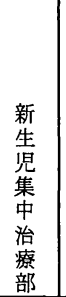 & $\begin{array}{l}\text { 小 } \\
\text { 膲 } \\
\text { 售 } \\
\text { 涘 } \\
\text { 尞 } \\
\text { 部 }\end{array}$ & $\begin{array}{l}\text { 複 } \\
\text { 数 } \\
\text { 罟 }\end{array}$ & 箇答 \\
\hline 全体 & $\begin{array}{r}229 \\
100.0 \%\end{array}$ & $\begin{array}{r}133 \\
58.1 \%\end{array}$ & $\begin{array}{r}24 \\
10.5 \%\end{array}$ & 0.48 & $\begin{array}{r}6.6 \% \\
\end{array}$ & $\begin{array}{r}2 \\
0.9 \%\end{array}$ & $\begin{array}{r}21 \\
9.28\end{array}$ & $\begin{array}{r}3 \\
1.3 \% \\
\end{array}$ & 1. 36$]$ & $\begin{array}{r}31 \\
13.5 \%\end{array}$ & \\
\hline $\begin{array}{l}\text { 経営主体別 } \\
\text { 等公的 } \\
\text { 社保私的 }\end{array}$ & \begin{tabular}{r|}
154 \\
$100.0 \%$ \\
75 \\
$100.0 \%$
\end{tabular} & \begin{tabular}{r|}
0.10 \\
97 \\
63.08 \\
36 \\
48.08
\end{tabular} & \begin{tabular}{r|r|}
1.0 \\
$11.7 \%$ \\
6 \\
$8.0 \%$
\end{tabular} & $\begin{array}{r}0 \\
0.0 \% \\
1 \\
1 \\
3 \%\end{array}$ & $\begin{array}{r}3 \\
1.96 \\
3 \\
4.0 \%\end{array}$ & $\begin{array}{r}1 \\
0.6 \% \\
1 \\
1\end{array}$ & $\begin{array}{r}12 \\
7.8 \% \\
9 \\
12.0 \%\end{array}$ & $\begin{array}{r}1 \\
0.6 \% \\
2 \\
2.78\end{array}$ & $\begin{array}{r}0.6 \% \\
2 \\
2.78\end{array}$ & \begin{tabular}{r|}
19 \\
12.38 \\
12 \\
16.08
\end{tabular} & \\
\hline 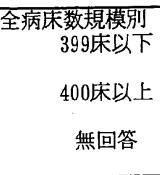 & $\begin{array}{r}82 \\
100.0 \% \\
141 \\
100.0 \% \\
6 \\
100.0 \%\end{array}$ & $\begin{array}{r}42 \\
51.2 \% \\
89 \\
63.1 \% \\
2 \\
33.3 \% \\
\end{array}$ & $\begin{array}{r}11 \\
\text { 13. } 4 \% \\
12 \\
8.5 \% \\
1 \\
16.7 \%\end{array}$ & $\begin{array}{r}1.2 \% \\
0 \\
0.0 \% \\
0 \\
0.0 \%\end{array}$ & $\begin{array}{r}3 \\
\text { 3. } 7 \% \\
3 \\
\text { 2. } 1 \% \\
0 \\
0.0 \% \\
\end{array}$ & $\begin{array}{r}1.2 \% \\
1 \\
0.7 \% \\
0 \\
0.0 \%\end{array}$ & $\begin{array}{r}5 \\
6.1 \% \\
16 \\
11.3 \% \\
0\end{array}$ & $\begin{array}{r}1 \\
\text { 1. } 28 \\
1 \\
0.78 \\
1\end{array}$ & $\begin{array}{r}3 \\
3.78 \\
0 \\
0.08 \\
0 \\
0.08\end{array}$ & $\begin{array}{r}13 \\
15.9 \% \\
17 \\
12.18 \\
1 \\
16.78\end{array}$ & 1. \\
\hline
\end{tabular}


図 9-B

\begin{tabular}{|c|c|}
\hline 1.3\% & 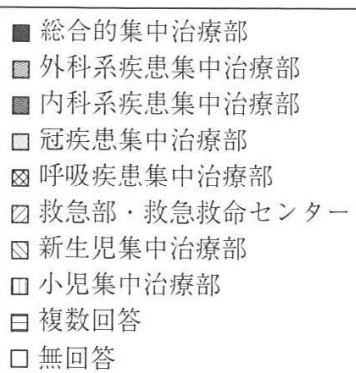 \\
\hline
\end{tabular}

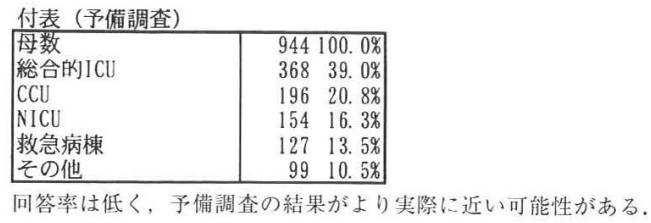

\section{C. 集中治療棟の診療体制}

\section{1）管理責任者所属（図 10)}

全体としては，麻酔科医が管理責任者となっている 集中治療棟が $29.7 \%$ と最も多く, ICU 専従医が責任者 となっているのは $21.4 \%$ である。外科系（外科，心臓 外科, 胸部外科, 脳神経外科）が責任者となっている のは計 $17.9 \%$ ，内科系は 10.5\%である。

経営主体別の管理責任者は，国立公的病院では麻酔
科医の比率が $35.7 \%$ と多い。社保私的病院では, 麻酔 科医が $17.3 \%$ と少なく，外科 $(14.7 \%)$ 内科 (17.3\%) の比率が高くなっている。ICU 専従医の割合には経営 主体別の差がない。

病床数の規模別には，400 床以上の病院で麻酔科医 (36.9\%)，ICU 専従医 $(29.8 \%)$ の比率が高く，399 床 以下では外科系, 内科系の医師が管理責任者となって いる施設が多い傾向にある。

図 10-A

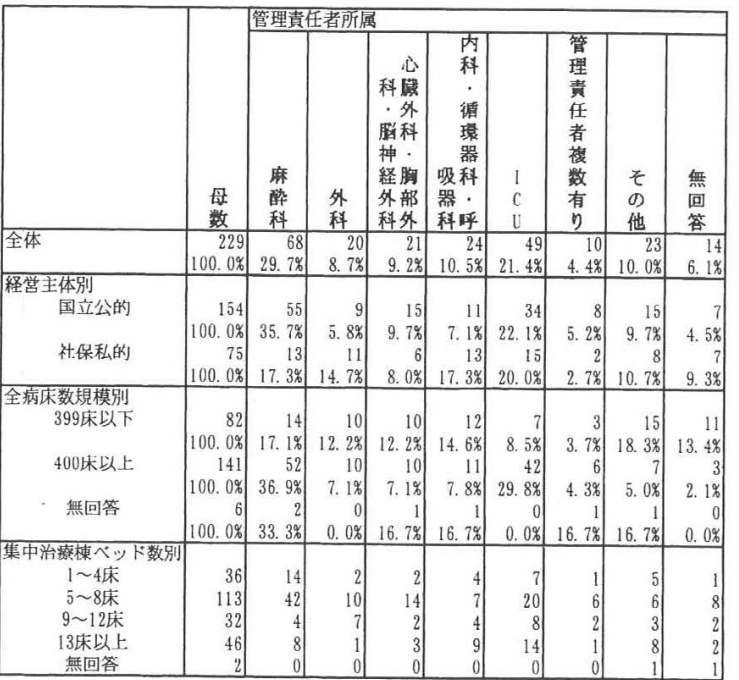

図 10-B

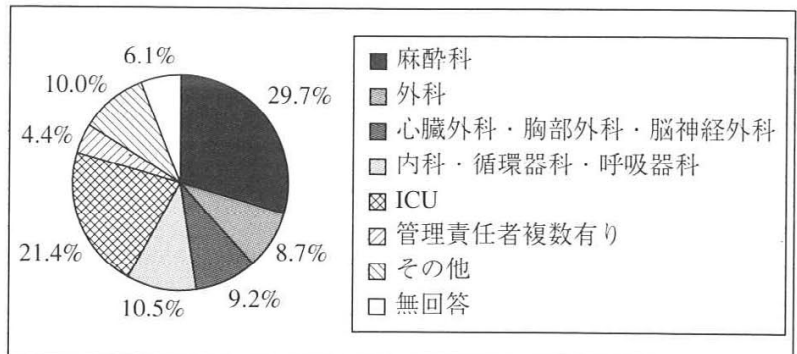


己）診療責任者所属（図 11）

ICU専従者が骖療責任者となっている施設が最も多

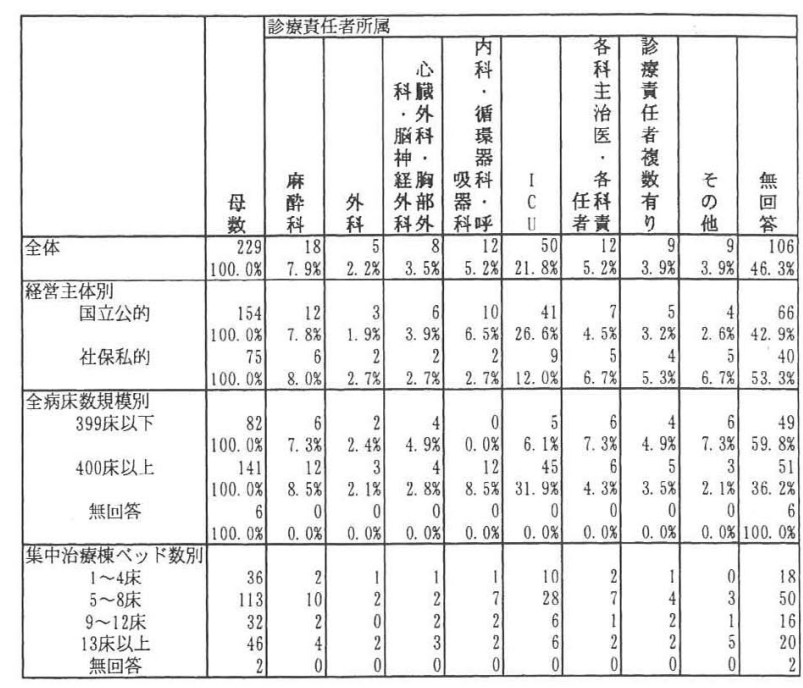

図 $11-A$

\section{3）管理責任者専従有無（図 12）}

全体として, 専従の管理責任者を有する集中治療棟 は $46(20.1 \%)$ しかなく, 残りは管理責任者が兼務者 である。経営主体別には管理責任者の専従の有無には 差がなかったが，400 床以上の病院（23.4\%）では専従 の管理責任者を有する割合が 399 床以下（14.6\%）に 比して多い。集中治療棟ベッド数別では, 1 ～ 4 床に おいて専従の管理責任者をおいている施設が 2 施設 $(5.6 \%)$ のみである。
い $(21.8 \%)$ 。この傾向は, 国立公的病院 $(26.6 \%), 400$ 床以上の病院 $(31.9 \%)$ で顕著である。

図 $11-B$

\section{4）診療責任者専従有無（図 13）}

全体として, 専従の診療責任者を扔いている集中治 療梀は $67(29.3 \%)$ にすぎない。経営主体別には，国 立公的病院の方が尃従骖療責任者を扔いている割合が 大きい。また， 400 床以上の病院では $41.1 \%$ が専従責 任者を有するのに対し 399 床以下では 11.0\%である。 集中治䝤棵ベッド数に関しては, ベッド数の増加とと もに専従診療責任者を有する割合がむしろ減少する傾 向がある。

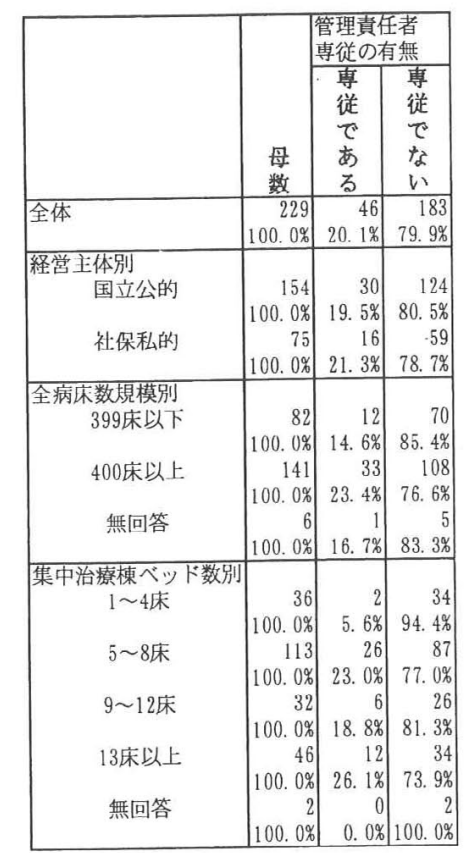

図 12

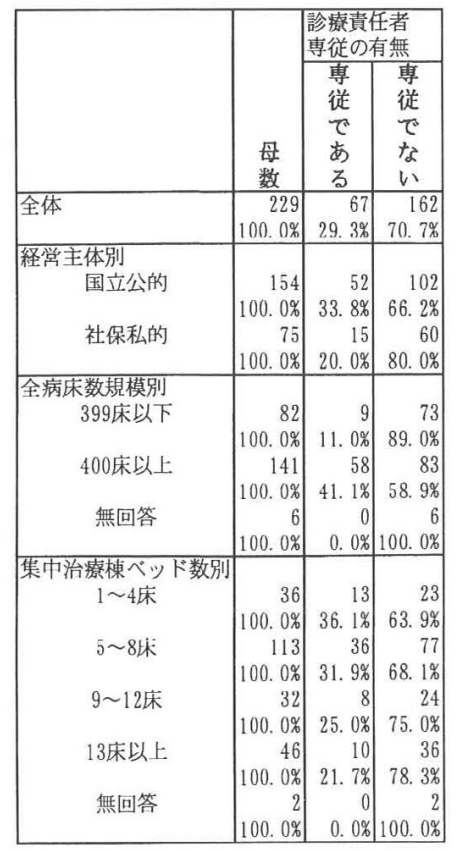

図 13 
5）入退室決定（図 14）

ICU責任担当医ならびに責任医が入退室の決定を行 う施設が $67.2 \%$ を占める。ICU 責任担当者と主治医な
いし婦長との合意による決定を加えると， $73.8 \%$ の施 設に扔いて ICU 専従医が入退室の決定に関わってい る。

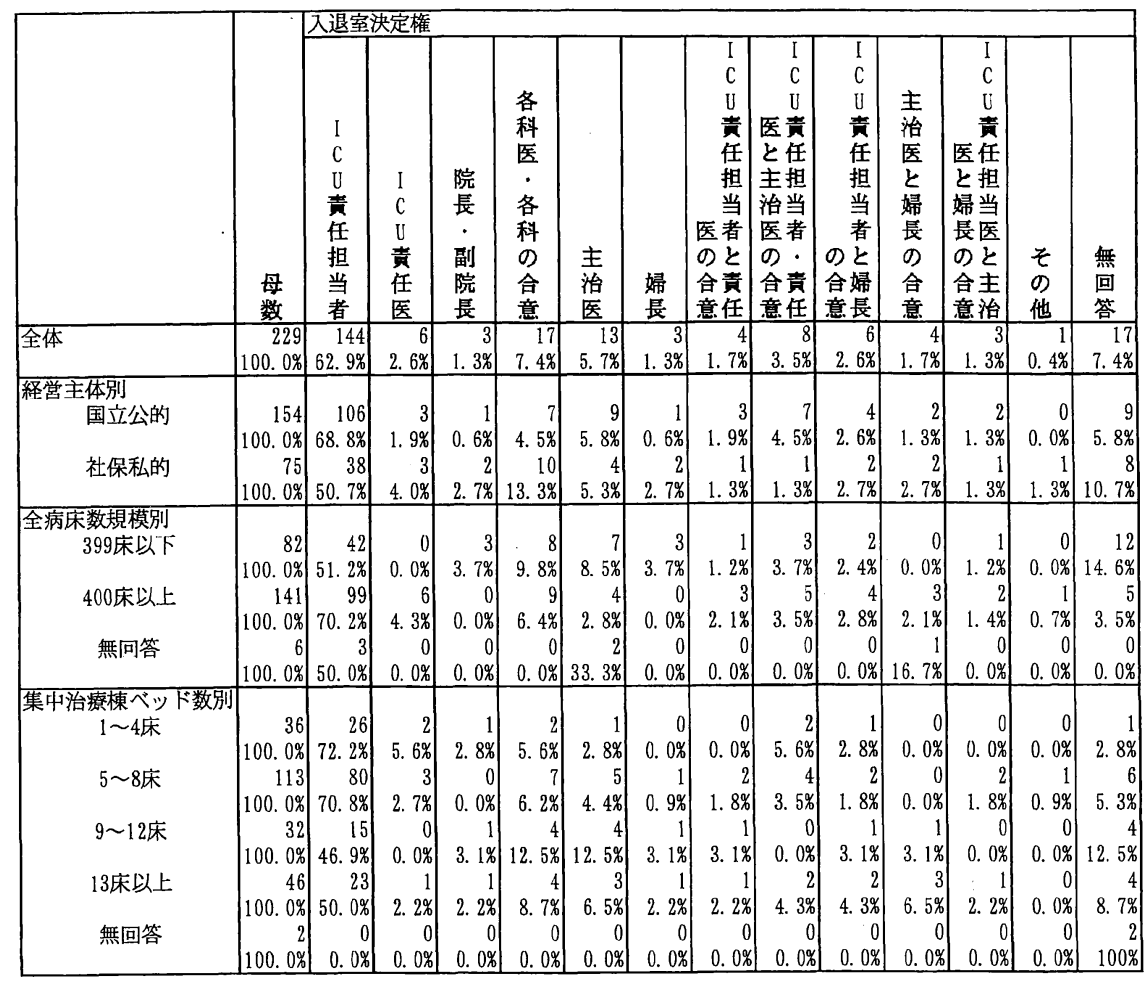

図 14

\section{D. 集中治療棟の運営状況}

1）年間症例数（図 15）

全体の年間症例数は, $200 \sim 299$ 人, $300 \sim 399$ 人, 400 ～ 499 人がそれぞれ $27(11.8 \%), 28(12.2 \%), 25$ $(10.9 \%)$ で, 199 人以下の 15 施設を加えると計 95 (41.5 \%)の集中治療棟において年間症例数が 500 人未満に
とどまっている。 500 人以上では, $500 ＼mathrm{~ 599 ， 600 ～ ~}$ 699 がそれぞれ $10(4.4 \%)$ 施設で以降漸減しているが, 1000 以上の年間症例数を有する施設も19（8.3\%） あ る。経営主体別にみると国立公立に比して社保私的病 院の方が年間症例数の多い傾向がある。保有集中治療 ベッド数が多いことに起因していると思われる。

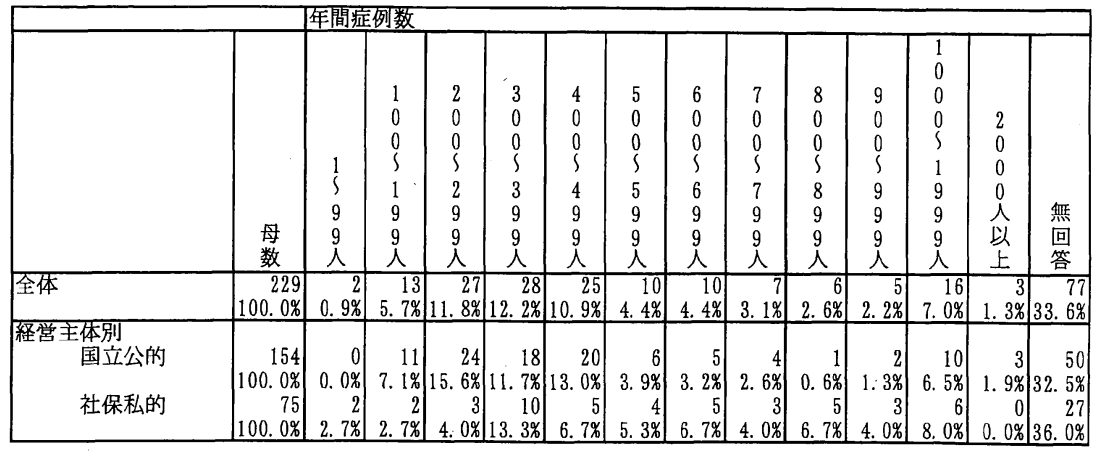

図 15-A 


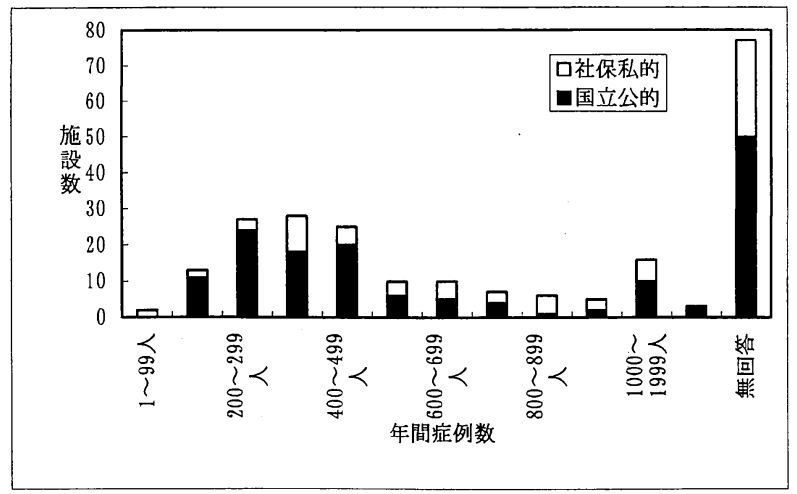

図 15-B

2）症例内訳（図 16）

集中治療棟への入室理由となった原疾患別に，入室 経路と年間入室者数を調査した。年間入室者数につい ては，疾患別の統計が取られていない施設がある可能 性を考慮し，年間 10 人以上，同 9 人以下，なし，の 3 種の答えについて施設数を調べた。

脳神経・神経筋疾患については，術後入室，救急外 来よりの入室者が年間 10 名以上の施設がそれぞれ 100 を超えたが，病棟よりの入室ならびに他医よりの紹介 入室が年間 10 名以上の施設は少ない。循環器疾患につ いては，病棟より，術後入室，救急外来より，のそれ ぞれについて 100 を超える施設において年間 10 名以 上の入室者がある。他医よりの紹介入室も 91 施設にお いて年間 10 名を超える。

年間 10 人以上の入室者がある施設数を入室経路 (病 棟より，術後入室，救急外来より，他医より）につい て比較すると, 脳神経・神経筋疾患では術後 (105), 救 急外来（111）が多く病棟（40），他医（47）が少ない。 循環器疾患では, 病棟 (113), 術後 (130), 救急外来
（136）が多く，他医も 91 施設ある。呼吸器疾患では, 術後 (109), 病棟 (96), 救急外来 (95) が比較的多く, 他医は 52 と少ない。消化器疾患では, 術後（152）が 飛び抜けて多く, 救急外来 (71), 病棟 (44), 他医 (30) は少ない。肝・腎・脾も消化器疾患と同様の傾向があ るが, 年間 10 人以上の症例数を有する施設が後者に比 して少ない。内分泌・代謝ならびに血液・免疫では，い ずれの入室経路においても入室者無しの施設が最も多 く，入室者有りの場合もほとんどが年間 9 人以下であ る。外傷（熱傷を含む）症例は，当然ながら救急外来 （87）が最も多く，ついで術後（43），他医（31）であ るが，いずれにせよ年間 10 人以上の入室者を有する施 設は脳神経・神経筋, 循環, 消化器と比べると少ない。 中毒症例についてはさらにこの傾向が強い。これは， 今回の解析対象施設のうち救命救急センターが約 $10 \%$ を占めるに過ぎず，他のほとんどが院内重症患者を対 象とする集中治療棟であることを反映していると考え られる。

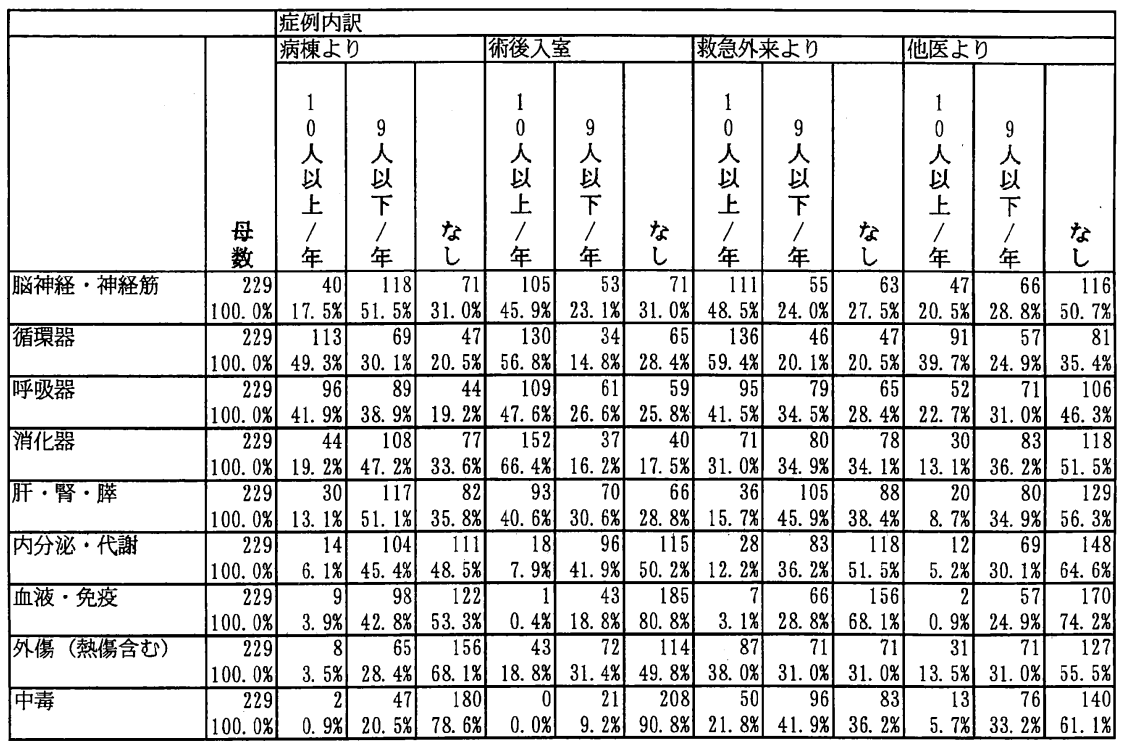

図 16-A

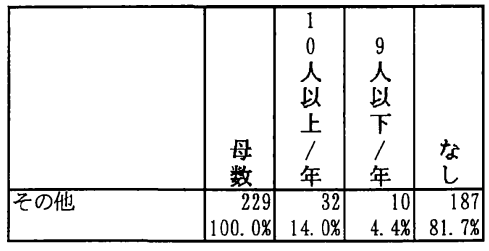




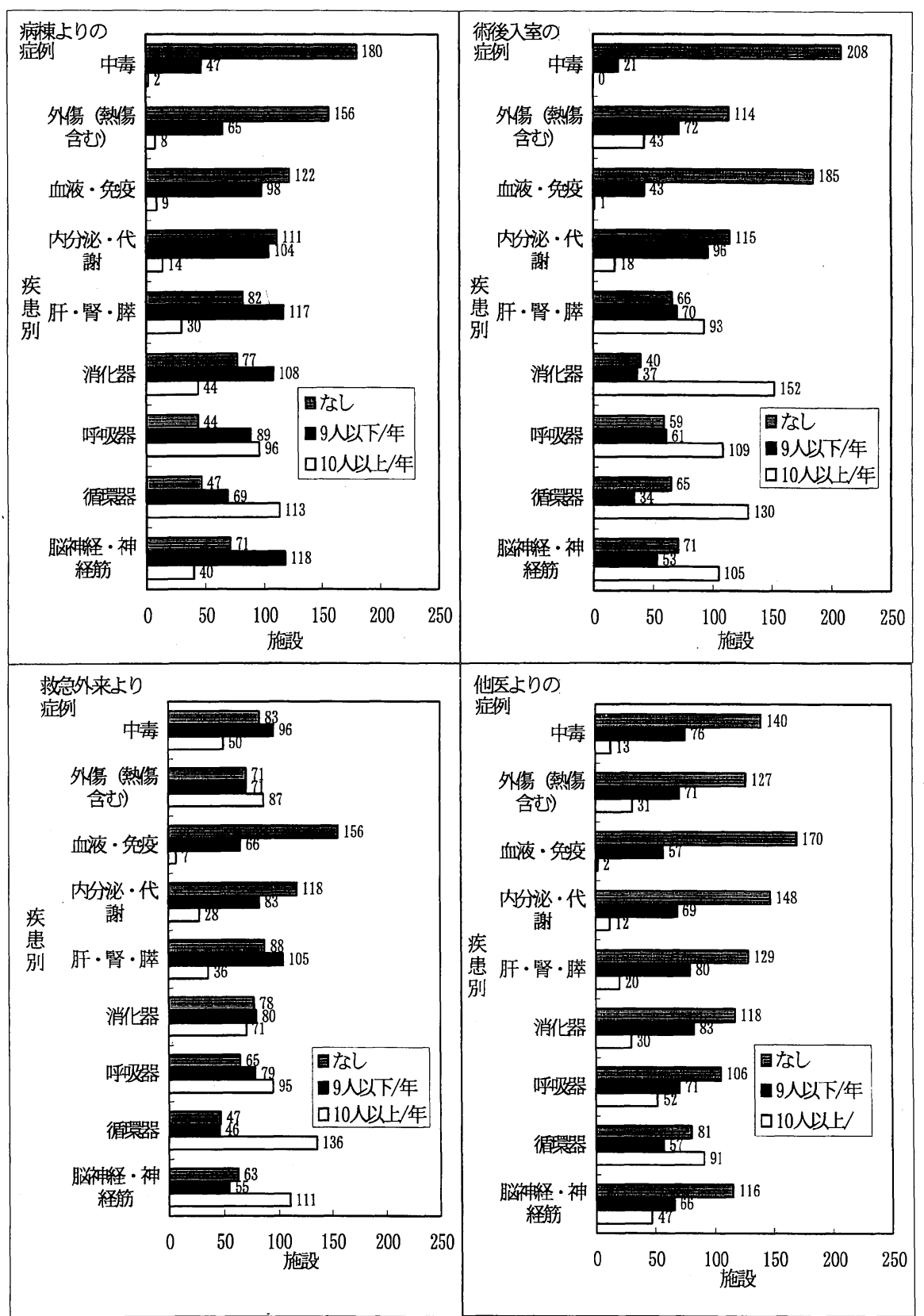

図 16-B 


\section{3) 年齢別入室患者数 (図 17)}

集中治療棟に入室する年齢層をみると, 31 ～ 50 歳, $51 \sim 70$ 歳, 71 歳以上で年間 10 名以上の入室者があ る施設が多い。高年齢層の入室者が多いのは, 今回の
対象が，術後患者や呼吸・循環系の急性症を取り扱う 施設が多いことを反映するものと思われる。新生児の 入室者が少ないのは, 絶対数が少ないことと今回の調 査で NICU の回答率が低かったためと思われる。

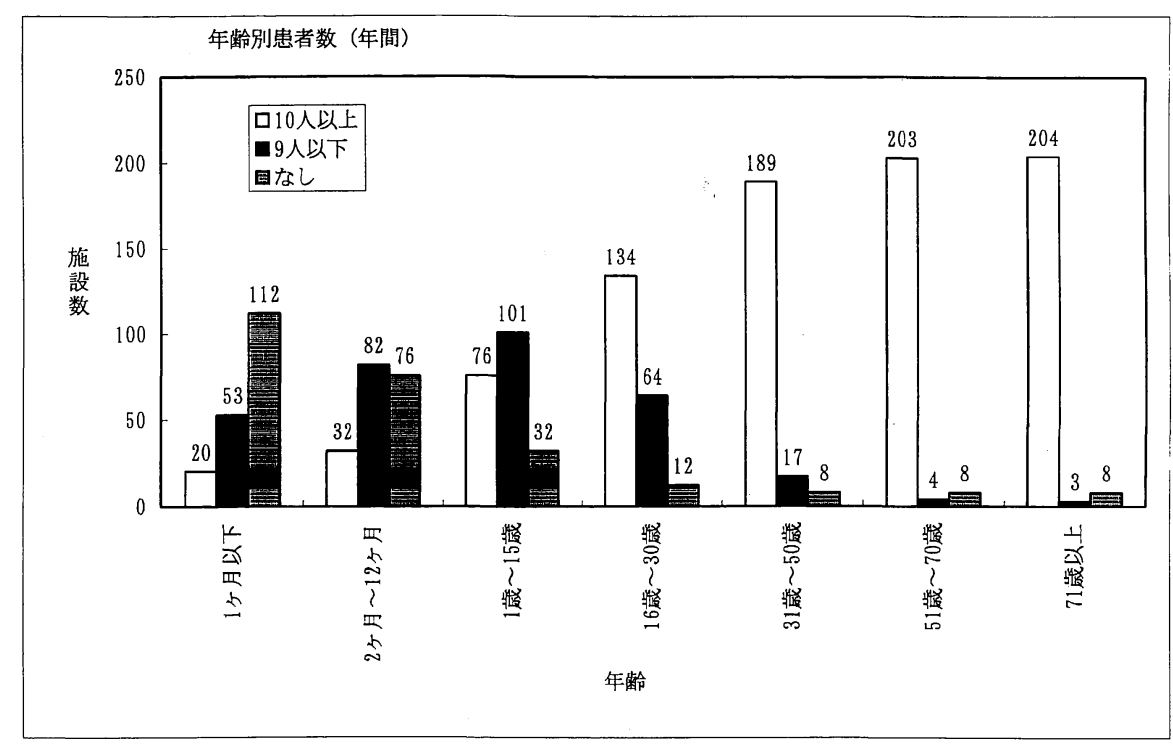

図 17

\section{4）入室患者の平均入室日数（図 18）}

全体として平均入室日数が 7 日以内の施設が 154 (67.2\%)，8 日以上が 46 (20.1\%) である。術後症例と 非術後症例を比較すると, 術後で平均 7 日以内の施設
が 178 (77.7\%) であるのに対し，非術後では $108(47.2$ \%)と少ない。国公立病院では社保公的病院に比して, 7 日以内の入室率が高い傾向がある。

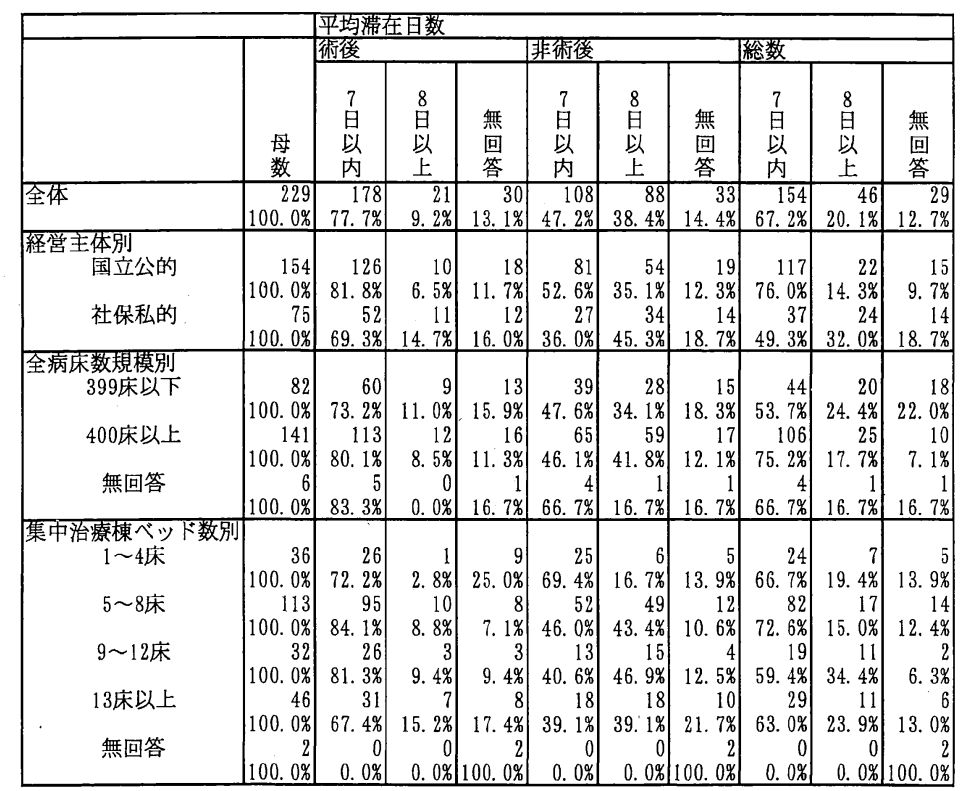

図 18-A 


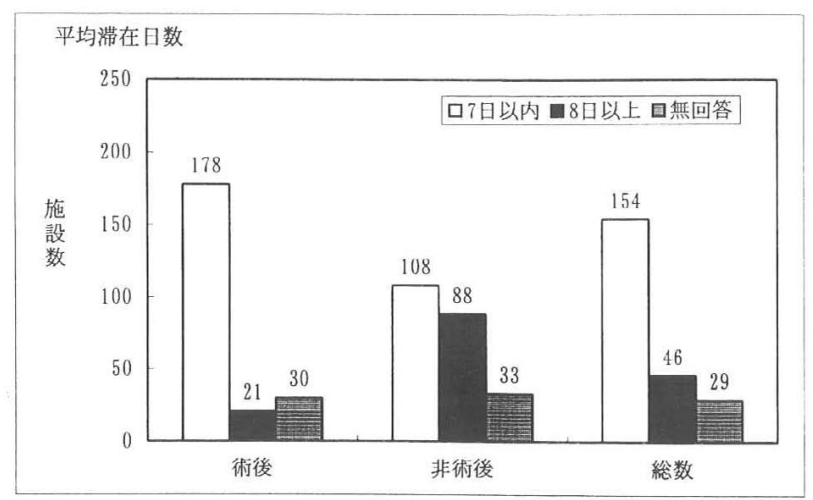

図 18-B

5）診療上の運営（図 19）

a. 診療方針決定者

診療方針は，各科の主治医が決定する施設が 104 (45.4\%) と最も多く, ついで集中治療棟専従医と各科 主治医の協議による施設が 81 （35.4\%）である。専従 医単独で診療方針を決めるのは31（13.5\%）であるが,
後 2 者を合わせると約半数の施設で専従医が診療方針 決定に関与していることがわかる。

b. 看護婦（士）への指示

上と同様に, 約半数の施設で専従医が看護婦 (土) へ の指示を行っている。
図 19-A

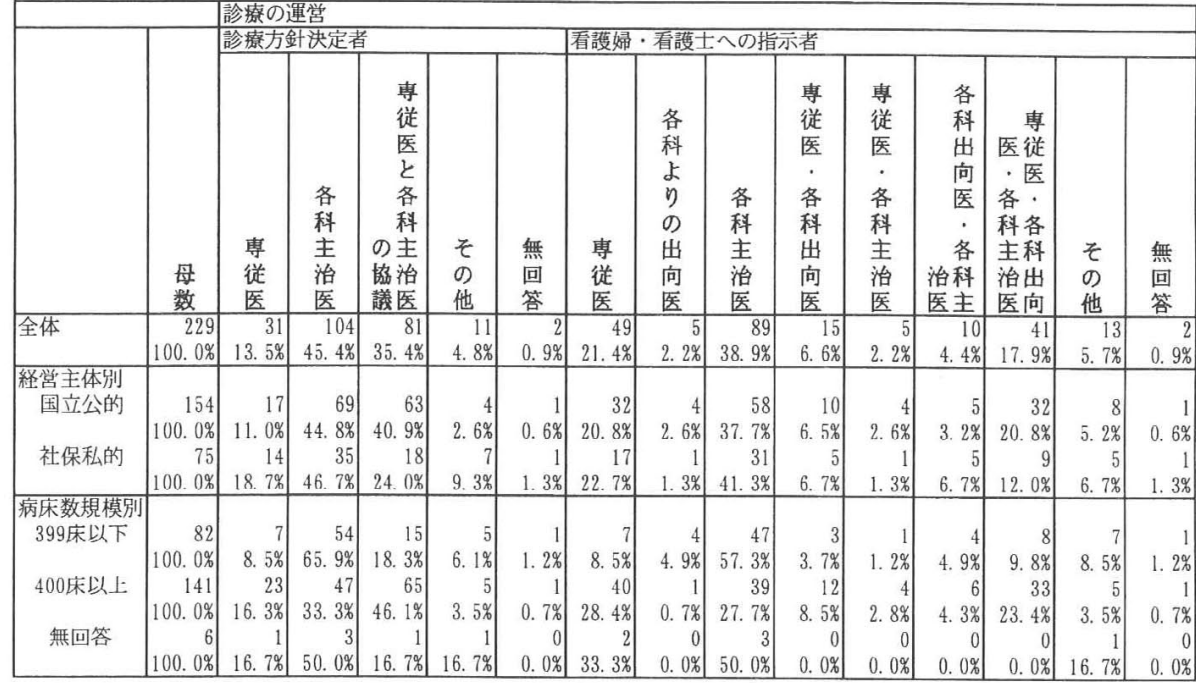

図 19-B

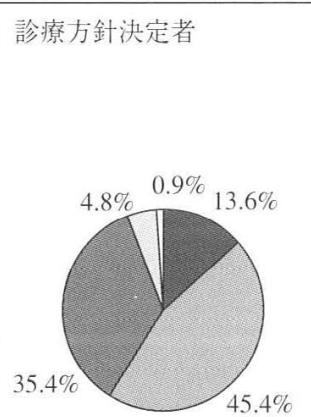



$\square$ 無回答

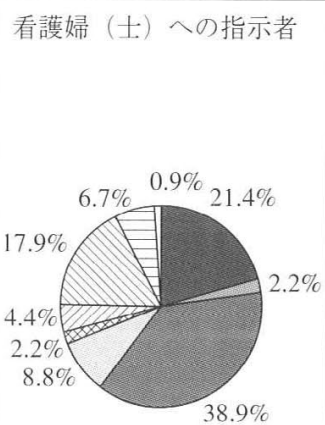

専従医

口各科よりの出向医

國各科主治医

$\square$ 専従医 .

各科出向医

専従医 .

各科主治医

曰各科出向医。

各科主治医

曰専従医·各科出向

医・各科主治医

曰その他

$\square$ 無回答 


\section{c. 患者・同家族への説明（図 20）}

各科主治医が単独で説明を行う施設が 146 (63.8\%) を占め, 専従医の関与は診療方針の決定に比して低い。 d. 入退室の決定

各科責任者が入退室の決定を行う施設は 36 (15.7\%)
で，多くの施設（135：58.2\%）で集中治療部の管理運 営者, 診療責任者, 当番の専従医師が入退室の決定に 当たっている。看護婦長が入退室の決定を行う施設も 少数 $(7: 3.1 \%)$ ある。

図20-A

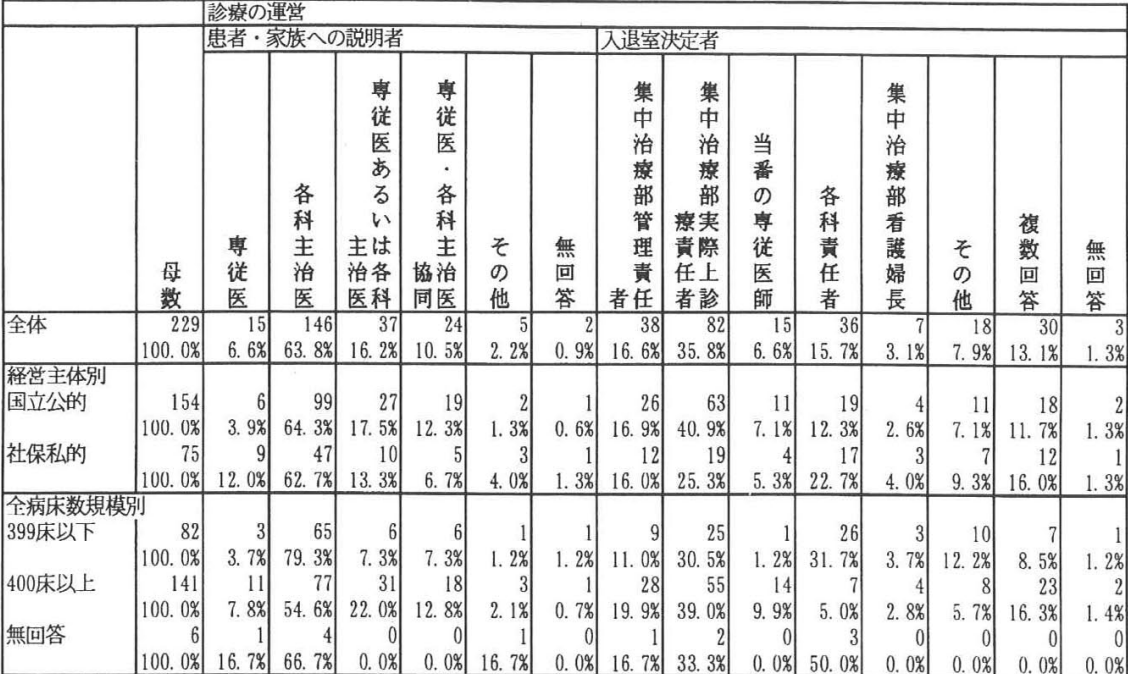

図20-B

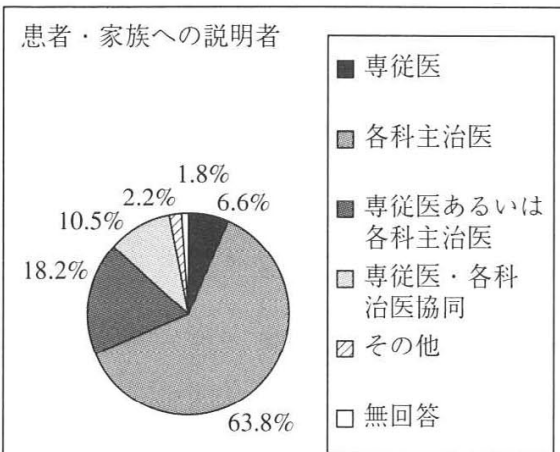

入退院決定者

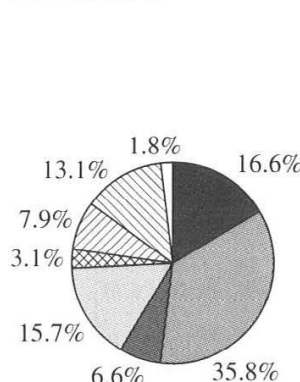

$35.8 \%$
集中治療部管理 責任者

口集中治療部実際 上診療責任者

当番の専従医師

口各科責任者

四集中治療部看護 婦長 『その他

曰複数回答

$\square$ 無回答 


\section{E. 医師の診療体制}

\section{1）日勤医師数：総数（図 21）}

平日 1 日当たりの平均日勤総医師数は, $1.0 〜 3.9$ 人 が $31.0 \%$ と最も多く, ついで $4.0 \sim 6.9$ 人が $24.0 \%$ で 7 人未满が $55 \%$ を占める。集中治療棟ベッド数別にみる と, $1 \sim 4$ 床では $1.0 \sim 3.9$ 人の日勤医師数が $55.6 \%$ と
圧倒的に多い。 $5 \sim 8$ 床では $1.0 \sim 3.9$ 人と $4.0 \sim 6.9$ 人がそれぞれ $32.7 \%$ と $29.2 \%$ で計 $61.9 \%$ を占める。9 12 床では, $1.0 \sim 3.9$ 人, $4.0 \sim 6.9$ 人, $7.0 \sim 9.9$ 人が それぞれ $21.9 \%, 31.3 \%, 21.9 \%$ と勤医師数が多い方 ヘシフトしている。13 床以上では, 日勤医師数は 1.0 人から 49.9 人までの間にまんべんなく広がっている。

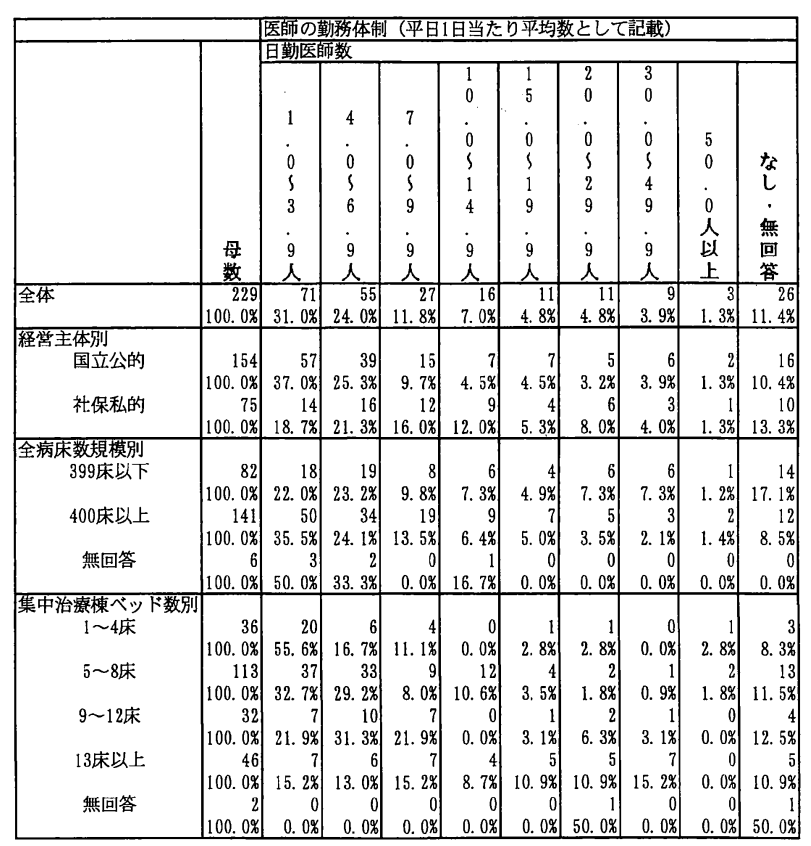

図21

2）日勤医師数：専従医（図 22）

全体として, $1.0 \sim 1.9$ 人 $(20.1 \%), 2.0 \sim 2.9$ 人 (14.4

\%) で，34.5\%の集中治療棟で日勤専従医師数が 3 人
未満である。一方, 専従日勤医師がいないという回答 と無回答が合わせて $45.4 \% に$ 達している。この傾向は, 集中治療棟ベッド数別にみても変わらない。

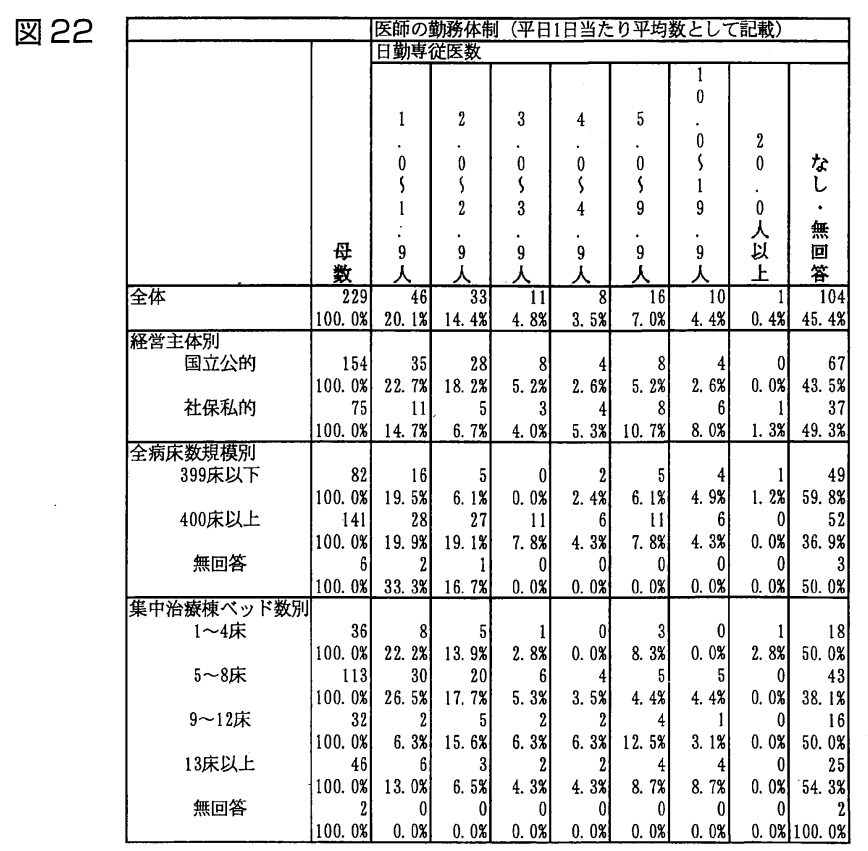


3）日勤医師数：研修医（專従）（図 23）

$1.0 \sim 1.9$ 人 . $(10.5 \%), 2.0 \sim 2.9$ 人 (8.7\%) 計 $19.2 \%$
の集中治療棟で 3 人未満の研修医を日勤させているが， $70.3 \%$ 研修医を勤務させていないか無回答である。

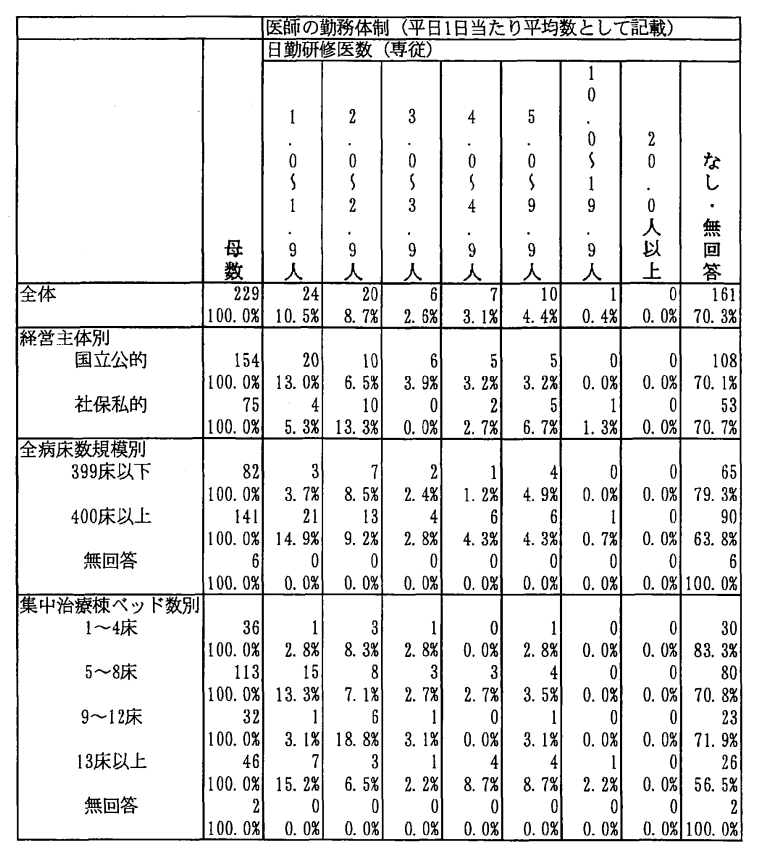

図23

4) 夜勤医師数：総数（図 24）

平均夜勤医師数（総数）は, $1.0 \sim 1.9$ 人が $37.1 \%$, $2.0 \sim 2.9$ 人が $27.1 \%$ で, 3 人未満が $64.2 \%$ と大半を占
める。経営主体別, 全病床数規模別, 集中治療ベッド

数別にみても総数の傾向と変わりはない。

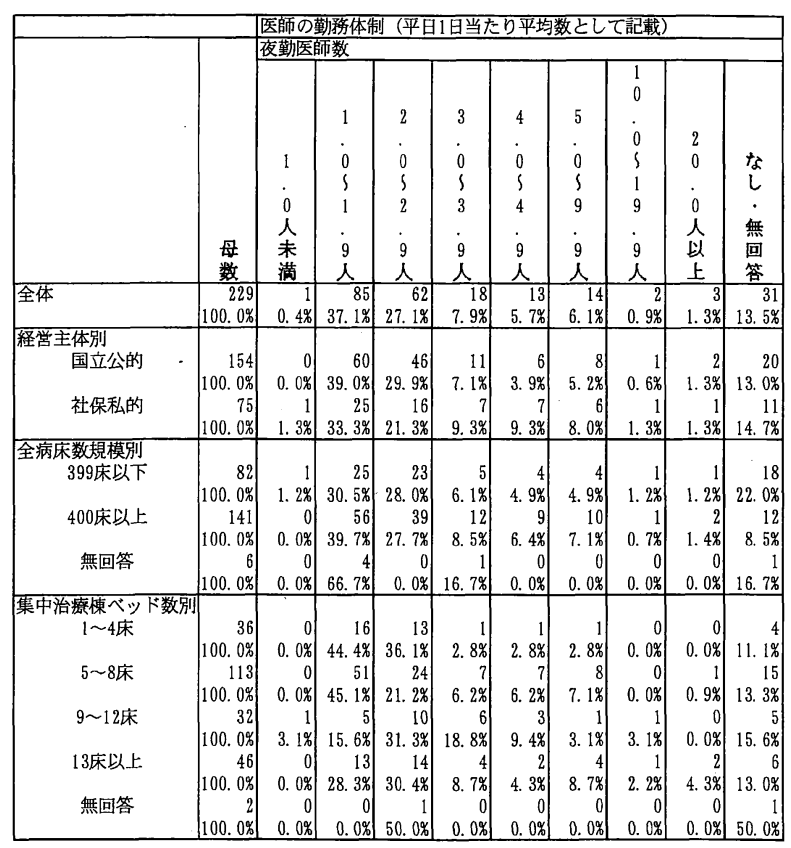

図24 
5）夜勤医師数：專従（図 25）

$1.0 \sim 1.9$ 人の夜勤医師数（専従）を有している集中 治療棟は $33.2 \% て ゙ あ り ， 2$ 人以上の専従医が夜勤をし ている施設は少ない。57.6\%の回答が「なし」ないし
「無回答」である。全病床数規模別には, 専従医が夜勤

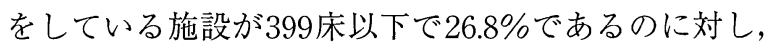
400 床以上では $51.8 \%$ と高い。経営主体別, 集中治療 ベッド数別には差はみられない。

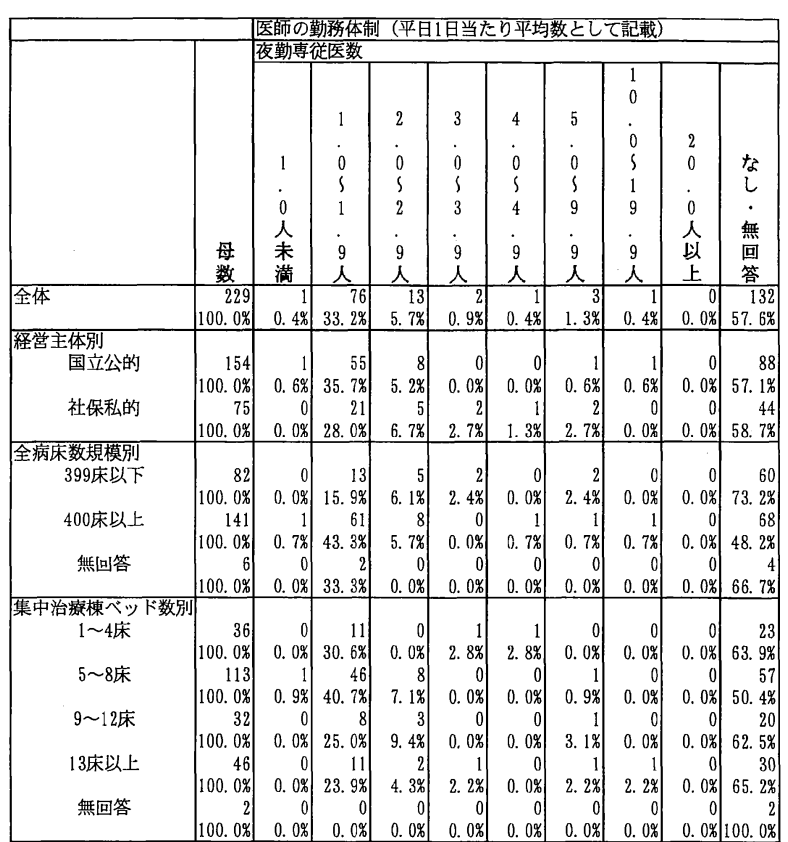

図25

6）夜勤医師数：研修医（專従）（図 26）

の $19.7 \%$ で，専従医師のそれより低い。

研修医（専従）が夜勤をしている集中治療棟は全体

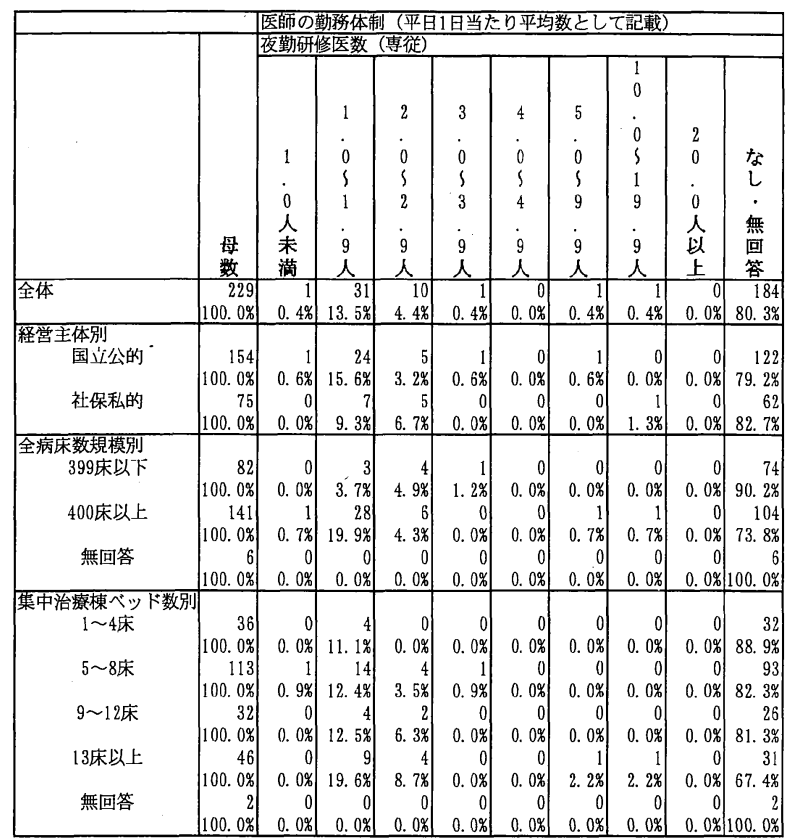




\section{F．看護に関する調査}

\section{1）看護職員の配置}

a. 専従看護婦（士）配置の有無と配置人数（図 27）

(1) 229 施設中 189 (82.5\%) が専従看護婦（士）を配 置していると回答した。一方では, 配置していない, な いし無回答が 40 （17.5\%）施設ある。専従者を配置し ている施設は, 社保私的, 399 床以下の病院に対して, 国公立, 400 床以上の病院に多い傾向がある。

集中治療ベッド数別には, $1 \sim 4$ 床の規模の集中治 療棟に専従者を置く病院が少なく $(63.9 \%), 5 \sim 8$ 床 ならびに 9 〜 12 床の規模では約 $84 \%, 13$ 床以上では $95.7 \%$ の病院が尃従者を配置している。

(2) 専従者有りの場合, 集中治療ベッド1床当たりの 配置人数は, $3.0 \sim 3.9$ 人が 57 (30.2\%) 施設, $2.0 \sim$
2.9 人が 51 (27.0\%)，1.0 1.9 が 47 (24.9\%) であり, $1 \sim 3.9$ 人を合わせると $82.1 \%$ と大多数を占める。経 営主体別には大きな差はないが, 病床規模別には, 399 床以下で $1.0 \sim 1.9$ 人が 28 (45.9\%) 施設, 400 床以上 では 3.0 〜 3.9 人が 48 (38.4\%) と多いのが特徴的であ る。集中治療棟ベッド数別には, $1 \sim 4$ 床規模で 3.0 〜 3.9 人が $47.8 \%$ と最も多く, $5 \sim 8$ 床規模では $2.0 \sim 2.9$ 人 $(29.5 \%)$ と $3.0 \sim 3.9$ 人 (34.7\%) が多いのに対し て, $9 \sim 12$ 床規模では $1.0 \sim 1.9$ 人が $37.0 \%, 2.0 \sim 2.9$ 人と $3.0 \sim 3.9$ 人がそれぞれ $29.6 \%$ と看護職員の 1 床 当たりの配置数が 2 名未満である施設が 3 分の 1 を超 えている。この傾向は 13 床以上の施設で更に顕著化 し， $59.0 \%$ の施設において 1 床当たりの配置数が 2 名 以下である。

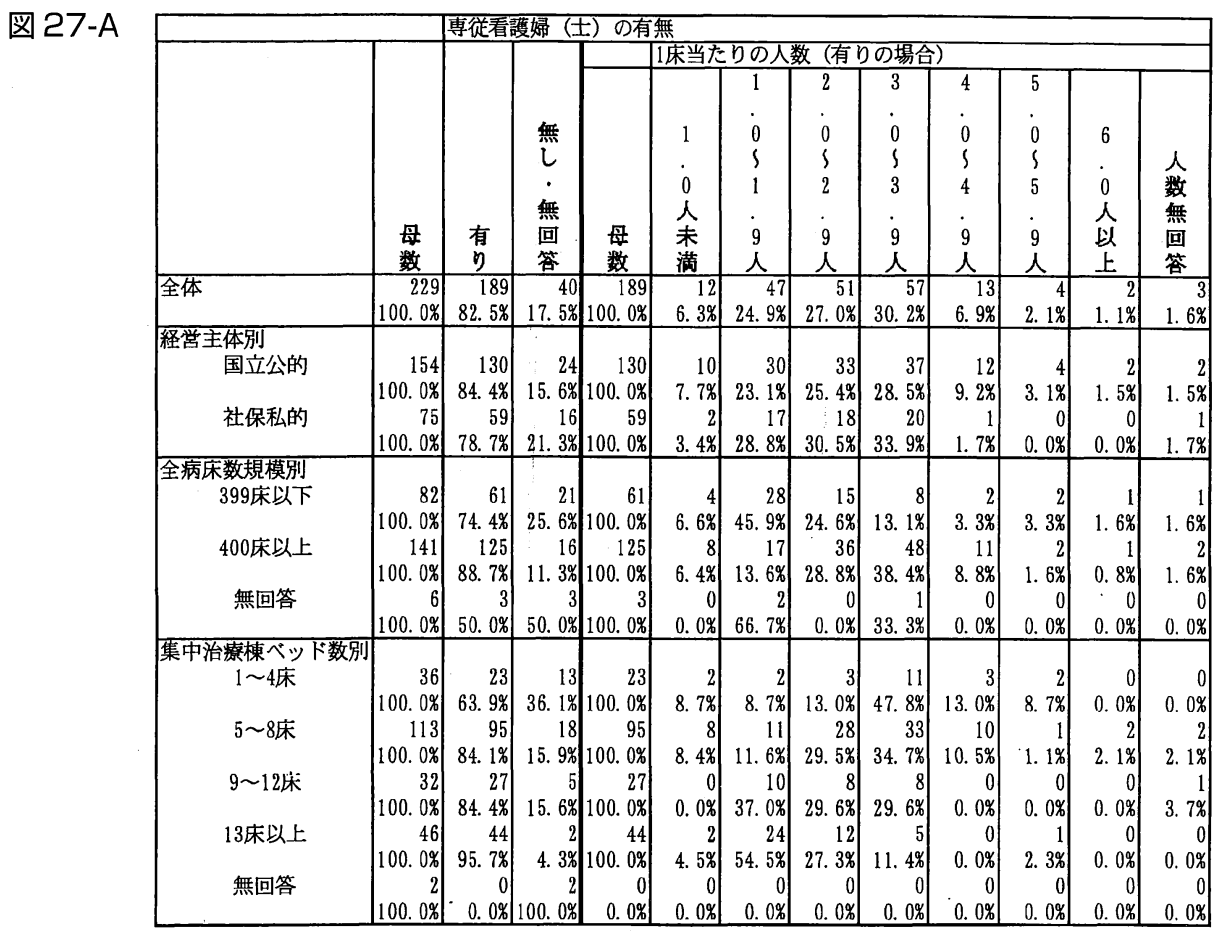

図27-B

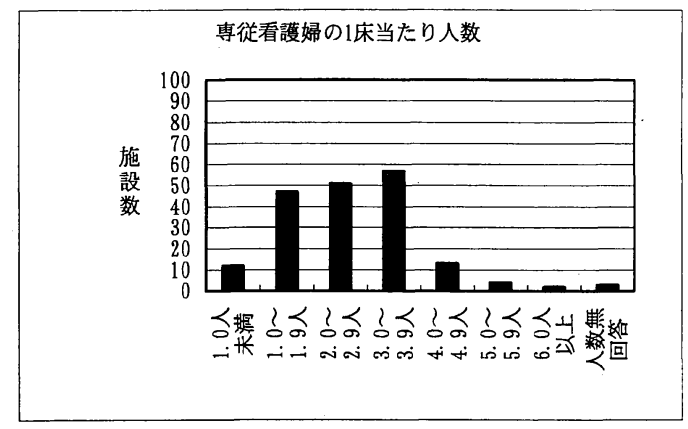


b. 理想的な専従看護婦（士）配置数（図 28）

1 床当たり何人の看護婦（士）を配置するのが理想 的かとの問いに対して 187 施設から回答が得られた。 実際の配置数と比較するため母数を 187 とすると, 2 名 以上の配置数を理想的とした施設は，145（77.5\%）で ある。そのうち 3.0 〜 3.9 人をあげたのが 49 (26.2\%)， $2.0 \sim 2.9$ 人が $44(23.5 \%), 4.0 \sim 4.9$ 人が $34(18.2 \%)$ 施設ある。これに対して，1床当たり $1.0 〜 1.9$ 人を理 想的配置数とする施設が 35 (18.7\%) あり，1.0 人以下 とする回答も 7 (3.7\%) ある。これらを比較すると，実

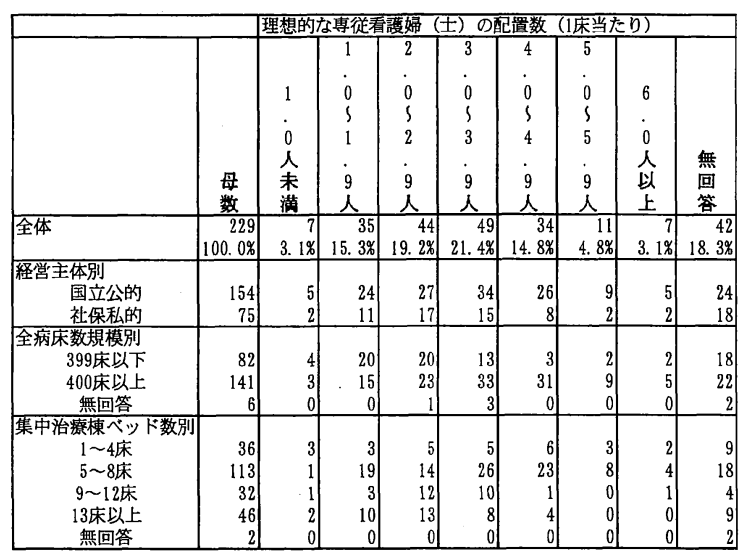

図28-A

本文中は回答数 187 を母数とした。

\section{c. 兼務看護婦（士）の兼務先}

兼務看護婦（士）を有する場合その本務先は，外科 16 , 救急部 11 , 手術室 8 , 内科 - 循環器科 - 呼吸器科 6 , 各科・各病棟 6 , 麻醉科 3 , 放射線科 2 , 小児科 1 , その他 4 である。その他と回答した 4 施設の本務先内 訳は, 心カテ室, 人工透析室，クリーンルーム，リハ ビリ各 1 である。
際の専属看護婦（士）配置数は 1 床当たり 1.9 人以下 で理想とする配置数より多く $(31.2 \%$ 対 $22.4 \%), 4.0$ 人 以上でははるかに少ない $(10.1 \%$ 対 $27.8 \%)$ ことがわか る。経営主体別には特に理想的な配置数に傾向はみら れない。全病床規模別には, 399 床以下の病院で理想 的な配置数との回答が $1.0 \sim 2.9$ 人に多いのに対し, 400 床以上の病院では $3.0 \sim 4.9$ 人を理想的とする回答が多 い。集中治療棟ベッド数別には, 9 ～ 12 床の施設で 2.0 ～ 2.9 人, $3.0 \sim 3.9$ 人に回答が集中している傾向があ る。

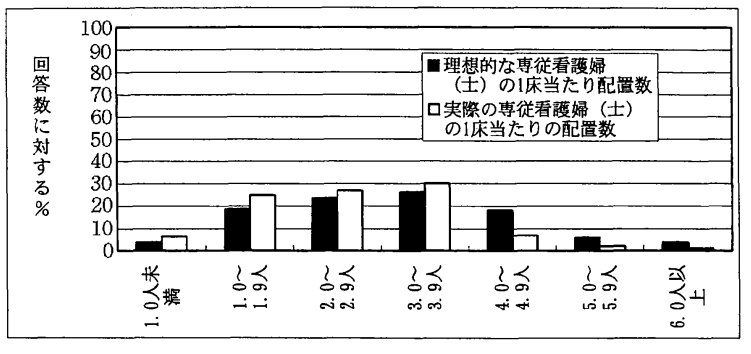

図 28-B

母数 (回答数) : $\square 189$ 施設,

187 施設.

d. 専従看護婦（士）内訳：正看護婦（士）数と准看 護婦数（(図 29）

正看護婦（士）と准看護婦の各施設毎の比率は不明 であるが, 準看護婦を配置していると答えた施設は 53 (23.1\%)，総配置数は 170 人である。1施設当たりで最 も多い准看護婦の配置数は 8 人で，その施設数は 5 で ある。全体として集中治療棟への准看護婦の配置数は 少ない。
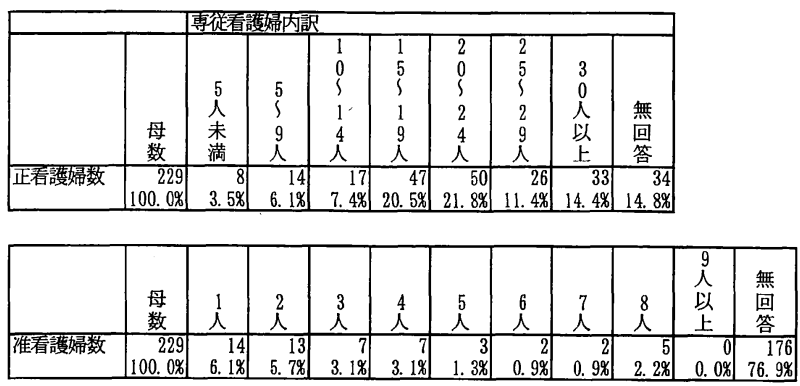

図29 
e. 看護助手，クラークの配置数（図 30）

看護助手を 1 人以上配置していると答えたのは 146 (63.3\%) 施設である。無回答が $36.7 \%$ と多いのは, 設 問に0人が無かったために無回答の中に無しが含まれ たものと考えられる。クラークを有しているのは 56 (24.5\%) 施設で，そのほとんどは 1 人である。看護助 手と同様，無回答に無しが含まれるものと思われる。
経営主体別には, 社保私的病院の方が看護助手につい てもクラークについても配置している割合が国立公的 病院より高い。集中治療棟ベッド数別には, 9 〜 12 床, 13 床以上のベッド数の施設で看護助手, クラークとも 配置率が高い。また，13床以上では 2 人以上の看護助 手を有している施設が多い。

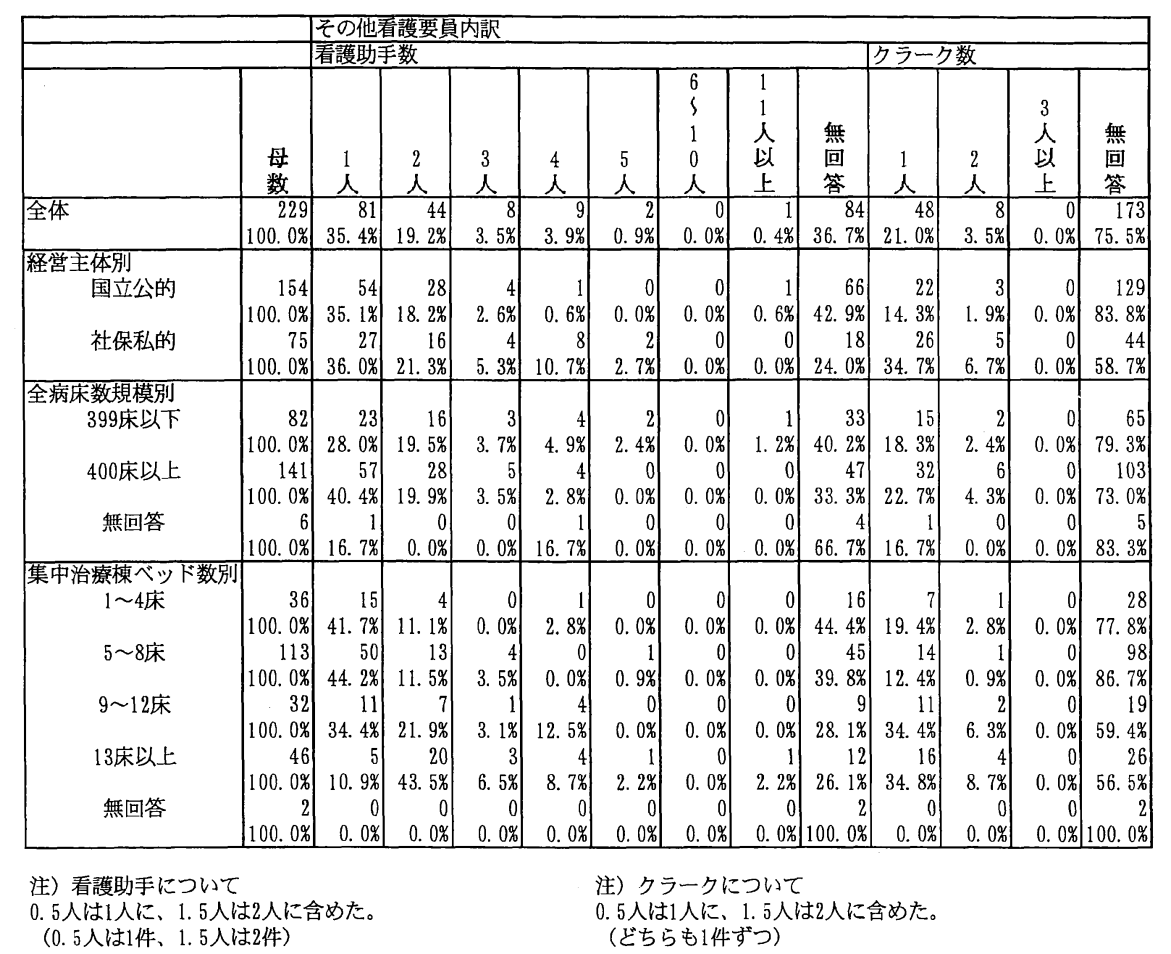

図 30

f. 看護婦（士）の集中治療棟勤務年数別分布（図 31）

専従看護婦（士）の集中治療部における勤務年数別 の人数分布は, 5 年未満の 1 年毎をみると, いずれも
$1 \sim 4$ 人に多く分布する。経験年数に伴う特別な傾向 はみられない。勤務年数 5 年以上については, $10 \sim 14$ 人が配置されている施設が 36 (15.7\%) と最も多い。

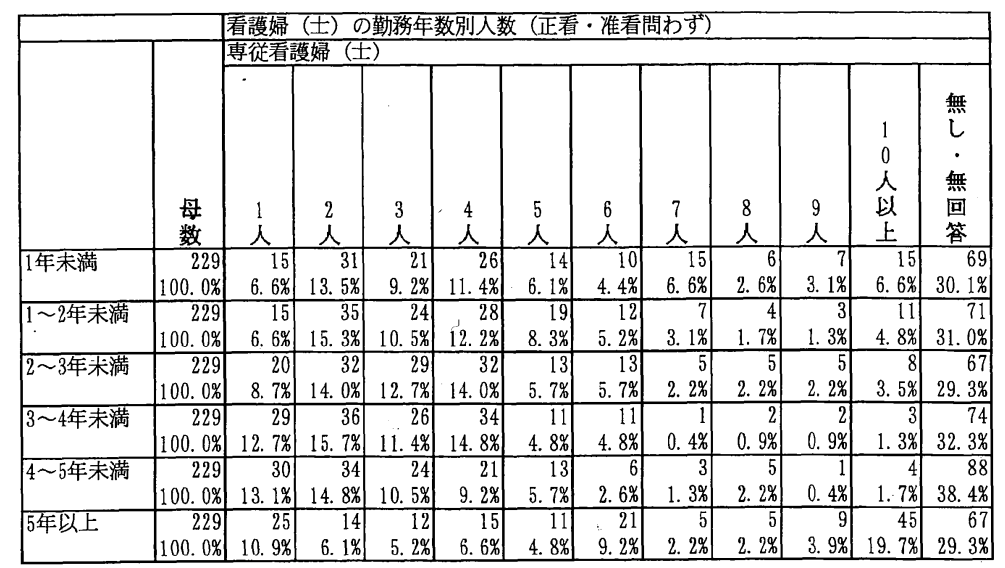

図 31 
g. 看護婦（士）の勤務年数別平均人数（図 32）

専従看護婦 (士), 兼務看護婦（士）とも, 経験年数 別平均人数に特に偏りはみられない。 5 年以上の平均
では, 国立公的病院, 400 床以上の病院, 13 床以上の 集中治療棟において経験 5 年以上の専従看護婦 (士) が 多い傾向がみられる。

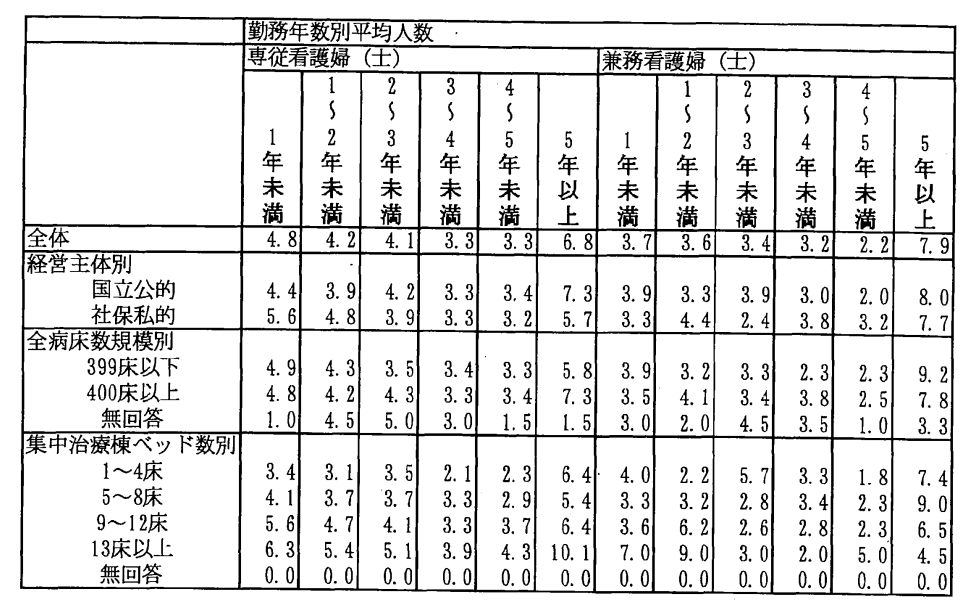

図 32

h. 一般病棟での経験年数別分布（図 33）

(1) $152(66.4 \%)$ の施設が一般病棟での経験のない看 護婦（士）を有している。そのうち約 60\% (90 施設) において 5 人以上の病棟未経験者が配属されている。 10 人以上の未経験者が配属されている施設は 50 (32.9\%) ある。病棟未経験者の配属されている施設数
は, 400 床以上の病院において 399 床以下に比して高 率である。

(2)一般病棟での経験のない看護婦 (士) が 152 の施 設で集中治療棟に配属されている一方で, 一般病棟で の経験を有する看護婦（士）もそれぞれの経験年数ご とに 1 ～ 4 人づつ配属されている。

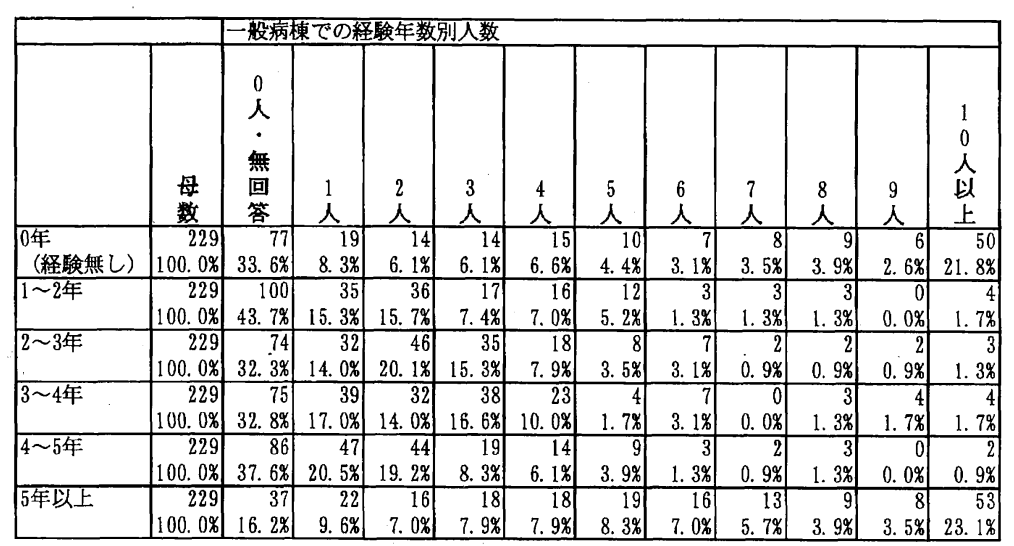

注）集中治療部に勤務する前の経験年数で、集中治療部勤務が2度目の看護婦は除外

図33 


\section{2）看護業務}

a. 申し送り所用時間（図 34）

入室患者 1 人当たりの申し送りに要する平均時間 は, 5〜6分が48 (21.0\%) 施設と最も多い。101 (44.1\%) の施設が 2 分から 6 分未満で申し送りを行っている。
一方，10 分以上かける施設が $62 （ 27.0 \% ）$ ある。集中 治療棟ベッド数別には，13 床以上の施設では 10 分以 上の申し送りを行う施設は, 12 床以下のベッド数の施 設に比して少ない。

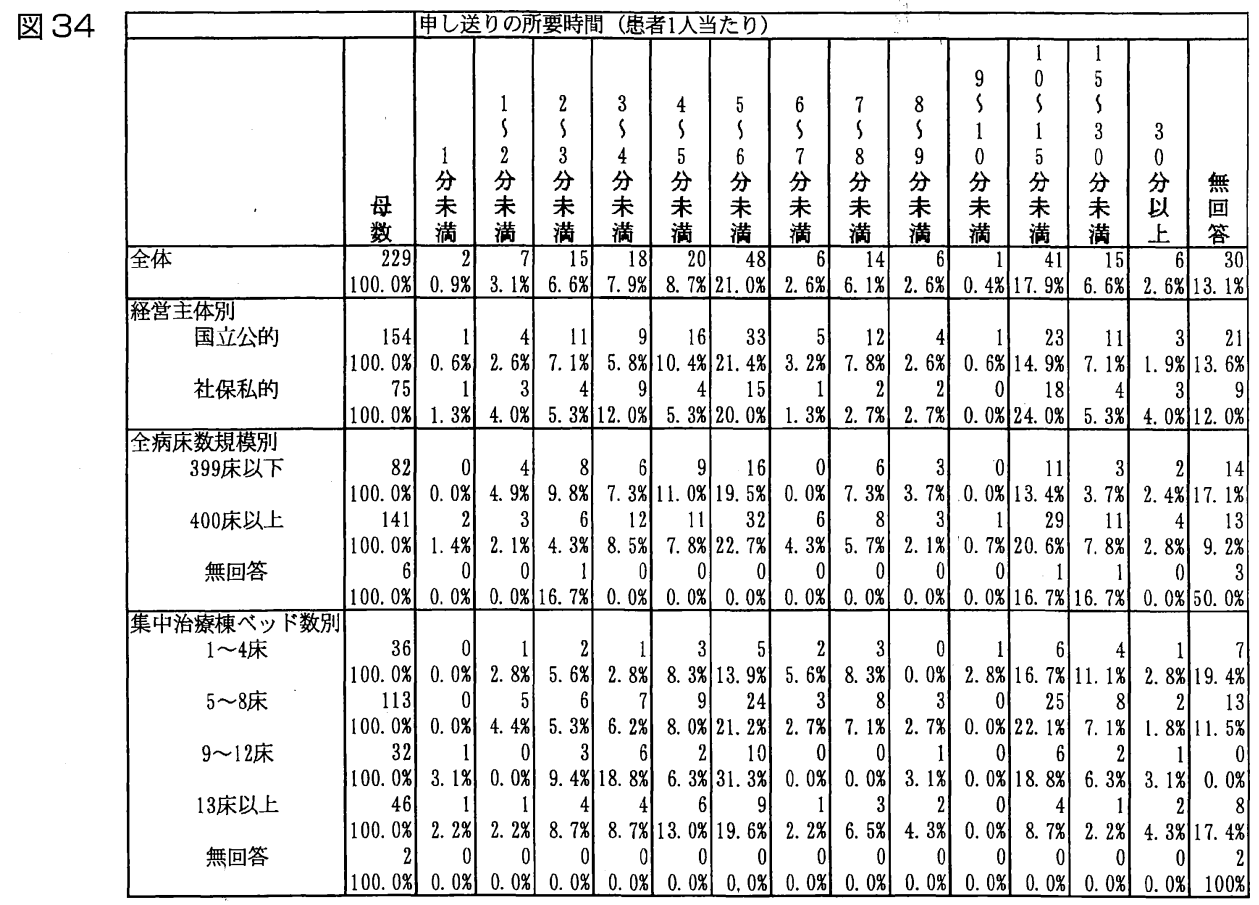

b. 看護体制（図 35）

受け持ち制の看護体制を取っている施設が 85 (37.1\%) で最も多い。ついで，チームナーシング 45 (19.7\%)，プライマリーナーシングと他の方式 の併用 34 (14.8\%), 複数の方式の併用 31 (13.5\%), その他 13 (5.7\%) であるが，その他の内容の多く は複数方式の併用である。併用の内容をみると, 受け持ち制とチームナーシングの併用が最も多 い。したがって，この両者が集中治療看護の主流 をなしていることがわかる。

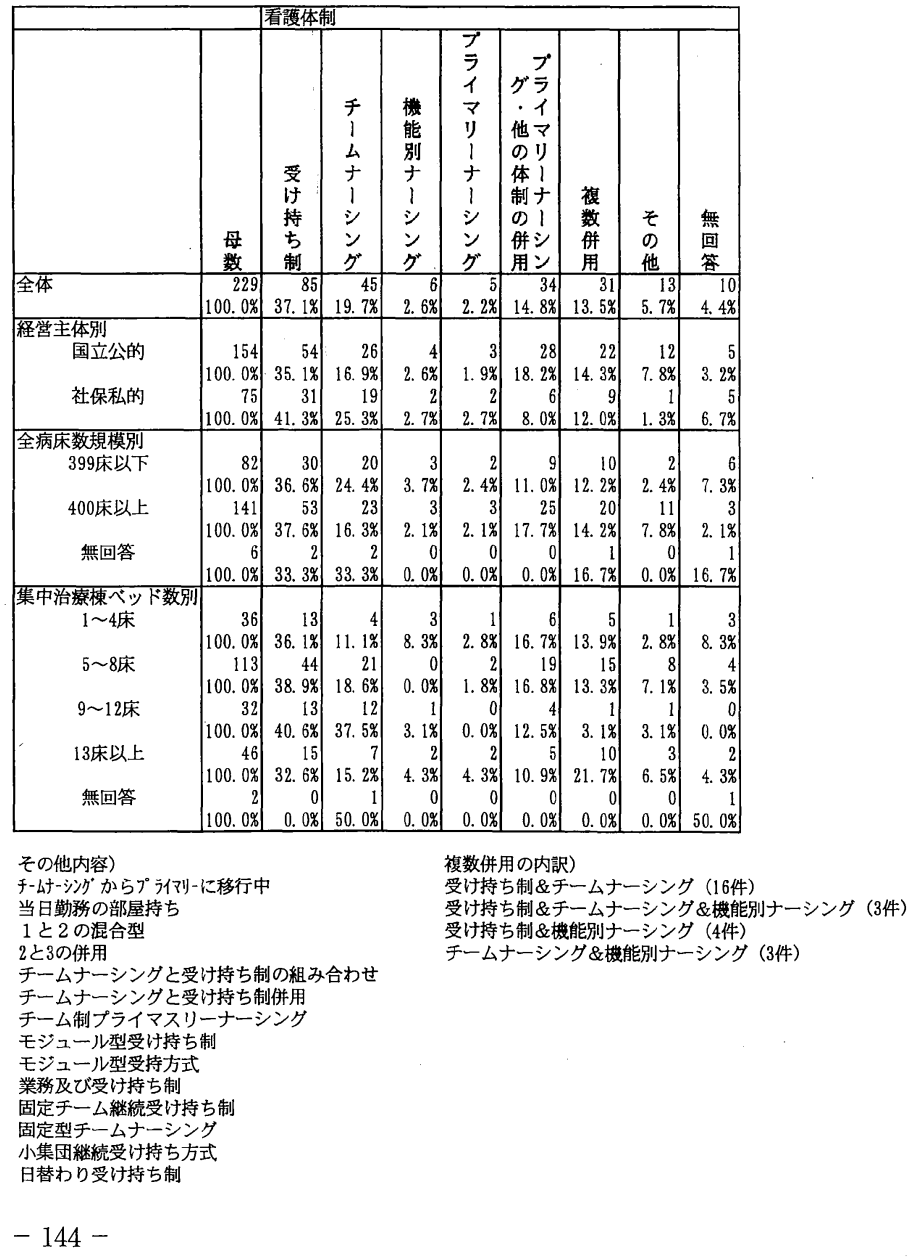


3）勤務体制

a. 勤務の交代制（図 36）

211 (92.1\%) の施設で 3 交代制勤務が実施されてい
る。少数ながら 2 交代制をとっているのは，社保私的 病院, 399 床以下の病院である。

\begin{tabular}{|c|c|c|c|c|c|c|}
\hline & & 交代制 & & & & \\
\hline & 贯 & $\begin{array}{l}3 \\
\text { 交 } \\
\text { 代 } \\
\text { 制 }\end{array}$ & $\begin{array}{l}2 \\
\frac{1}{x} \\
\text { 垈 } \\
\text { 制 }\end{array}$ & $\begin{array}{l}\text { 覆 } \\
\text { 数 } \\
\text { 回 } \\
\text { 答 }\end{array}$ & $\begin{array}{l}z \\
\sigma \\
\text { 他 }\end{array}$ & $\begin{array}{l}\text { 無 } \\
\text { 回 } \\
\text { 答 }\end{array}$ \\
\hline 全体 & $\begin{array}{r}229 \\
100.0 \% \\
\end{array}$ & $\begin{array}{r}211 \\
92.1 \% \\
\end{array}$ & $\begin{array}{r}7 \\
3.1 \% \\
\end{array}$ & $\begin{array}{r}3 \\
1.3 \% \\
\end{array}$ & $\begin{array}{r}1 \\
0.4 \% \\
\end{array}$ & 3. $1 \%$ \\
\hline 経営主体別 & & & & & & \\
\hline $\begin{array}{l}\text { 国立公的 } \\
\text { 社保私的 }\end{array}$ & $\begin{array}{r}154 \\
100.0 \% \\
75 \\
100.0 \% \\
\end{array}$ & $\begin{array}{r}148 \\
96.1 \% \\
63 \\
84.0 \% \\
\end{array}$ & $\begin{array}{r}0 \\
0.0 \% \\
7 \\
9.3 \% \\
\end{array}$ & $\begin{array}{r}2 \\
1.3 \% \\
1 \\
1.3 \% \\
\end{array}$ & $\begin{array}{r}1 \\
0.6 \% \\
0 \\
0.0 \%\end{array}$ & $\begin{array}{r}3 \\
1.9 \% \\
4 \\
5.3 \% \\
\end{array}$ \\
\hline 全病床数規模別 & & & & & & \\
\hline 399床以下 & $\begin{array}{r}82 \\
100.0 \%\end{array}$ & $\begin{array}{r}68 \\
82.9 \%\end{array}$ & $\begin{array}{r}6 \\
7.3 \%\end{array}$ & 2. $\begin{array}{r}2 \\
\text { 2. }\end{array}$ & $\begin{array}{r}1 \\
1.28\end{array}$ & $\begin{array}{r}5 \\
6.1 \%\end{array}$ \\
\hline 400 床以上 & $\begin{array}{r}141 \\
100\end{array}$ & $\begin{array}{r}137 \\
97 \quad 2 \%\end{array}$ & $\begin{array}{r}1 \\
0 \\
7 \%\end{array}$ & $\begin{array}{r}1 \\
0.7\end{array}$ & $\begin{array}{r}0 \\
0\end{array}$ & $\begin{array}{r}2 \\
4 \%\end{array}$ \\
\hline 無回答 & $\begin{array}{r}6 \\
100.0 \% \\
\end{array}$ & $\begin{array}{r}6 \\
100.0 \%\end{array}$ & $\begin{array}{r}0 \\
0.0 \% \\
\end{array}$ & $\begin{array}{r}0 \\
0.0 \% \\
\end{array}$ & $\begin{array}{r}0 \\
0.0 \%\end{array}$ & $\begin{array}{r}0 \\
0.0 \%\end{array}$ \\
\hline 集中治療棟ベット数別 & & & & & & \\
\hline 1 4床 & 36 & & 2 & 0 & 1 & \\
\hline $5 \sim 8$ 床 & $\mid \begin{array}{r}10000 \\
113\end{array}$ & $\begin{array}{r}86.10 \\
105\end{array}$ & $\begin{array}{r}6 \% \\
3\end{array}$ & $\begin{array}{r}0 \% \\
2\end{array}$ & & \\
\hline & $100.0 \%$ & $92.9 \%$ & 2. $7 \%$ & $1.8 \%$ & $0.0 \%$ & 2. $7 \%$ \\
\hline $9 \sim 12$ 床 & & 31 & 1 & 0 & 0 & \\
\hline & $100.0 \%$ & $96.9 \%$ & $3.1 \%$ & $0.0 \%$ & $0.0 \%$ & $0 \%$ \\
\hline 13 床以上 & & 43 & 1 & 1 & 0 & 1 \\
\hline 無回答 & {$\left[\begin{array}{c}100.08 \\
2\end{array}\right]$} & 93. 5\% & 2. $2 \%$ & 2. $2 \%$ & $0.0 \%$ & 2. $2 \%$ \\
\hline & $100.0 \%$ & $50.0 \%$ & $0.0 \%$ & $0.0 \%$ & $0.0 \%$ & $50.0 \%$ \\
\hline
\end{tabular}

\section{の他内容}

庠出制

変則 3 交代制

早出勤務7-15:45 1名/日、途出13-21:45 1名/日

図 36 
b. 勤務交代時刻

(1) 日勤勤務（図 37）の開始時刻は，8:30〜 9:00 が $137(59.8 \%)$ 施設と最も多く, ついで $8: 00 \sim 8$ : 30 が 69 (30.1\%) で，8:00〜 9:00 が 89.9\%を占め
る。日勤の終了時刻は, $17: 00 〜 17: 30$ が 125 (54.6\%) と多い。ついで $16: 30 \sim 17: 00,16: 00 \sim 16: 30$ と 続き，16：00〜 17：30のあいだに 194（84.7\%）の施 設で日勤が終了する。

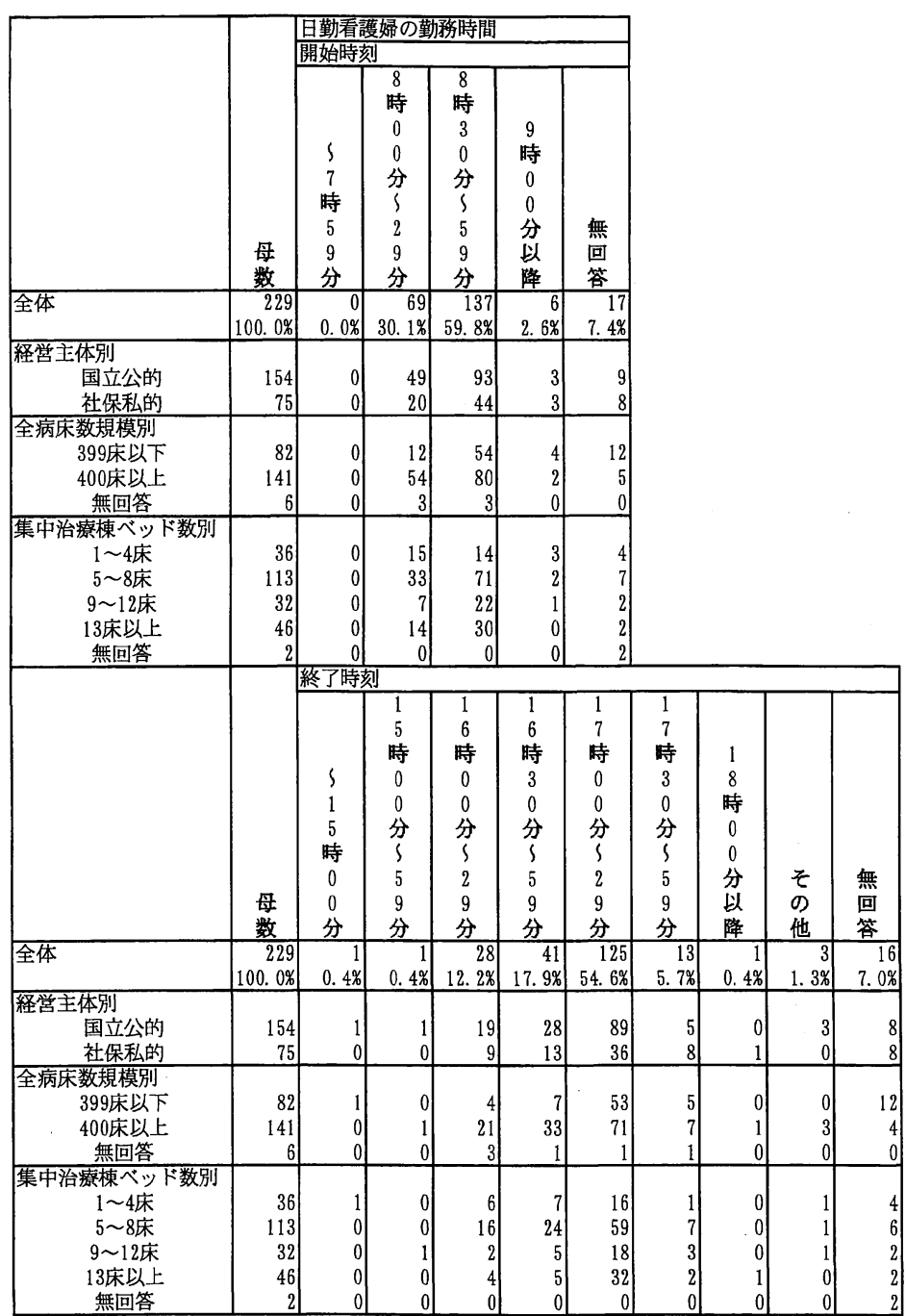

図 37 
(2) 準夜勤務（図 38）の開始は，16:30〜 17:00 が $102(44.5 \%)$ 施設, $16: 00 \sim 16: 30$ が $70(30.6 \%)$ 施 設である。日勤の終了時刻と比べて, 準夜勤務の開始
時刻は少し前後に広がっいる。終了時刻は，0：00〜 $1: 30$ の間に広がって抢り, 最も多いのは $1: 00 \sim 1$ : 30 の 91 （39.7\%）である。

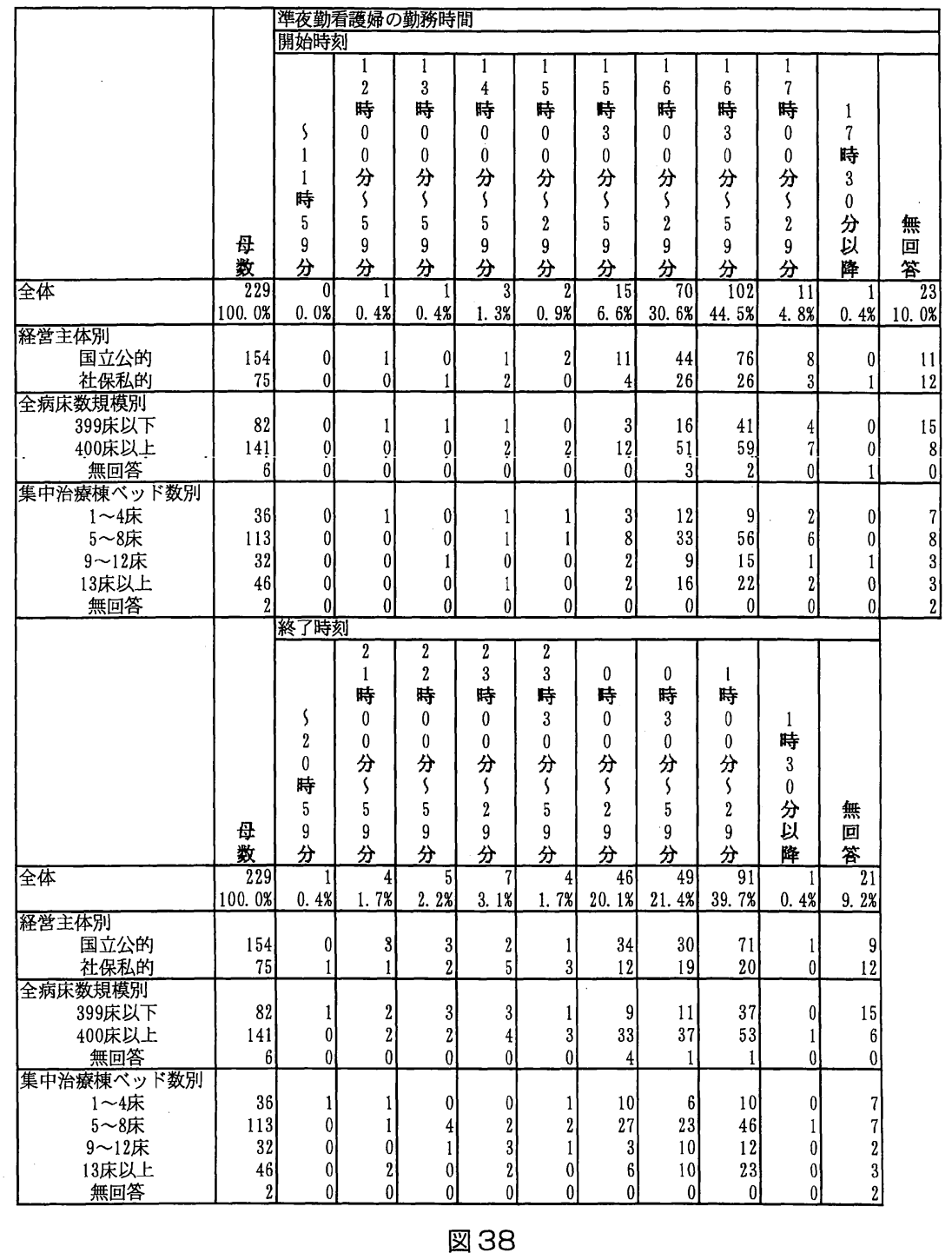


(3) 深夜勤務（図 39）の開始は, $0: 30 \sim 1: 00$ が 94 である。他は $0: 00$ 以前の開始が多いが, $1: 00 \sim 1$ :

(41.0\%) で最も多く,ついで $0: 00 〜 0: 30$ の $78(34.1 \%) \quad 30$ に 9 施設が深夜勤務を開始している。

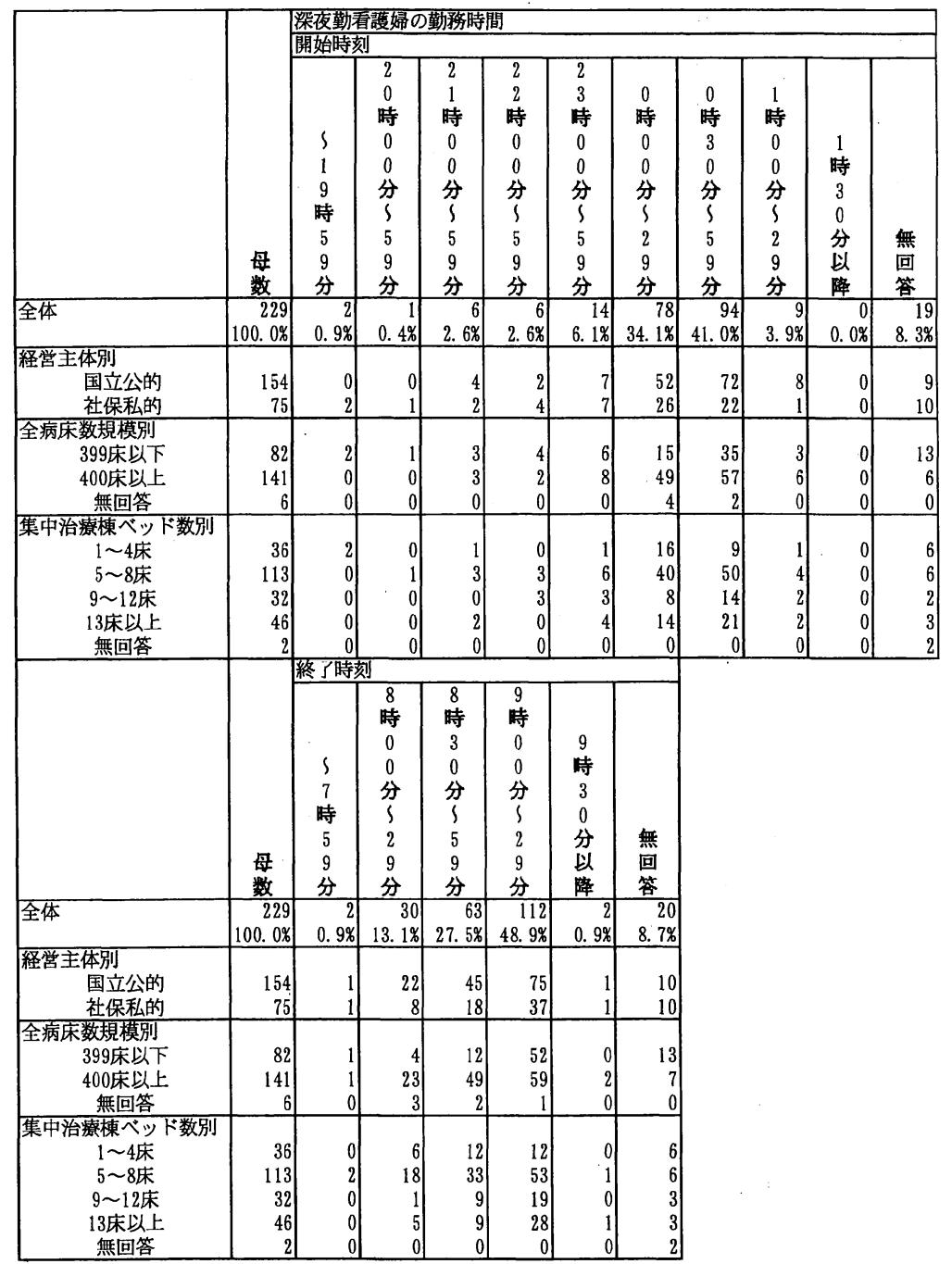

図39 
c. 看護婦 (士) 1 人当たりの受け持ち患者数（図 40）

(1) 日勤時間帯の看護婦（士） 1 人当たりの受け持ち 患者数は，1.0～ 2.0 未満が 81 (35.4\%)，2.0 3.0 未 満が $92(40.2 \%)$ で， 1 人当たり患者 3 人未満の施設 が 179 （78.2\%）を占める。経営主体別, 全病床規模別 には受け持ち患者数に差はない。集中治療ベッド数別 には， $9 \sim 12$ 床，13 床以上の施設で 8 床以下の施設 に比べ，受け持ち患者数が多い傾向がある。

(2)·(3) 準夜勤務（図 41），深夜勤務（図 42）の時間 帯では，それぞれ約半数の施設で看護婦（士） 1 人当 たりの受け持ち患者数が 3.0 人未満である。しかし，あ と半数の施設では準夜, 哚夜の受け持ち患者数が 3 人 以上になっている。経営主体別, 全病床規模別には, 国 立公的, 400 床以上の病院で 3.0 人未満の比率が高い。 集中治療ベッド数別には， $1 \sim 4$ 床， $5 \sim 8$ 床の施設 で 3.0 人未満の受け持ち患者数が多いのに対して, 9 12 床, 13 床以上では 3.0 人以上を受け持つ施設が多い。

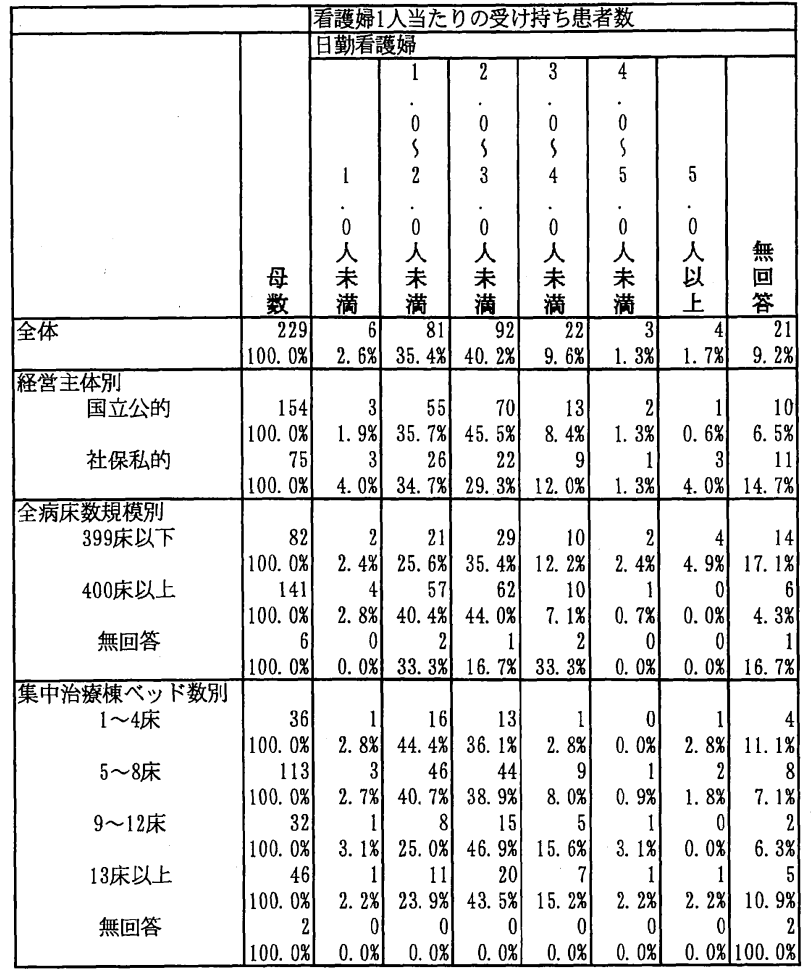

図 40

\begin{tabular}{|c|c|c|c|c|c|c|c|c|c|c|c|c|}
\hline & & 看護婦1 & 当た & の受け & 夯思 & 数 & & & & & & \\
\hline & & 準夜勤着 & 蒦婦 & & & & & & & & & \\
\hline & $\begin{array}{l}\text { 母 } \\
\text { 数 }\end{array}$ & $\begin{array}{l}1 \\
\dot{0} \\
\text { 人 } \\
\text { 未 } \\
\text { 満 }\end{array}$ & $\begin{array}{l}1 \\
\dot{0} \\
5 \\
2 \\
. \\
0 \\
\text { 人 } \\
\text { 未 } \\
\text { 満 }\end{array}$ & $\begin{array}{l}2 \\
\dot{0} \\
5 \\
3 \\
\dot{0} \\
\text { 人 } \\
\text { 未 } \\
\text { 満 }\end{array}$ & $\begin{array}{l}3 \\
\dot{0} \\
3 \\
4 \\
\dot{0} \\
\text { 人 } \\
\text { 未 }\end{array}$ & $\begin{array}{l}4 \\
\dot{0} \\
0 \\
S \\
5 \\
\dot{0} \\
0 \\
\text { 人 } \\
\text { 未 } \\
\text { 満 }\end{array}$ & $\begin{array}{l}5 \\
\dot{0} \\
5 \\
6 \\
\dot{0} \\
\text { 人 } \\
\text { 未 } \\
\text { 満 }\end{array}$ & $\begin{array}{l}6 \\
. \\
0 \\
5 \\
7 \\
\dot{0} \\
\text { 人 } \\
\text { 未 } \\
\text { 満 }\end{array}$ & $\begin{array}{l}7 \\
\dot{0} \\
5 \\
8 \\
\dot{0} \\
\text { 人 } \\
\text { 未 } \\
\text { 満 }\end{array}$ & $\begin{array}{l}8 \\
\dot{0} \\
0 \\
5 \\
1 \\
0 \\
. \\
0 \\
人 \\
\text { 未 } \\
\text { 满 }\end{array}$ & $\begin{array}{l}1 \\
0 \\
0 \\
0 \\
\text { 人 } \\
\text { 上 }\end{array}$ & $\begin{array}{l}\text { 無 } \\
\text { 回 } \\
\text { 答 }\end{array}$ \\
\hline 全体 & $\begin{array}{r}229 \\
100.0 \% \\
\end{array}$ & $\begin{array}{r}4 \\
1.7 \% \\
\end{array}$ & $\begin{array}{r}6 \\
2.6 \% \\
\end{array}$ & $\begin{array}{r}103 \\
45.0 \% \\
\end{array}$ & $\begin{array}{r}41 \\
17.9 \% \\
\end{array}$ & $\begin{array}{r}25 \\
10.9 \% \\
\end{array}$ & $\begin{array}{r}12 \\
5.2 \% \\
\end{array}$ & $\begin{array}{r}2 \\
0.9 \% \\
\end{array}$ & $\begin{array}{r}5 \\
2.2 \% \\
\end{array}$ & $\begin{array}{r}3 \\
1.3 \%\end{array}$ & $\begin{array}{r}3 \\
1.3 \%\end{array}$ & $\begin{array}{r}25 \\
10.9 \%\end{array}$ \\
\hline $\begin{array}{r}\text { 経営主体別 } \\
\text { 国立公的 } \\
\text { 社保私的 }\end{array}$ & $\begin{array}{r}154 \\
100.0 \% \\
75 \\
100.0 \%\end{array} \mid$ & $\begin{array}{r}3 \\
1.9 \% \\
1 \\
1.3 \%\end{array}$ & $\begin{array}{r}2 \\
1.3 \% \\
4 \\
5.3 \%\end{array}$ & $\begin{array}{r}83 \\
53.9 \% \\
20 \\
26.7 \%\end{array}$ & $\begin{array}{r}23 \\
\text { 14. } 9 \% \\
18 \\
24.0 \%\end{array}$ & $\begin{array}{r}18 \\
\text { 11. } 7 \% \\
7 \\
9.3 \%\end{array}$ & $\begin{array}{r}8 \\
5.2 \% \\
4 \\
5.3 \%\end{array}$ & $\begin{array}{r}2 \\
1.3 \% \\
0 \\
0.0 \%\end{array}$ & $\begin{array}{r}2 \\
1.3 \% \\
3 \\
4.0 \%\end{array}$ & $\begin{array}{r}3 \\
1.9 \% \\
0 \\
0.0 \%\end{array}$ & $\begin{array}{r}0 \\
0.0 \% \\
3 \\
4.0 \%\end{array}$ & $\begin{array}{r}10 \\
6.5 \% \\
15 \\
20.0 \%\end{array}$ \\
\hline $\begin{array}{r}\text { 全病床数規模別 } \\
399 \text { 床以下 } \\
400 \text { 床以上 } \\
\text { 無回答 }\end{array}$ & $\begin{array}{r}82 \\
100.0 \% \\
141 \\
100.0 \% \\
6 \\
100.0 \%\end{array} \mid$ & $\begin{array}{r}2 \\
2.4 \% \\
2 \\
1.4 \% \\
0 \\
0.0 \%\end{array}$ & $\begin{array}{r}1 \\
1.2 \% \\
5 \\
3.5 \% \\
0 \\
0.0 \%\end{array}$ & $\begin{array}{r}21 \\
25.6 \% \\
80 \\
56.7 \% \\
2 \\
33.3 \%\end{array}$ & $\begin{array}{r}11 \\
\text { 13. } 4 \% \\
29 \\
20.6 \% \\
1 \\
\text { 16. } 7 \%\end{array}$ & $\begin{array}{r}13 \\
\text { 15. } 9 \% \\
12 \\
\text { 8. } 5 \% \\
0 \\
0.0 \%\end{array}$ & $\begin{array}{r}9 \\
11.0 \% \\
2 \\
1.4 \% \\
1 \\
16.7 \%\end{array}$ & $\begin{array}{r}2 \\
2.4 \% \\
0 \\
0.0 \% \\
0 \\
0.0 \%\end{array}$ & $\begin{array}{r}2 \\
2.4 \% \\
3 \\
2.1 \% \\
0 \\
0.0 \%\end{array}$ & $\begin{array}{r}1 \\
1.2 \% \\
1 \\
0.7 \% \\
1 \\
16.7 \%\end{array} \mid$ & $\begin{array}{r}3 \\
3.7 \% \\
0 \\
0.0 \% \\
0 \\
0.0 \%\end{array}$ & $\begin{array}{r}17 \\
20.7 \% \\
7 \\
5.0 \% \\
1 \\
16.7 \%\end{array}$ \\
\hline 集中治療棟ベッド数号 & & & & & & & & & & & & \\
\hline 1 4 庆 & $\begin{array}{r}36 \\
100.0 \%\end{array}$ & 2. $\begin{array}{r}1 \\
\end{array}$ & 8. $3 \%$ & $\begin{array}{r}21 \\
58.3 \%\end{array}$ & 5. $6 \%$ & 2. $8 \%$ & 2. $8 \%$ & $\begin{array}{r}0 \\
0.0 \%\end{array}$ & $\begin{array}{r}0 \\
0.0 \%\end{array}$ & 2. $8 \%$ & 2. $8 \%$ & 13. $\begin{array}{r}5 \\
\end{array}$ \\
\hline 5〜8床 & $\begin{array}{r}113 \\
100.0 \%\end{array}$ & $\begin{array}{r}1 \\
0.9 \%\end{array}$ & $\begin{array}{r}1 \\
0.9 \%\end{array}$ & $\begin{array}{r}67 \\
59.3 \%\end{array}$ & $\begin{array}{r}21 \\
\text { 18. } 6 \%\end{array}$ & $\begin{array}{r}5 \\
\text { 4. } 4 \%\end{array}$ & $\begin{array}{r}2 \\
1.8 \%\end{array}$ & $\begin{array}{r}2 \\
1.8 \%\end{array}$ & $\begin{array}{r}2 \\
1.8 \%\end{array}$ & $\begin{array}{r}1 \\
0.9 \%\end{array}$ & $\begin{array}{r}2 \\
1.8 \%\end{array}$ & $\begin{array}{r}9 \\
8.0 \%\end{array}$ \\
\hline $9 \sim 12$ 床 & $\left.\begin{array}{r}32 \\
100.0 \%\end{array}\right]$ & 6. $3 \%$ & $\begin{array}{r}1 \\
3.1 \%\end{array}$ & $\begin{array}{r}7 \\
21.9 \%\end{array}$ & $\begin{array}{r}8 \\
25.0 \%\end{array}$ & $\begin{array}{r}8 \\
25.0 \%\end{array}$ & 9. $4 \%$ & $\begin{array}{r}0 \\
0.0 \%\end{array}$ & $\begin{array}{r}0 \\
0.0 \%\end{array}$ & $\begin{array}{r}0 \\
0.0 \%\end{array}$ & $\begin{array}{r}0 \\
0.0 \%\end{array}$ & 9. $4 \%$ \\
\hline $\begin{array}{l}13 \text { 床以上 } \\
\text { 無回答 }\end{array}$ & $\begin{array}{r}46 \\
100.0 \% \\
2 \\
100.0 \%\end{array} \mid$ & $\begin{array}{r}0 \\
0.0 \% \\
0 \\
0.0 \%\end{array}$ & 2. $\begin{array}{r}1 \\
2 \% \\
0 \\
0.0 \%\end{array}$ & $\begin{array}{r}7 \\
15.2 \% \\
0 \\
0.0 \%\end{array}$ & $\begin{array}{r}10 \\
21.7 \% \\
0 \\
0.0 \%\end{array}$ & $\begin{array}{r}11 \\
23.9 \% \\
0 \\
0.0 \%\end{array}$ & $\begin{array}{r}6 \\
13.0 \% \\
0 \\
0.0 \%\end{array}$ & $\begin{array}{r}0 \\
0.0 \% \\
0 \\
0.0 \%\end{array}$ & $\begin{array}{r}3 \\
6.5 \% \\
0 \\
0.0 \%\end{array}$ & $\begin{array}{r}1 \\
2.2 \% \\
0 \\
0.0 \%\end{array}$ & $\begin{array}{r}0 \\
0.0 \% \\
0 \\
0.0 \%\end{array}$ & $\begin{array}{r}6 \\
13.0 \% \\
2 \\
100.0 \%\end{array}$ \\
\hline
\end{tabular}




\begin{tabular}{|c|c|c|c|c|c|c|c|c|c|c|c|c|}
\hline & & \multicolumn{11}{|c|}{ 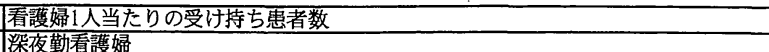 } \\
\hline & $\begin{array}{l}\text { 母 } \\
\text { 数 } \\
\end{array}$ & $\begin{array}{l}0 \\
\text { 人 } \\
\text { 尃 } \\
\end{array}$ & \begin{tabular}{l|}
1 \\
$j$ \\
0 \\
5 \\
2 \\
0 \\
0 \\
人 \\
未 \\
满 \\
\end{tabular} & \begin{tabular}{|l|}
2 \\
0 \\
0 \\
3 \\
3 \\
0 \\
0 \\
人 \\
未满 \\
\end{tabular} & 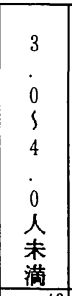 & \begin{tabular}{|l|}
4 \\
0 \\
0 \\
5 \\
5 \\
0 \\
0 \\
人 \\
未 \\
满 \\
\end{tabular} & $\begin{array}{l}5 \\
j \\
0 \\
5 \\
6 \\
j \\
0 \\
\text { 人 } \\
\text { 满 } \\
\end{array}$ & \begin{tabular}{l|}
6 \\
. \\
0 \\
5 \\
7 \\
$\dot{0}$ \\
0 \\
人 \\
满 \\
\end{tabular} & $\begin{array}{l}7 \\
j \\
0 \\
j \\
8 \\
\dot{0} \\
0 \\
\text { 人 } \\
\text { 满 } \\
\end{array}$ & \begin{tabular}{l|}
8 \\
0 \\
0 \\
3 \\
1 \\
0 \\
0 \\
0 \\
人 \\
未 \\
満 \\
\end{tabular} & $\begin{array}{l}1 \\
0 \\
\text { 人 } \\
\text { 以 } \\
\text { 上 } \\
\end{array}$ & $\begin{array}{l}\text { 無 } \\
\text { 睘 } \\
\text { 答 }\end{array}$ \\
\hline 全体 & $\begin{array}{r}229 \\
100.0 \% \\
\end{array}$ & $\begin{array}{r}3 \\
1.3 \% \\
\end{array}$ & $\begin{array}{r}5 \\
2.2 \% \\
\end{array}$ & $\begin{array}{r}106 \\
46.3 \% \\
\end{array}$ & $\begin{array}{r}42 \\
18.3 \% \\
\end{array}$ & $\begin{array}{r}24 \\
10.5 \% \\
\end{array}$ & $\begin{array}{r}11 \\
4.8 \% \\
\end{array}$ & $\begin{array}{r}4 \\
1.7 \% \\
\end{array}$ & $\begin{array}{r}5 \\
2.2 \% \\
\end{array}$ & & $\begin{array}{r}3 \\
1.3 \% \\
\end{array}$ & $\begin{array}{r}23 \\
10.0 \%\end{array}$ \\
\hline $\begin{array}{l}\text { 経営主体别 } \\
\text { 国立公的 } \\
\text { 社保私的 }\end{array}$ & $\begin{array}{r}154 \\
100.0 \% \\
75 \\
100.0 \%\end{array}$ & $\begin{array}{r}3 \\
1.9 \% \\
0 \\
0.0 \%\end{array}$ & $\left.\begin{array}{r}0.6 \% \\
4 \\
5.3 \%\end{array}\right]$ & \begin{tabular}{|r|}
84 \\
$54.5 \%$ \\
22 \\
$29.3 \%$ \\
\end{tabular} & \begin{tabular}{r|}
23 \\
$14.9 \%$ \\
19 \\
$25.3 \%$ \\
\end{tabular} & \begin{tabular}{r|}
17 \\
$11.0 \%$ \\
7 \\
$9.3 \%$
\end{tabular} & $\begin{array}{r}8 \\
5.2 \% \\
3 \\
4.0 \%\end{array}$ & $\begin{array}{r}3 \\
1.96 \\
1 \\
1.3 \%\end{array}$ & \begin{tabular}{r|r}
2 \\
$1.3 \%$ \\
3 \\
$4.0 \%$
\end{tabular} & $\begin{array}{r}3 \\
1.9 \% \\
0 \\
0.0 \%\end{array}$ & $\begin{array}{r}0 \\
0.0 \% \\
3 \\
\text { 4. } 0 \%\end{array}$ & $\begin{array}{r}10 \\
6.5 \% \\
13 \\
17.3 \%\end{array}$ \\
\hline $\begin{array}{c}\text { 全病床数規模別 } \\
\text { 3996木 } \\
\text { 400床以上 } \\
\text { 無回答 }\end{array}$ & $\begin{array}{r}82 \\
100.0 \% \\
141 \\
100.0 \% \\
6 \\
100.0 \% \\
\end{array}$ & \begin{tabular}{r|r}
1 & \\
1. $2 \%$ \\
2 \\
1. $4 \%$ \\
0 \\
$0.0 \%$
\end{tabular} & \begin{tabular}{r|r}
2 \\
$2.4 \%$ \\
3 \\
$2.1 \%$ \\
0 \\
$0.0 \%$ \\
\end{tabular} & $\begin{array}{r}21 \\
25.6 \% \\
83 \\
58.9 \% \\
2 \\
33.3 \% \\
\end{array}$ & $\begin{array}{r}13 \\
\text { 15. } 9 \% \\
28 \\
\text { 19. } 9 \% \\
1 \\
16 \\
16.7 \% \\
\end{array}$ & $\begin{array}{r}13 \\
15.9 \% \\
11 \\
7.8 \% \\
0 \\
0.0 \% \\
\end{array}$ & $\begin{array}{r}8 \\
9.8 \% \\
2 \\
1.4 \% \\
1 \\
16.7 \%\end{array}$ & \begin{tabular}{r|}
3 \\
$3.7 \%$ \\
1 \\
$0.7 \%$ \\
0 \\
$0.0 \%$
\end{tabular} & $\begin{array}{r}2 \\
2.4 \% \\
3 \\
2.1 \% \\
0 \\
0.0 \% \\
\end{array}$ & $\begin{array}{r}1 \\
1.2 \% \\
1 \\
0.7 \% \\
1 \\
16.7 \%\end{array}$ & \begin{tabular}{r|r}
3 \\
3. $7 \%$ \\
0 \\
$0.0 \%$ \\
0 \\
$0.0 \%$
\end{tabular} & $\begin{array}{r}15 \\
18.3 \% \\
7 \\
5.0 \% \\
1 \\
16.7 \%\end{array}$ \\
\hline $\begin{array}{c}\text { 集中治裺棟ベッド数別 } \\
1 \text { 嘛 } \\
5 \sim 8 \text { 床 } \\
9 \sim 12 \text { 床 } \\
13 \text { 床以上 } \\
\text { 無回答 }\end{array}$ & $\begin{array}{r}36 \\
100.0 \% \\
113 \\
100.0 \% \\
32 \\
100.0 \% \\
46 \\
100.0 \% \\
2 \\
100.0 \%\end{array}$ & \begin{tabular}{r|r}
1 \\
$2.8 \%$ \\
1 \\
$0.9 \%$ \\
1 \\
$3.1 \%$ \\
0 \\
$0.0 \%$ \\
0 \\
$0.0 \%$
\end{tabular} & $\begin{array}{r}2 \\
5.6 \% \\
0 \\
0.0 \% \\
2 \\
6.3 \% \\
1 \\
2.2 \% \\
0 \\
0.0 \% \\
\end{array}$ & $\begin{array}{r}23 \\
63.9 \% \\
68 \\
60.2 \% \\
7 \\
21.9 \% \\
8 \\
17.4 \% \\
0 \\
0.0 \% \\
\end{array}$ & $\begin{array}{r}2 \\
\text { 5. } 6 \% \\
22 \\
\text { 19. } 5 \% \\
8 \\
25.0 \% \\
10 \\
21.7 \% \\
0 \\
0.0 \% \\
\end{array}$ & \begin{tabular}{r|r|}
1 \\
$2.8 \%$ \\
5 \\
$4.4 \%$ \\
8 \\
$25.0 \%$ \\
10 \\
$21.7 \%$ \\
0 \\
$0.0 \%$ \\
\end{tabular} & $\begin{array}{r}1 \\
\text { 2. } 8 \% \\
2 \\
\text { 1. } 8 \% \\
3 \\
\text { 9. } 4 \% \\
5 \\
\text { 10. } 9 \% \\
0 \\
0.0 \% \\
\end{array}$ & \begin{tabular}{r|r}
0 \\
$0.0 \%$ \\
2 \\
$1.8 \%$ \\
0 \\
$0.0 \%$ \\
2 \\
$4.3 \%$ \\
0 \\
$0.0 \%$
\end{tabular} & \begin{tabular}{r|}
0 \\
$0.0 \%$ \\
2 \\
$1.8 \%$ \\
0 \\
$0.0 \%$ \\
3 \\
$6.5 \%$ \\
0 \\
$0.0 \%$
\end{tabular} & $\begin{array}{r}2.8 \% \\
1 \\
0.9 \% \\
0 \\
0.0 \% \\
1 \\
2.2 \% \\
0 \\
0.0 \%\end{array}$ & \begin{tabular}{r|r}
$2.8 \%$ \\
1 \\
$0.9 \%$ \\
1 \\
3. $1 \%$ \\
0 \\
$0.0 \%$ \\
0 \\
$0.0 \%$ \\
\end{tabular} & $\begin{array}{r}11.1 \% \\
9 \\
8.0 \% \\
2 \\
6.3 \% \\
6 \\
13.0 \% \\
2 \\
100.0 \%\end{array}$ \\
\hline
\end{tabular}

図 42 
4）看護婦（士）と医師の連携（図 43）

集中治療棟に打いて看護婦（士）と医師とが毎日合 同カンファレンスを行うのは 48 (21.0\%) のみである。 時々行うが 88 (38.4\%) あるが，行わない施設が約 30 \%ある。集中治療部看護管理者（婦長）と医師との間
で患者のケアに関して情報交換を毎日行うのは 102 (44.5\%)，受け持ちナースと医師の間で毎日行うのは $174 （ 76.0 \%)$ である。患者看護に関してのナースと医 師の連携は，主として受け持ちナースと担当医師の間 で毎日または不定期的に行われている。

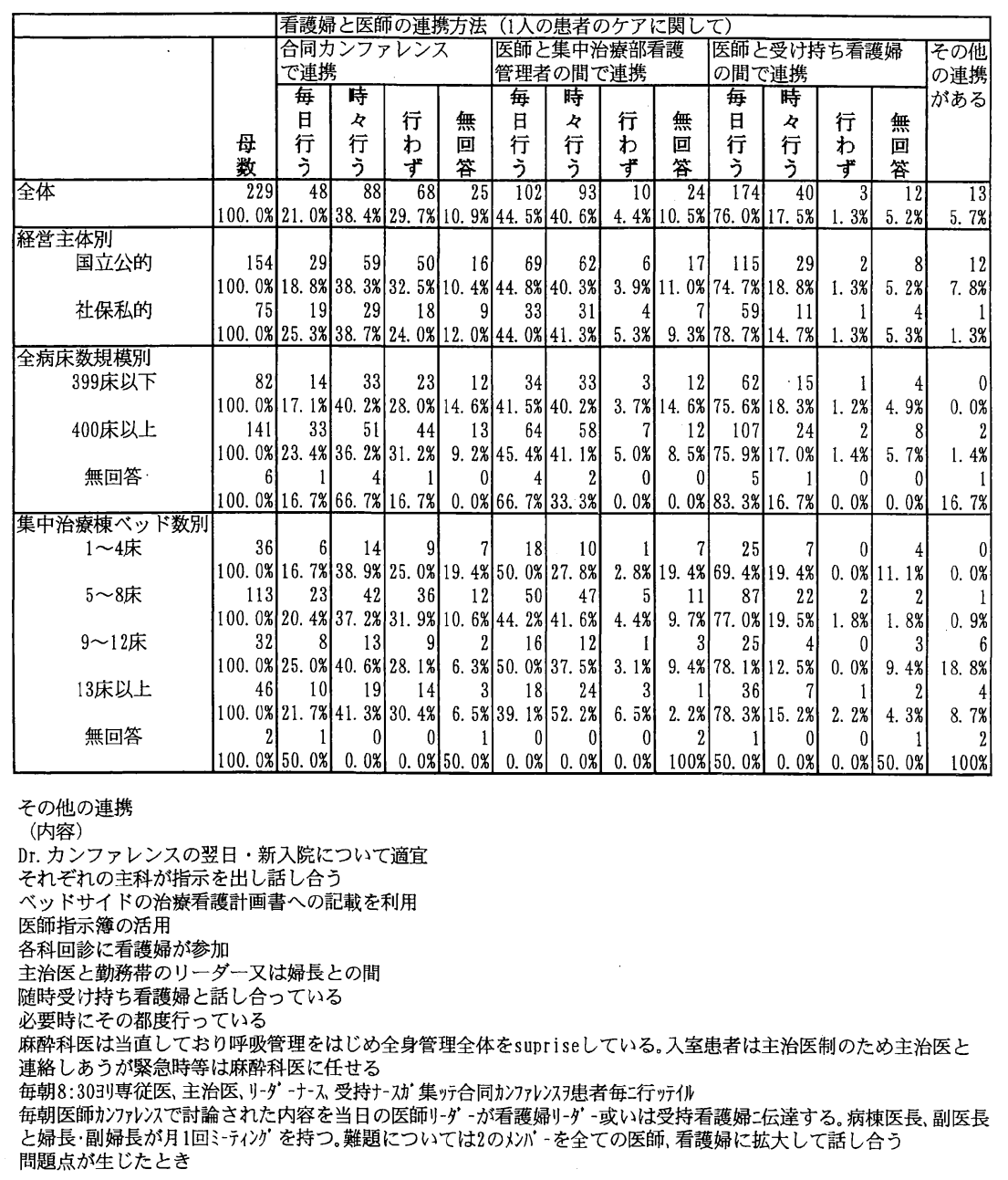

図43 
図 44



心マッサージ（胸骨圧迫式）

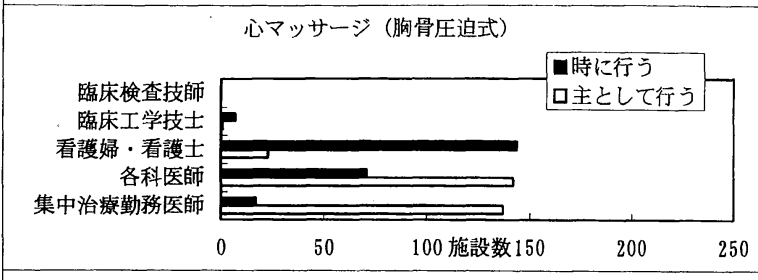

電気的除細動
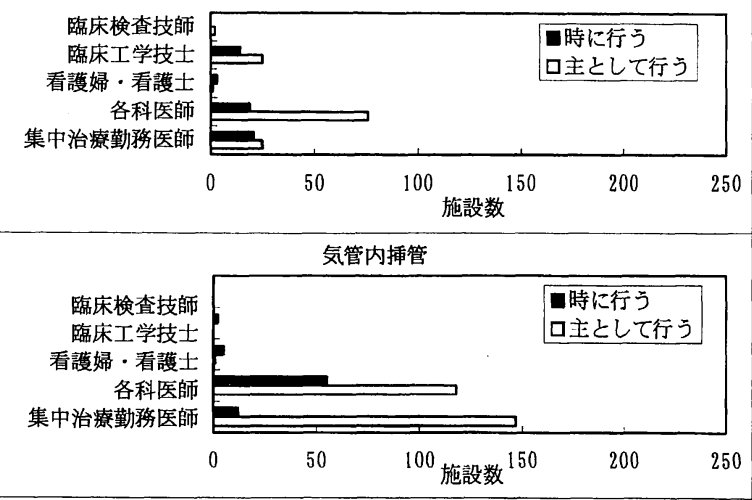

図 45

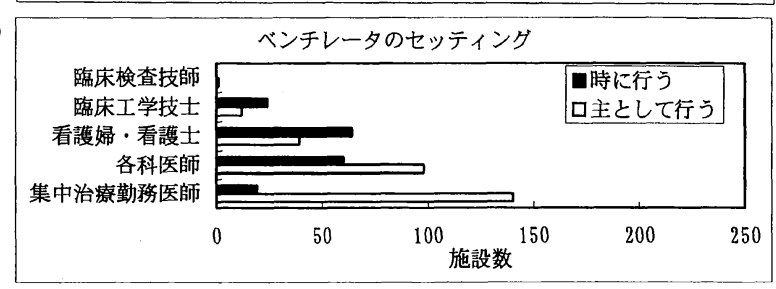

図46
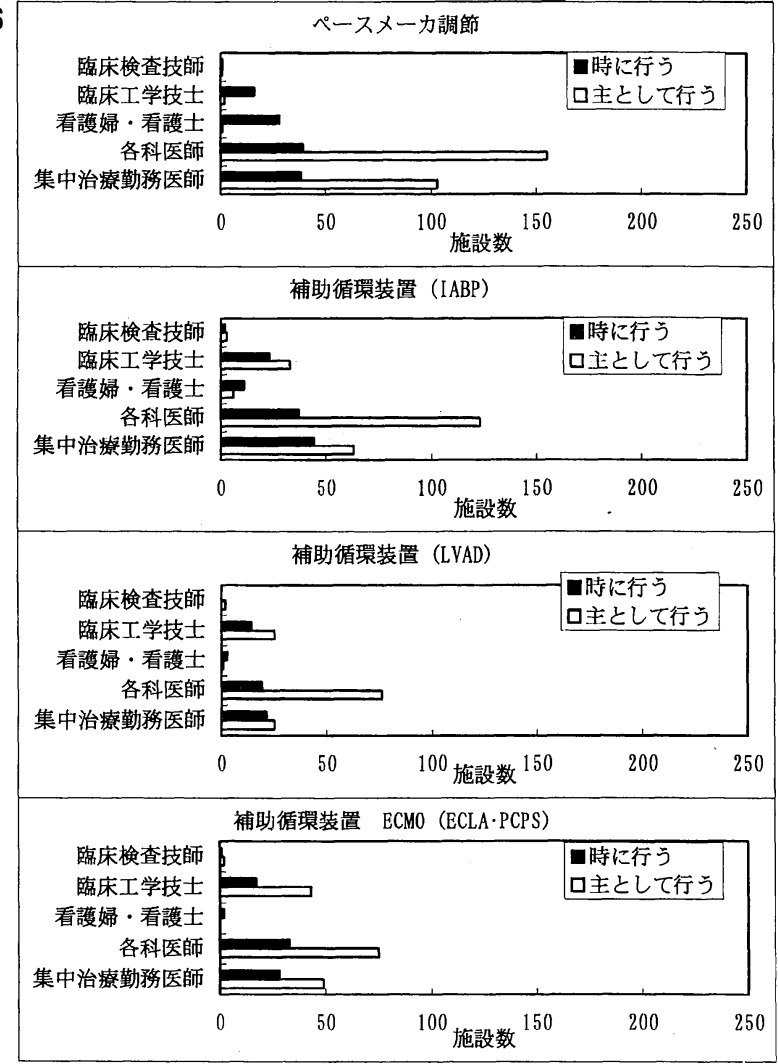

\section{G. 医療従事者の診療上の役割分担}

医師 (集中治療部医師, 各科医師, 専門医), 看護婦・ 看護士 (ナース), 臨床工学技士, 臨床検查技師の診察 上の役割分担を調査した。

1) 治療行為（救命処置, 呼吸管理, 循環管理, 血液 浄化法)

a. 救命処置（図 44）

救命処置について,バッグによる人工換気 (B) なら びに胸骨圧迫式心マッサージ (C) を主として行うとの 回答は, 集中治療部医師 $(B ： 140, C ： 137)$ と各科医 師（B：125，C：142）についてほほ同数である。しか し, 時に行うとの答えは集中治療部医師に少なく $(\mathrm{B}$ ： $16, C ： 17)$ 各科医師に多い $(B: 79, C ： 71)$ 。ナース は両手技とも時に行うとの回答が多い（B：150, C : 144）が, 少数ながら主として行うとの答えもある(B： 9, C：23)。臨床工学技士も時に行うとの答えが少数み られる。

電気的心除細動については，集中治療部医師（134） ならびに各科医師（139）が主として行う施設が多い。 ナースが主として行うとの回答は 3 施設である。

気管内挿管は，上と同様に集中治療部医師（147）と 各科医師（118）が主として行うとしている。ナースが 主として行うと答えたのが 1 施設である。

b. 呼吸管理（図 45）

ベンチレータのセッティングについては，集中治療 部医師が主として行うと答えた施設 (140) が救命処置 の場合とほほ同数であるが, 各科医師が主として行う とする回答（98）は救命処置に比して低い。ナースが 主として行うとの回答（39）は救命処置の場合に比し て多い。

c. 循環管理（図 46）

ペースメーカーの調節は，各科医師（155），集中治 療部医師（103）が主として行うという回答が多い。

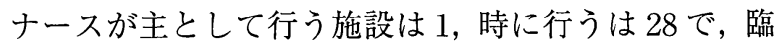

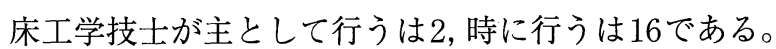

補助循環装置の装着とセッティングについては, IABP，LVAD， ECMO (ECLA, PCPS) とも各科医 師が主として行っている施設が多い（それぞれ，123， $76 ， 75) 。 I A B P ， の$ 場合は，ついで集中治療部医師 (63)，臨床工学技士（33）の順であるが，LVAD なら びに ECMO については, 集中治療部医師と臨床工学 技士が主として行う施設数がほぼ同数である。 


\section{d．血液浄化法（図 47）}

血液透析ならびに血液滤過透析装置のセッティン グ・装着に関しては, 臨床工学技士の役割が最も大き い。血液透析については, 主として臨床工学技士が行 う施設が 102 に達する。ついで集中治療部医師 77 , 各 科医師 53 ，ナース 28 といずれも臨床工学技士を下回 る。血液滤過透析については, 集中治療部医師 92 , 臨 床工学技士 88 , 各科医師 52 , ナース 25 の順である。 血漿交換についても, 主として臨床工学技士が行うが 87 施設, ついで集中治療部医師 77 , 各科医師 62 , ナー ス 20 である。

2）モニタリング (図 48)

ベッドサイドモニター (210) ならびにセントラルモ ニター(170)ともナースが主として監視を行う施設が 圧倒的に多い。集中治療部医師が主としてモニター監 視を行う施設はベッドサイド（91），セントラル（68） あるが，各科医師は時に行うとの回答の方が多い。少 数ではあるが, 臨床工学技士（ベッドサイド : 9 , セン トラル：3）, 臨床検查技師（ベッドサイド：2，セント ラル：1）が主としてモニター監視を行うとの回答もあ る。

3）検 查 (図 49)

a. 検体検査（集中治療部内で行うもの）

血球計数を臨床検查技師が主として行う施設は 88 で最も多く，集中治療部医師が主として行うとの回答 は39 と半数に満たない。各科医師，ナースの場合はと もに 20 施設である。血液ガス分析は，集中治療部医師 （102），各科医師（82）ついでナース（63）が主として 行う施設が，臨床検查技師が主として行う施設を上 回っている。電解質の場合は, 臨床検查技師 77 , 集中 治療部医師 74 ，ナース 54 と後二者が主として行う施 設が血球検査より多い。これらに対して, 電解質以外 の血液生化学（101）, 血液凝固検査（113）, 浸透圧測 定（99），尿生化学検查（112）では臨床検查技師が主 として行う施設が多く，医師・ナースが主として行う 施設は少ない。ただし，尿量測定（216）·と尿比重測定 （180）はナースによって行われている施設がほとんど である。

b. 生理機能検査（図 50）

スパイロメトリーは主として集中治療部医師が行う との回答が多く，心電図（12 誘導）は主としてナース （102）ついで臨床検查技師（80）が記録している施設 が多い。

中心静脈圧については，カテーテル挿入を主として 行うのが集中治療部医師（137），各科医師（133）があ るが，測定については 181 の施設でナースが主として

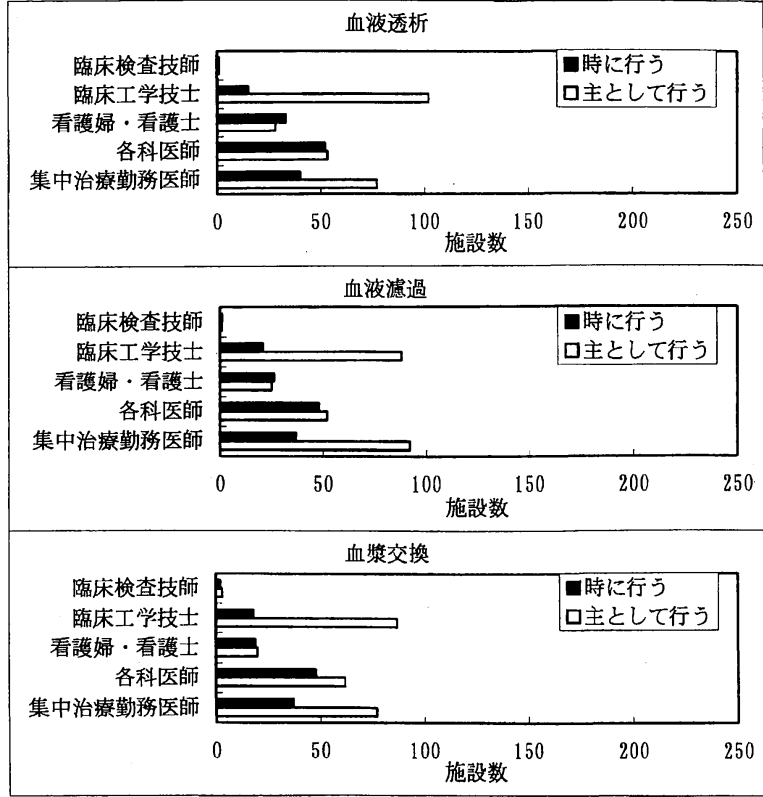

図 47

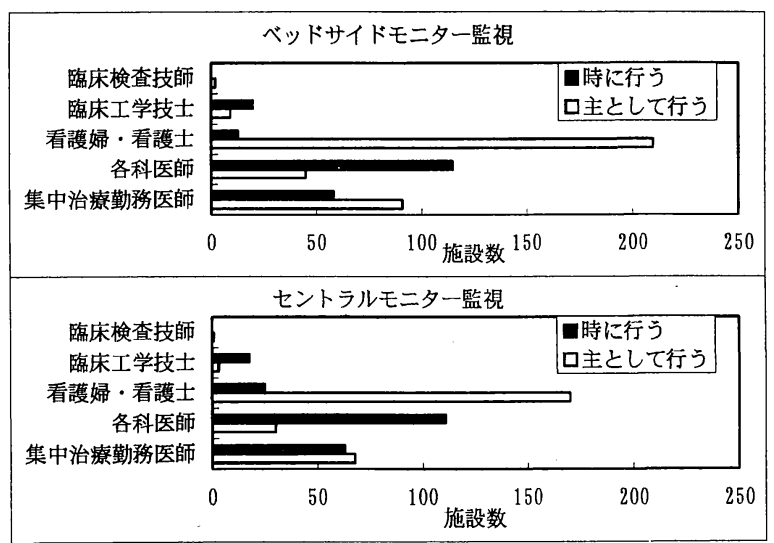

図 48

行っている。集中治療部医師（55），各科医師 (42) が 主として行うとの回答もあるが，数は少ない。少数で はあるが臨床工学技士（4）が行うとの回答もある。

肺動脈圧について，カテーテル挿入は中心静脈圧と 同様である。測定は,ナースが主として行う施設 (107) が最も多いが, 集中治療部医師（83）, 各科医師（78）, 臨床工学技士（10）が主として行う施設が中心静脈圧 測定に比して多い。

熱希釈法による心拍出量測定については，集中治療 部医師（124）と各科医師（119）が主として行ってお り，ナース（5）が主として行うという回答は少ない。 脳波記録ならびに脳誘発反応検査（聴性脳幹反応を 含む）については，臨床検查技士が主として行ってい る施設がそれぞれ 166, 117 と大半を占める。臨床工学 技士もそれぞれ 9,10 施設で主として測定を行ってい る。 

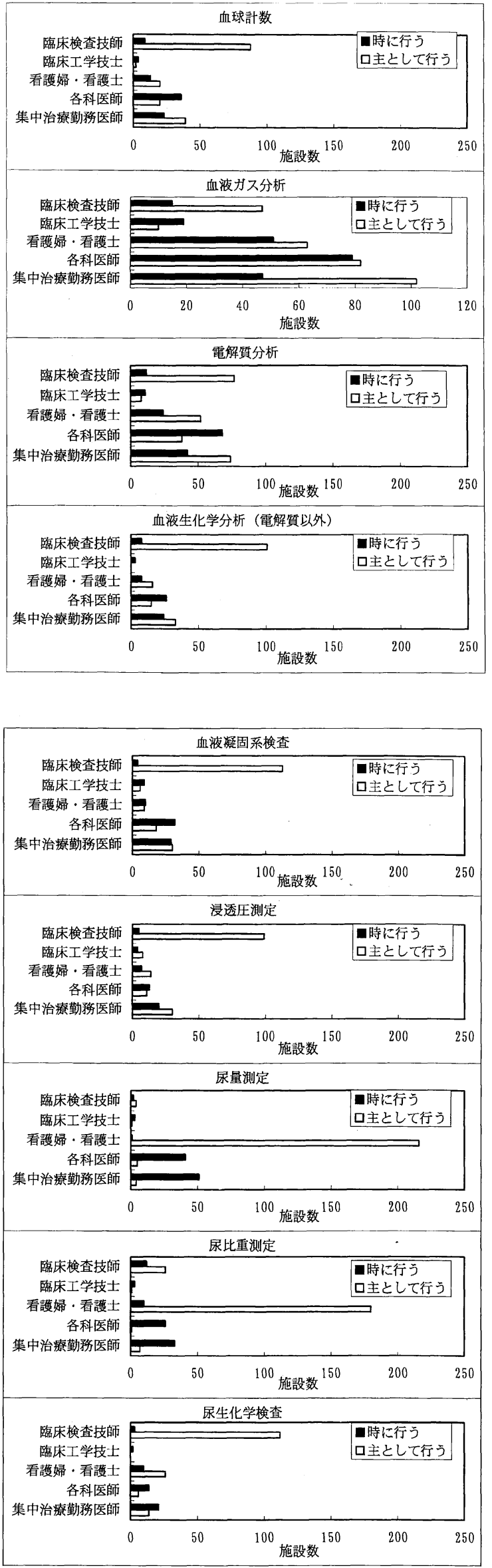

図 49
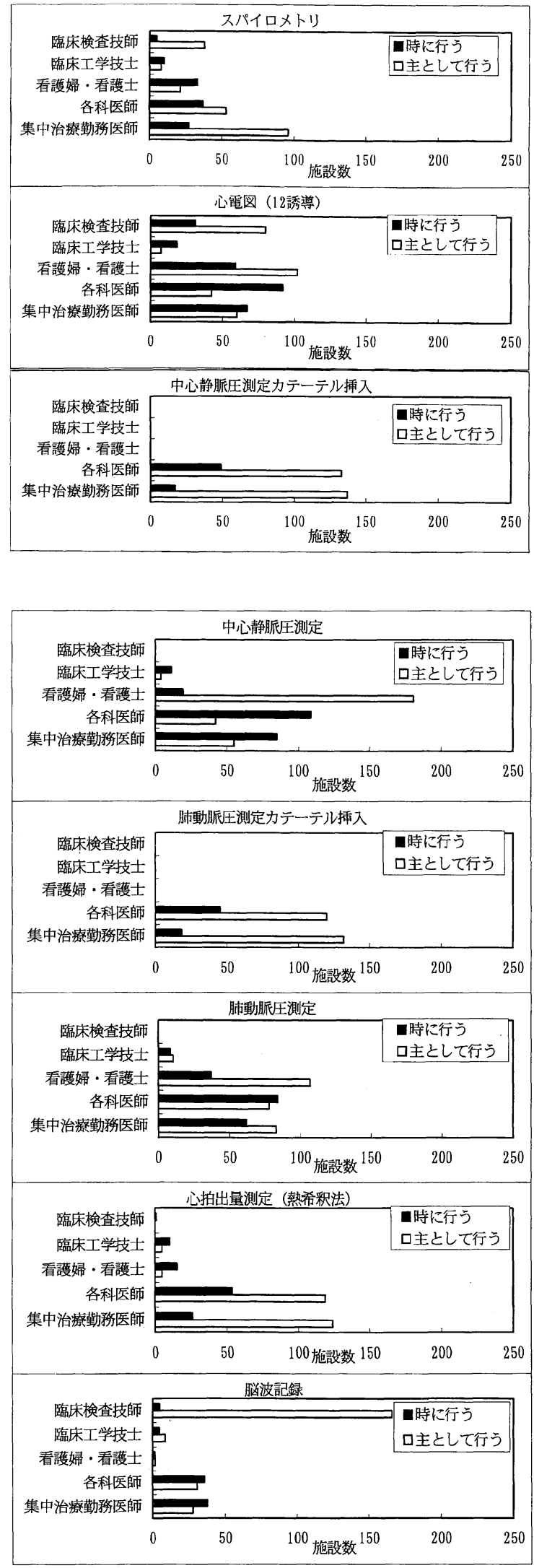

図 50 
c. 画像読影（図 51）

X 線写真の読影については, 各科医師 (140), 集中 治療部医師 (128) が主として行う施設が多く, 主とし て放射線科医に読影を依頼している施設は 46 に過ぎ ない。これに対して，心エコー図については，主とし て循環器専門医が読影している施設が 159 に達し, 集 中治療部医師 (66)，各科医師（52）が主として行う施 設は少ない。

\section{4）各職種の集中治療業務に占める割合}

以上の結果から各業種の役割分担を推定すると,救 命処置については集中治療部医師と各科医師のいずれ かが主体となって蘇生法を行い，ナースがこれを介助 している。集中治療部医師が担当しているのは, 救命 処置に加えてベンチレー夕のセッティング，ペース メーカー調節，ベッドサイドの検査のうち血液ガス測 定，スパイロメトリー, 電解質測定, 中心静脈カテー テル挿入，肺動脈カテーテル挿入と測定，心拍出量測 定，X 線写真読影などである。各科医師は，救命処置 に加えてペースメーカー調節, 補助循環装置装着 (IABP, LVAD, ECMO), X 線写真読影などである。 ナースは, ベッドサイドならびにセントラルモニター の監視，尿量ならびに尿比重測定，心電図記録，中心 静脈圧ならびに肺動脈圧測定を担当している。臨床工 学技士は, 血液浄化装置のセッティングおよび装着を 主となって行い, 補助循環装置の準備装着にもあず かっている。臨床検査技師は，尿量と尿比重を除く検 体検査や心電図記録のほか，脳波記録，脳誘発反応検 査に大きく寄与している。画像読影に関しては，心工 コー図の読影が循環器専門医に多く依頼されている。

\section{H．感染対策}

\section{1）感染防止対策委員会}

a. 設置状況（図 52）：病院全体としての委員会があ ると答えた施設が 210 (91.7\%) あった。病院ならびに 集中治療部独自の委員会があるとの回答 $12(5.2 \%)$ を 加えると，96.9\% の施設で病院全体の感染防止に関す

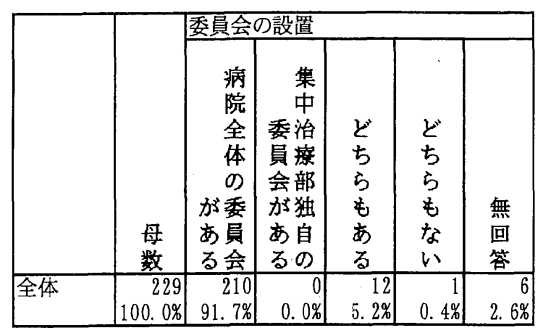

図 52

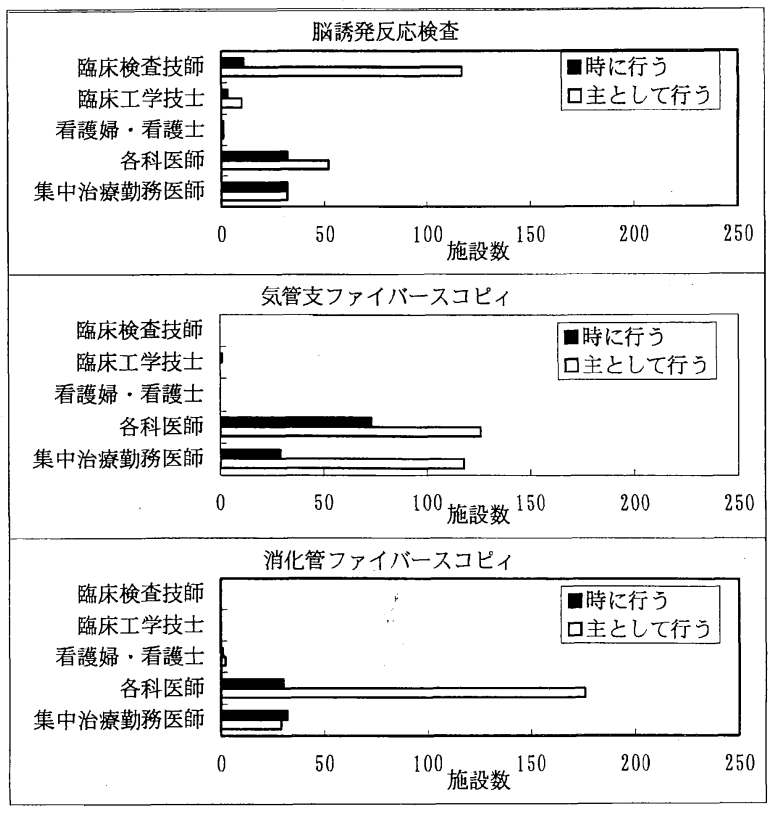

図 50 (つづき)

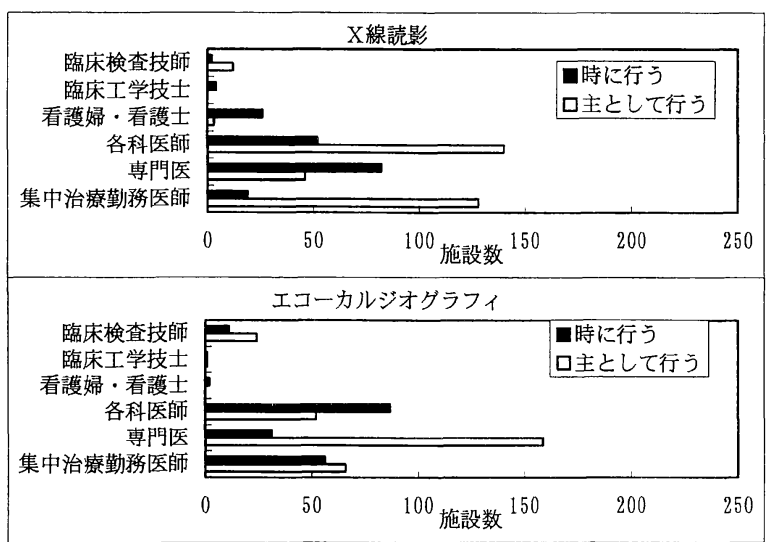

図 51

\section{る委員会がある。}

b. 開催状況（図 53）: 定期的に開催している施設が 134 (58.5\%), 必要に応じて開催しているが84 (36.7\%) である。開催頻度は，年 12 回が 47 (35.1\%)，年 6 11 回が $29(21.6 \%)$, 年 3 〜 4 回が 32 (23.9\%) であ り，年 3 〜 12 回の頻度で定期的に開催している施設 が大半 $(73.7 \%)$ をしめる。

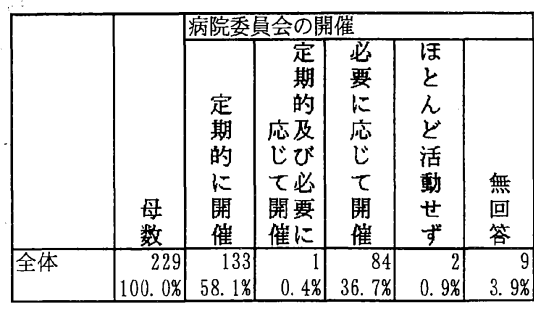

図 53 


\section{2）感染防止対策の内容}

a. 感染防止対策マニュアル（図 54）

152 施設 $(66.3 \%)$ が病院全体としてのマニュアルを 有している。集中治療部独自のマニュアルを有する施 設も計 8 施設 $(3.5 \%)$ ある。対象病原体別にマニュア
ル保有施設をみると，MRSA：210 (91.7\%)，HBV/ HCV：164 (71.6\%), HIV：125 (54.6\%) と近年問題 となっている感染症に対応する施設が多い。一般的感 染防止対策マニュアルを有する施設は $135 （ 59.0 \% ）$ あ る。

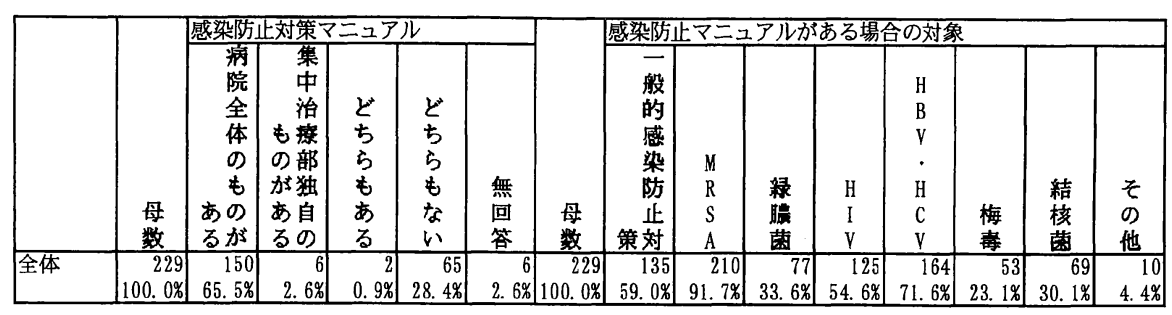

その他内容

ATL

HIVについては防止対策及び受入マニュアルは作成していない

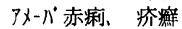

法定伝染病

殆ど全てを網羅してある

流行性角結膜炎

状澼 (2回答)

図54

b. 施設・設備上の感染防止対策（図 55）

(1) 空調条件を他の部署と区別しているかという問い に対して，区別しているとの回答は 229 施設中 174 (76.0\%)であり,残り約4分の1が区別していない $(14 \%)$ か無回答 (10\%) である。

(2) 隔離用個室の保有率は, 全体の 3 分の 1（151： 65.9\%) であり, 保有している場合の室数は, 1 室 (49: $32.5 \%), 2$ 室 (60：39.7\%)，3〜 4 室 (25：16.6\%) と 4 室以内が $88.8 \%$ をしめた。
(3) バイオクリーンルームを保有しているのは 42 施 設 $(18.3 \%)$ であり, 残りは保有せず（79\%）ないし無 回答であった。

(4)-(5) 器材搬入路と搬出路を区別している施設 (22: $9.6 \%)$, 滅菌物専用の器材室を保有している施設 (44: 19.2\%）も全体の 5 分の 1 に満たない。

(6) 污染物専用の処理室を有する施設は, $180(78.6 \%)$ であるが，これに関しては，保有しないと答えた施設 が 44 (19.2\%) あることが問題であろう。

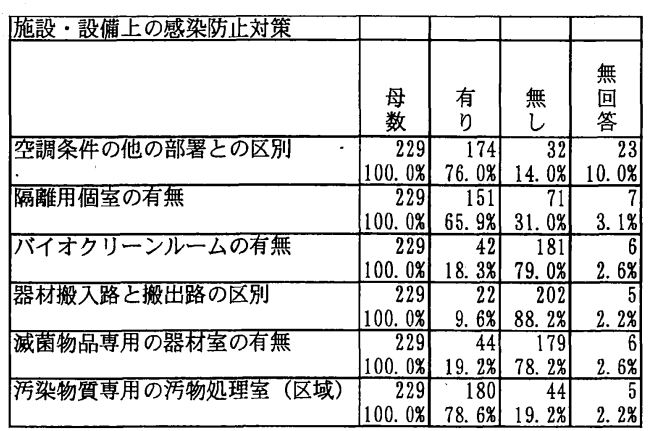

図 55

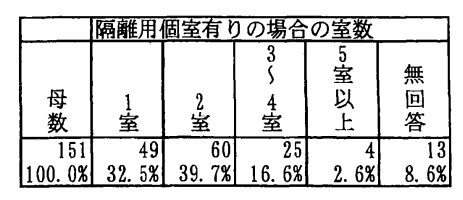


c. 使用機器・物品に関する感染防止対策（図 56）

(1)ベッド、マットレスの消毒を患者毎に行う施設は $104(45.4 \%)$ ，感染症患者使用後は行う施設が 132 (57.6\%) ある。これらの回答は重複している。定期的 に消毒を行う施設は $13(5.7 \%)$ で，その頻度は月 4 回 以上が 4 施設，月 4 回未満が 6 施設である。

(2) 人工呼吸器のヒューミディファイアの消毒に関し ては，患者毎に行う施設が189（82.5\%）ある。しかし， 感染症患者使用後のみ行う施設が $38(16.6 \%)$, 不定期 に行うが $15(6.6 \%)$ ，行わないが 2 施設ある。定期的 に消毒を行う $30(13.1 \%)$ 施設のうち, 月 4 回以上（週 一回以上) 行うのが 14 施設である。集中治療施設とし ては，最低限患者毎ないしは週 1 回以上の消毒を行う ことが望ましいと考えられる。この条件を満たすのは，
$203(88.2 \%)$ 施設である。

(3) 気管支ファイバースコープについては患者毎に消 毒を行う施設が 199 （86.9\%）あるが, 患者毎に行わな い施設が 34 (16.1\%) あり改善が必要である。消毒を 行わないとの回答はなかった。なお, 定期的に行う施 設は 1 あり，その頻度は毎日との回答である。

(4) 細菌フィルタなどによる人工呼吸器の排気の清浄 化などの処理を行っているのは, 全体の約半数 (108： $47.2 \%$ ) である。今回の調査では人工呼吸器回路 (Yピー ス）細菌フィル夕を装着しているかどうかについては 質問項目がないので，排気清浄化処理が行われていな いことが必ずしも交差感染対策の不備を意味するわけ ではない。
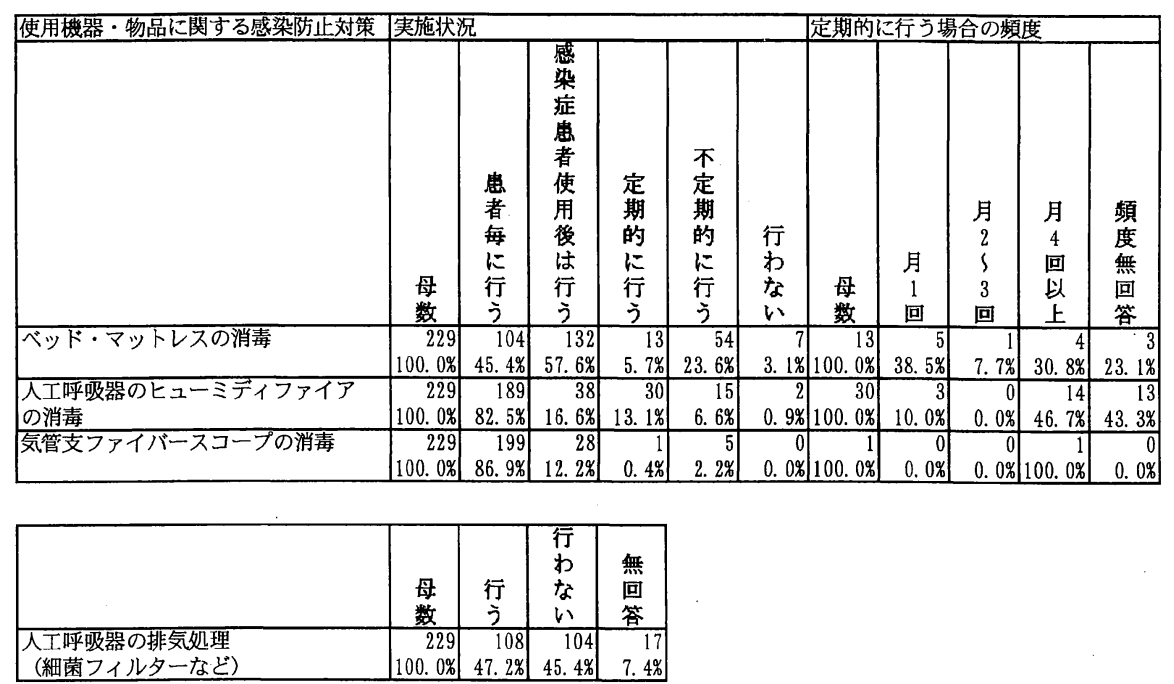

図 56 
d. 医療材料，污染物質の取り扱い（図 57）

(1) 使用済みのリネン類の取り扱いについて, 感染症 患者のものとそうでないものとを区別して処理してい る施設は $203(88.6 \%)$ あるが，区別せず，ないしルチ ンには区別していない施設も約 $8 \%$ ある。

(2) 血液や分泌物で污染されたものを, 全患者につき 区別して処理しているのは108(47.2\%) 施設, 感染症 患者のもののみ区別しているのは $112(48.9 \%)$ である。 血液, 分泌物は, すべて污染物質として処理すること が望まれる。
(3) 污染物処理の場所と搬出ルートについては, 集中 治療棟で処理後搬出する施設が 93 (40.6\%), 処理はし ないが污染物を別ルートで搬出するのが $62(27.1 \%)$ あ る一方，そのまま一般物と同一ルートで搬出する施設 が $57(24.9 \%)$ ある。

(4) 注射器, 刃物の廃棄については, 医療従事者なら びに廃棄物処理業者の感染の危険性が問題となってい る。これらの廃棄に際し, 専用容器を用いている施設 は 201 （87.8\%）と多い一方で，使用せずないし無回 答が $21 （ 9.2 \% ）$ あ。

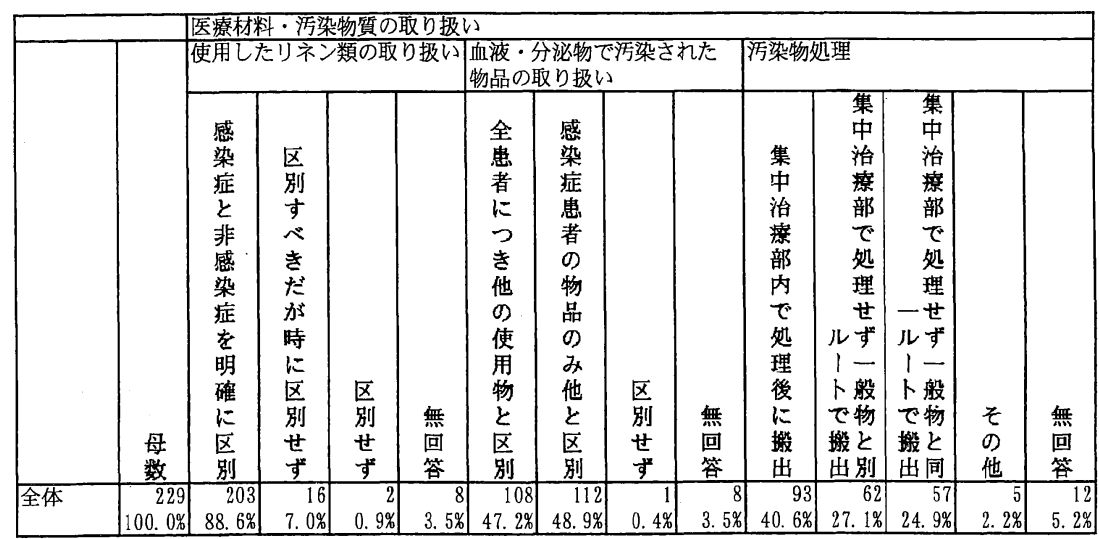

\begin{tabular}{|c|c|c|c|c|c|}
\hline & & 注射釬 & 邓物 & 搳てる & \\
\hline & $\begin{array}{l}\text { 母 } \\
\text { 数 } \\
\end{array}$ & 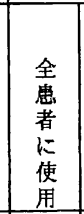 & 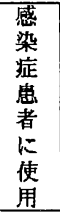 &  & $\begin{array}{l}\text { 無 } \\
\text { 回 } \\
\text { 答 }\end{array}$ \\
\hline 全体 & $\begin{array}{r}22 \\
100.0 \% \\
\end{array}$ & \begin{tabular}{|c|c|}
9 & 201 \\
6 & $87.8 \%$ \\
\end{tabular} & $3.1 \%$ & $\begin{array}{r}15 \\
6.6 \% \\
\end{array}$ & $\begin{array}{r}6 \\
2.6 \% \\
\end{array}$ \\
\hline
\end{tabular}

図 57

e. 部屋の消毒（図 58）

患者退室毎に病室の床・壁面の消毒を行う施設は 79

(34.5\%)，感染症患者退室後に消毒を行う施設は 133
(58.1\%) ある（複数回答）。定期的に消毒を行う施設は 44 (19.2\%) であるが，その頻度は高くない。

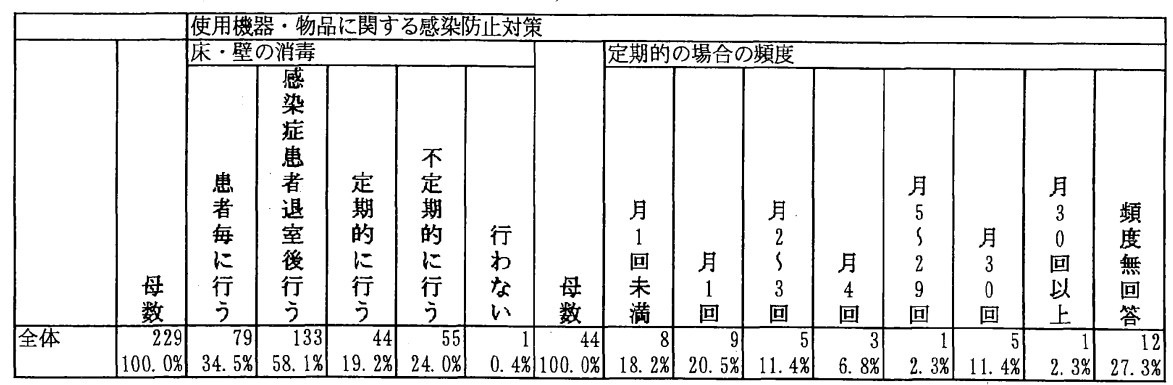

図 58 
f. 集中治療部勤務者，訪問者についての

感染防御対策

(1)各科医師（図 59）が集中治療棟に入室する際, 約 $90 \%$ の施設で履き物を替え，手洗いをしている。 ついで頻度の高いのは，ガウン着用 $(66.4 \%)$, 帽子 着用 $(53.3 \%)$ ，マスク着用 $(45.9 \%)$ である。これ に対して，専用ユニフォームの着用（専従：34.1\%， 各科医師：14.8\%を除いて、集中治療部の専従医師
（図 59）が入室する際に履き物を替え（75.5\%），手 洗いをし $(72.5 \%) ，$ ガウン $(32.8 \%)$ ，帽子 (48.0\%)， マスク (33.2\%) を着用する施設の数は各科医師の それより低い。この理由は不明であるが、専従医師 が各科医師とは別の入室経路を取ることが多い、専 従医師の慣れによるルーズさ、入室患者との意志疎 通のためマスクをしない、などが考えられる。

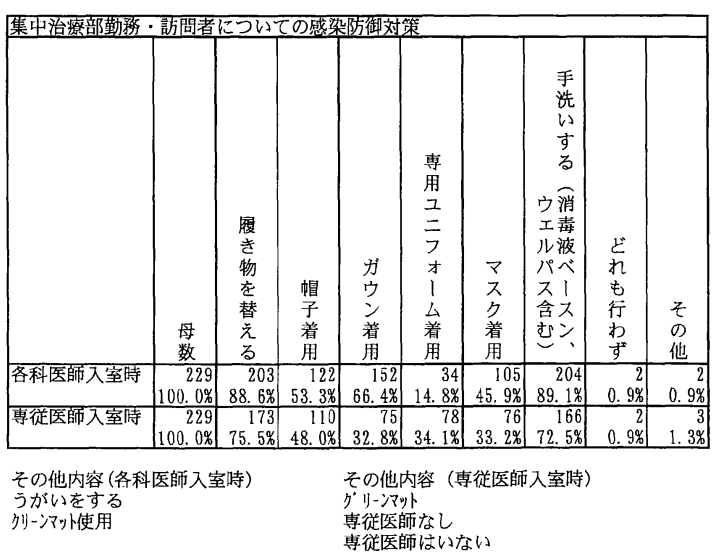

図 59-A

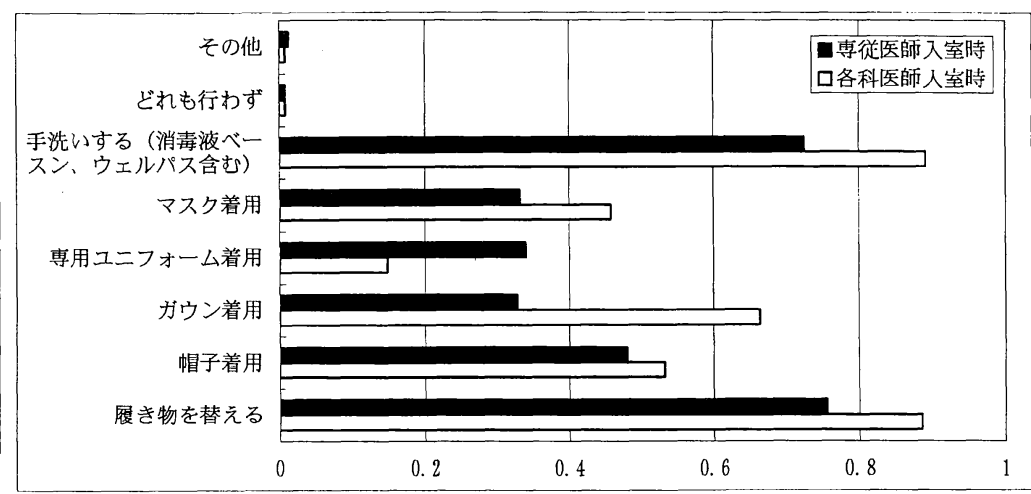

図 59-B

2)専従看護婦（土）（図 60）の場合は、専用履き物 $(86.5 \%)$, 手洗い $(85.6 \%)$, 専用ユニフォーム $55.9 \%$ な いし病院制服の上にガウン着用 $(21.4 \%)$ ，など専従医 師よりも感染防御に配慮しているように見える。しか

し、マスクの着用率 $(32.8 \%)$ は専従医師と変わらない。 上述のように，患者との意志疎通の上で通常はマスク を避けているものと思われる。

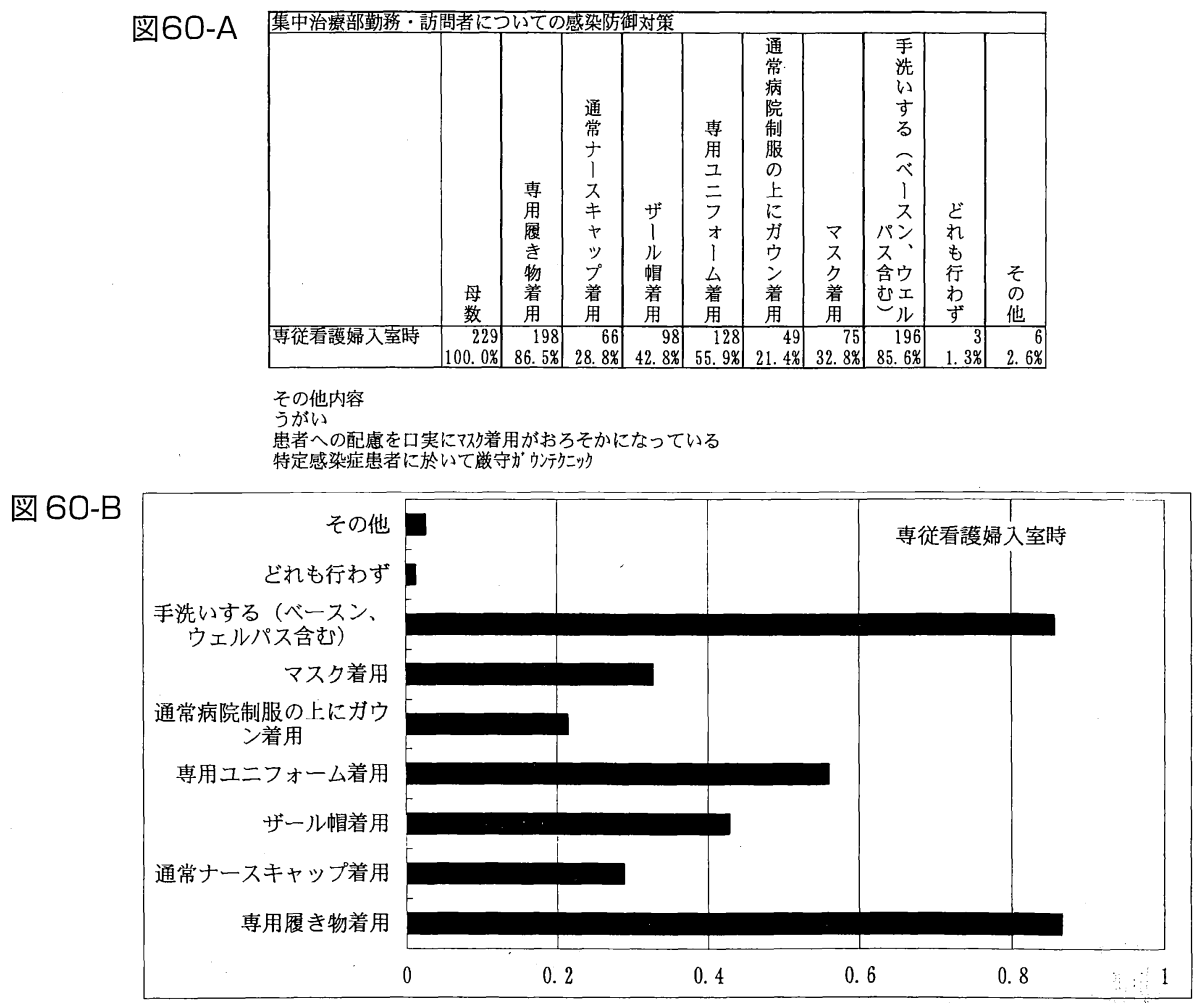


(3)一般入室患者 (図 61) に対して診察, 処置, 看護・ 介護を行うときの手指の消毒については，患者毎にア ルコールで行う施設が最も多い。ついで, 消毒液・流 水での手洗いが多く, 滅菌ないし非滅菌手袋の使用は
40数パーセントの施設で行われている。これらの使用 頻度は，いずれも看護婦（士）に高く医師に低いのが 特徴的である。有効性が問題視されている消毒液ベー スンによる手洗いを行う施設は，約 $5 \%$ である。

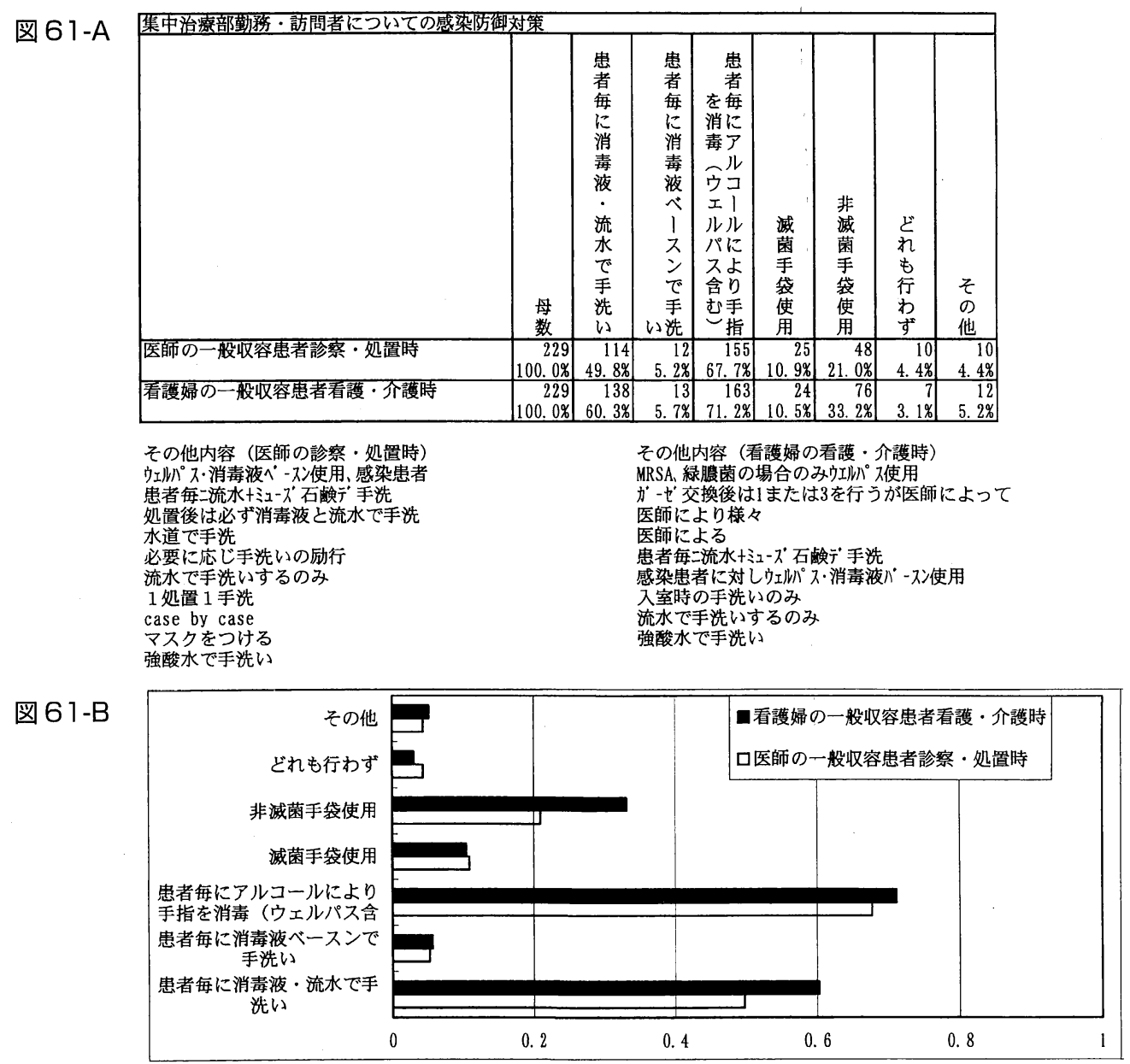


(4)放射線技師, 臨床工学技士, 臨床検査技師の入室 時の感染防止処置（図 62）は, 手洗いが $69.0 \%$ とやや 低いのを除くと, 各科医師と同様である。これらのコ
メディカルは，患者と直接接触する機会が少ないこと が手洗いの施行比率の低下に反映されていると思われ る。

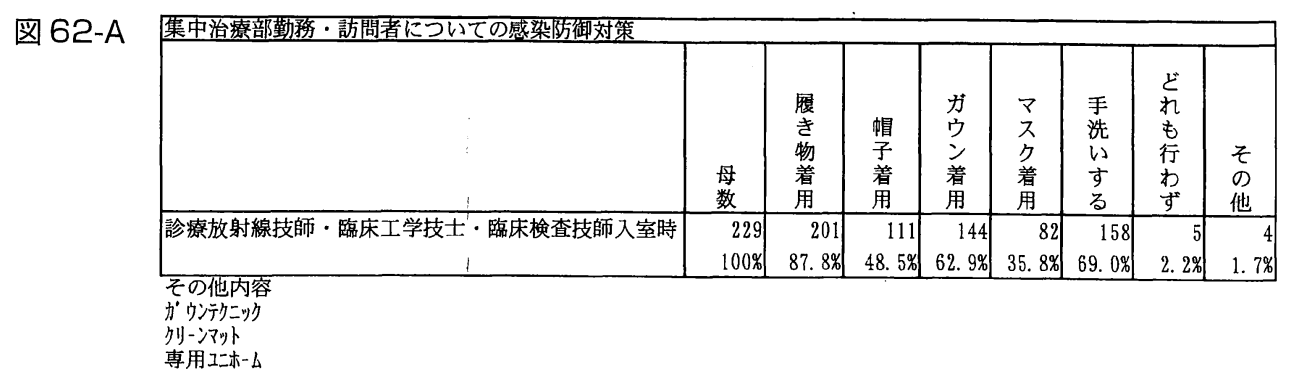

図 62-B

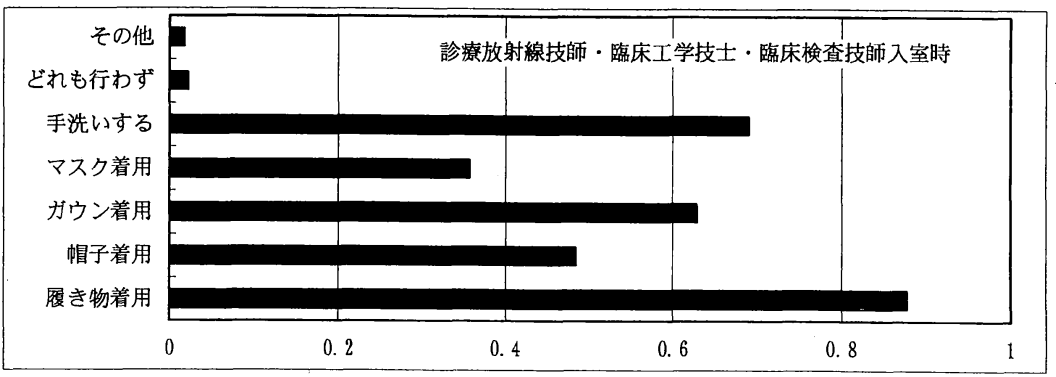

(5)面会者入室時の感染防止処置（図 63）は, 医療従 事者のそれに比してすべての項目において上回ってい る。面会者が直接患者に接触することは少ないと思わ
れるが，清潔区域であるとの認識を与えるためとも考 えられる。

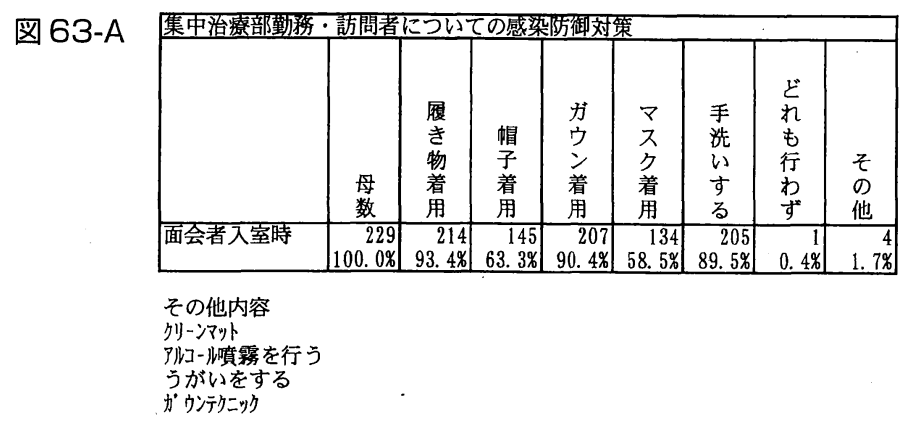

図 63-B

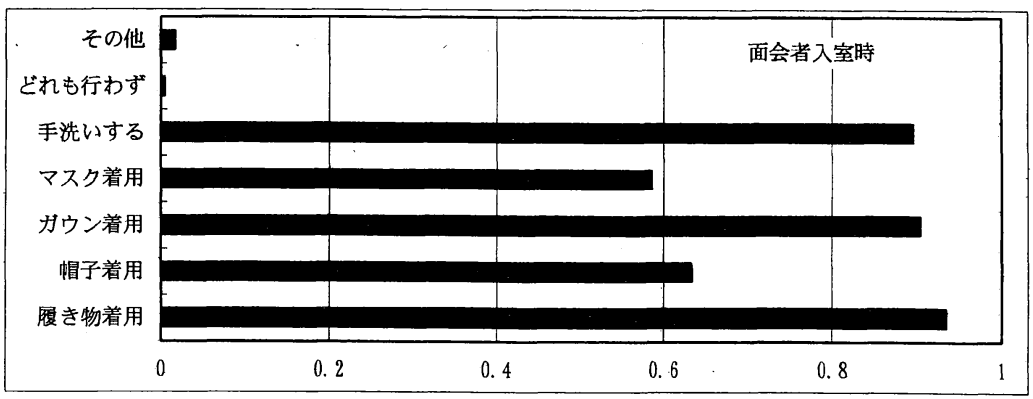


(6)面会者（図 64）に対する面会回数，面会時間，1 回の人数の制限は，ほとんどの施設で行われている。 面会回数は 2 回が 98 (42.8\%) と最も多く, ついで 3 回以上が 76 (33.2\%),

1 回は 40 (17.5\%) と無回答以外では最も少ない。面
会時間は 10 分以内が 114 (49.8\%)

施設と半数であり，30 分以内を合わせると 187 (81.7\%) を占める。1 回の面会人数は 3 人以内の施設 が 191 （83.4\%）である。

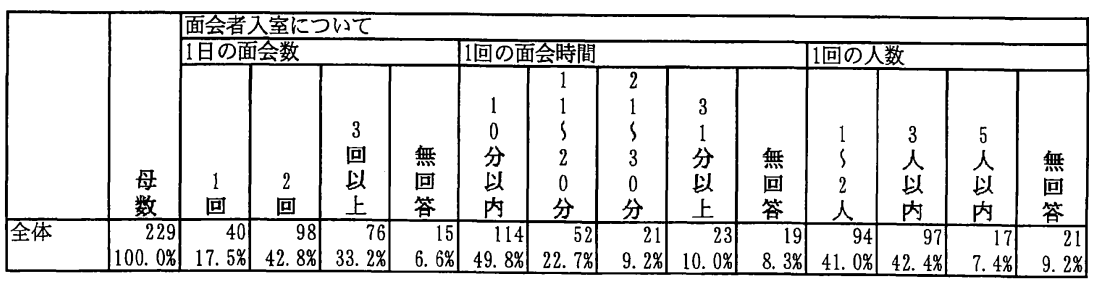

その他の制限をしている（10件）

(内容)

1回の人数は特に制限しない

2 名10分間

ケースによる

一人づつ交替で入室する

患者の状態や家族の事情を考慮して変更

主治医の許可があれば自由或いは患者により面会時間を

必要に応じて回数・時間は弾力的に変えている

必要及び家族の希望があれば適時変更

面会者を入室させないことを原則とする

余り規制していないが10人以上の場合は注意している

図64

(7)医師, 学生・見学者の入室制限（図 65）について は，医師の入室制限を行うのは 2 施設のみである。学
生・見学者については 70（30.6\%）施設が入室制限を 設けている。

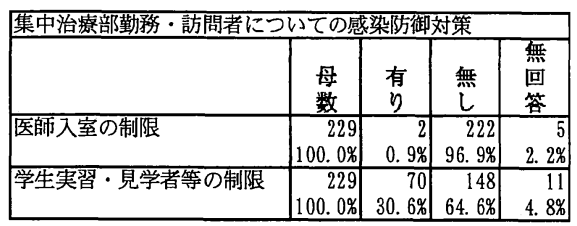

図65 
g. 感染防止対策の評価としての細菌検査（図 66） 医師・看護婦（士）の手指細菌検査を定期的に行っ ているのは，わずか $27(11.8 \%)$ 施設で，不定期に実 施を合わせても約半数である。定期的に行っている場 合も，月 1 回はわずか 3 施設で，他は 1 ケ月未満（6ケ 月ないし年に 1 回）である。細菌検査を実施していな い施設が $112(48.9 \%)$ と約半数を占める。

鼻腔内分泌物の細菌検查は，定期的に行っている施 設が 19 (8.3\% にすぎない。その場合に月 1 回以上行 うのは 6 施設で，他は月 1 回未満 (9 施設) か無回答 である。細菌検査を実施していない施設は106 (46.3\%) ある。

人工呼吸器回路内の細菌検査を定期的に行う施設は, 9 (3.9\%) ときわめて少ない。不定期の実施も 78 (34.1\%) で，両者を合わせても半数に満たない。呼吸
回路の場合, 最近はほとんどの施設でディスポーザブ ルが用いられているためかもしれない。

病床部分の床面については，定期的細菌検査を 62 (27.1\%) 施設，不定期には $119(52.0 \%)$ の施設で行っ ている。定期的に実施している施設のうち, 25 (40.3\%) が月 1 回以上の検査を行っている。細菌検査を行って いないとの回答は 38 (16.6\%) と医療従事者の手指・鼻 腔, 人工呼吸器回路と比較すると最も少ない。

集中治療棟の感染防止対策として, どんな検体を対 象にして，どれだけの頻度で細菌培養検査を行うべき かについては明確な解答はない。しかしながら，集中 治療棟における交差感染の経路を明らかにし，それを 防止するためには一定の基準を設けて細菌検査を定期 的に実施すべきものと思われる。

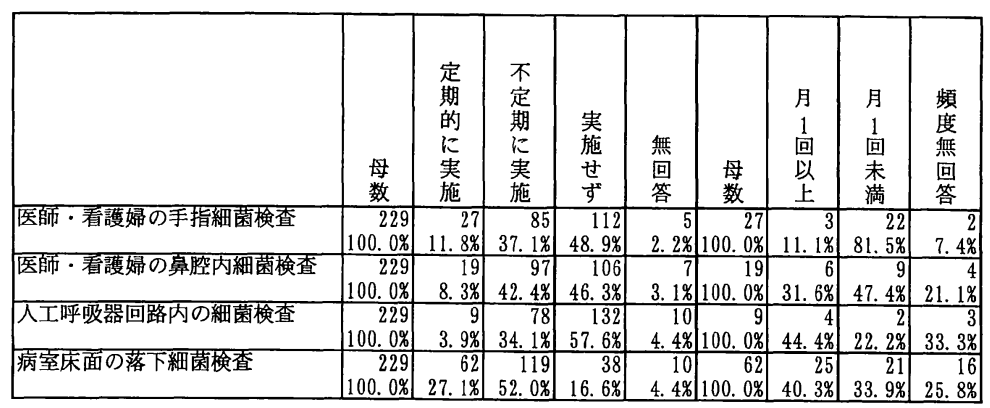

その他の評価を行っている（5件）

(内容)

2日每に回路交換、オートレープ滅菌

回路加湿器交換は 3 月毎が理想という結果を得ていないので(以下略)

回路交換週 2 回行っている

定期的に行う事を予定。

毎回交換·加 久堿菌

図 66-A

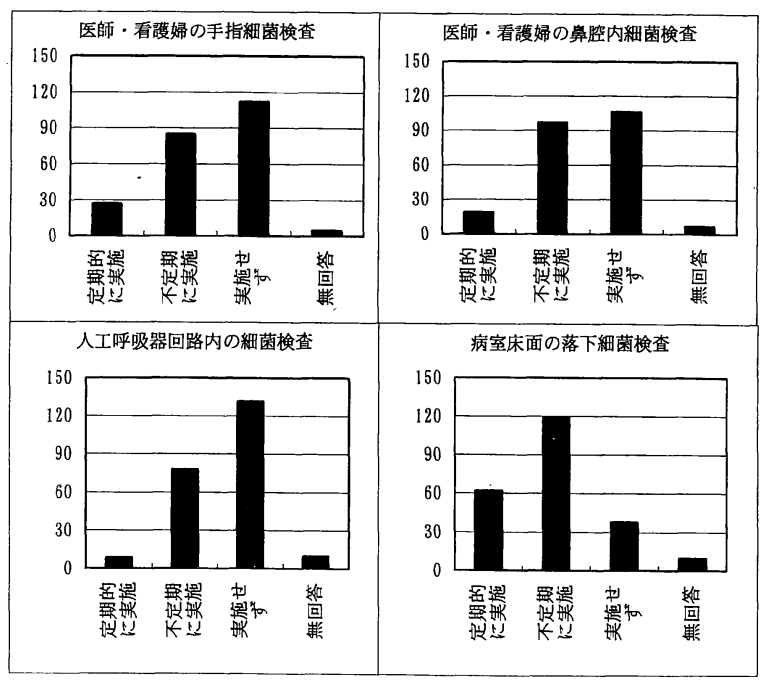

図 66-B 
h. 感染症患者への対処について

(1)感染症患者の入室（図 67）を断ることがあるかの 問いに対して，118（51.5\%）の施設が断ることがある としている。入室を断る場合の対象病原菌は, 118 施 設 MRSA 84 (71.2\%), 結核菌 79 (66.9\%) が多い。HIV は $14(11.9 \%)$, 緑膿菌は 11 (9.3\%) の施設が断る対象 にしている。HBV, HCV, 梅毒を断る対象にあげた施 設はない。
感染症患者の入室を断らないと答えた施設で，入室 基準を厳しくするかどうかの問いに対しては，一般患 者と同様との回答が $77(33.6 \%)$ ，より厳しくするとし たのが $61(26.6 \%)$ 施設で, 残りは無回答であった。入 室基準を厳しくする場合の対象は, MRSA, 結核菌, 緑 膿菌，HIV，HCV，HBV，梅毒の順であり，前問と同 様にHIVに対して特に厳しくするという傾向はみられ ない。

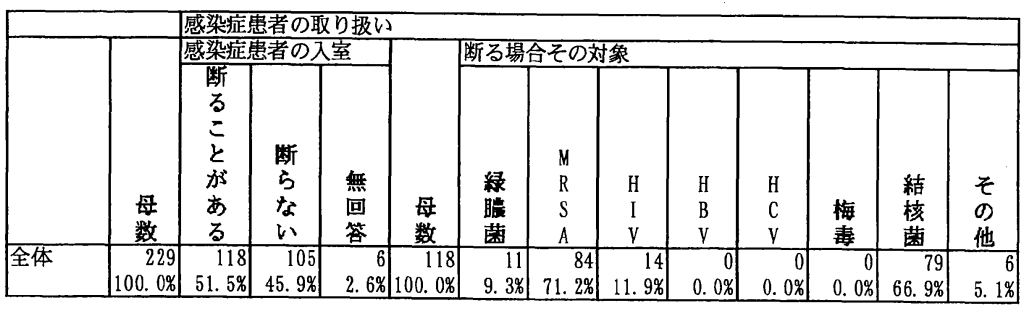

その他内容

HIVに関しては現在検討中。院内での取扱い未決定

風邪

風疹等

法定伝染病

麻疹·水痘等の感染症

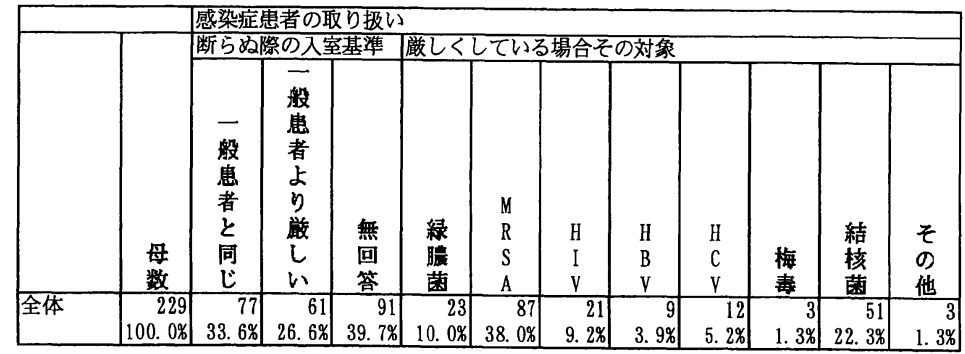

その他内容（縟しくしている場合）

排菌のある結核菌患者は重症な場合にのみ一限る

本来の2床部屋を1人の感染患者の隔離に用いる場合

図 67 
(2)個室を有する集中治療棟（図 68）に対して, 感染 症患者を個室に収容する場合の病原菌を聞いたところ, 収容するとの回答数は, MRSA（152），結核菌（88）， HIV (47)，緑膿菌（44），の順である。また，個室は あるが総室で隔離技術を実施する場合の対象病原菌は, MRSA (回答数: 95), 緑膿菌 (59), 結核菌 (44), HCV (43), HBV (41), HIV (32), 梅毒 (16) と病原菌に
よって取り扱いを大きく変えているわけではない。こ こでも, HIV を特別視していないことがわかる。 集中治療棟に個室が無い場合（図 68）について，隔 離技術を実施する病原菌をあげた結果は,やはり MRSA, 結核菌, 緑膿菌, HIV, HCV, HBV の順であ り，いずれの場合もMRSAが最も交差感染に関して問 題視されていることがわかる。
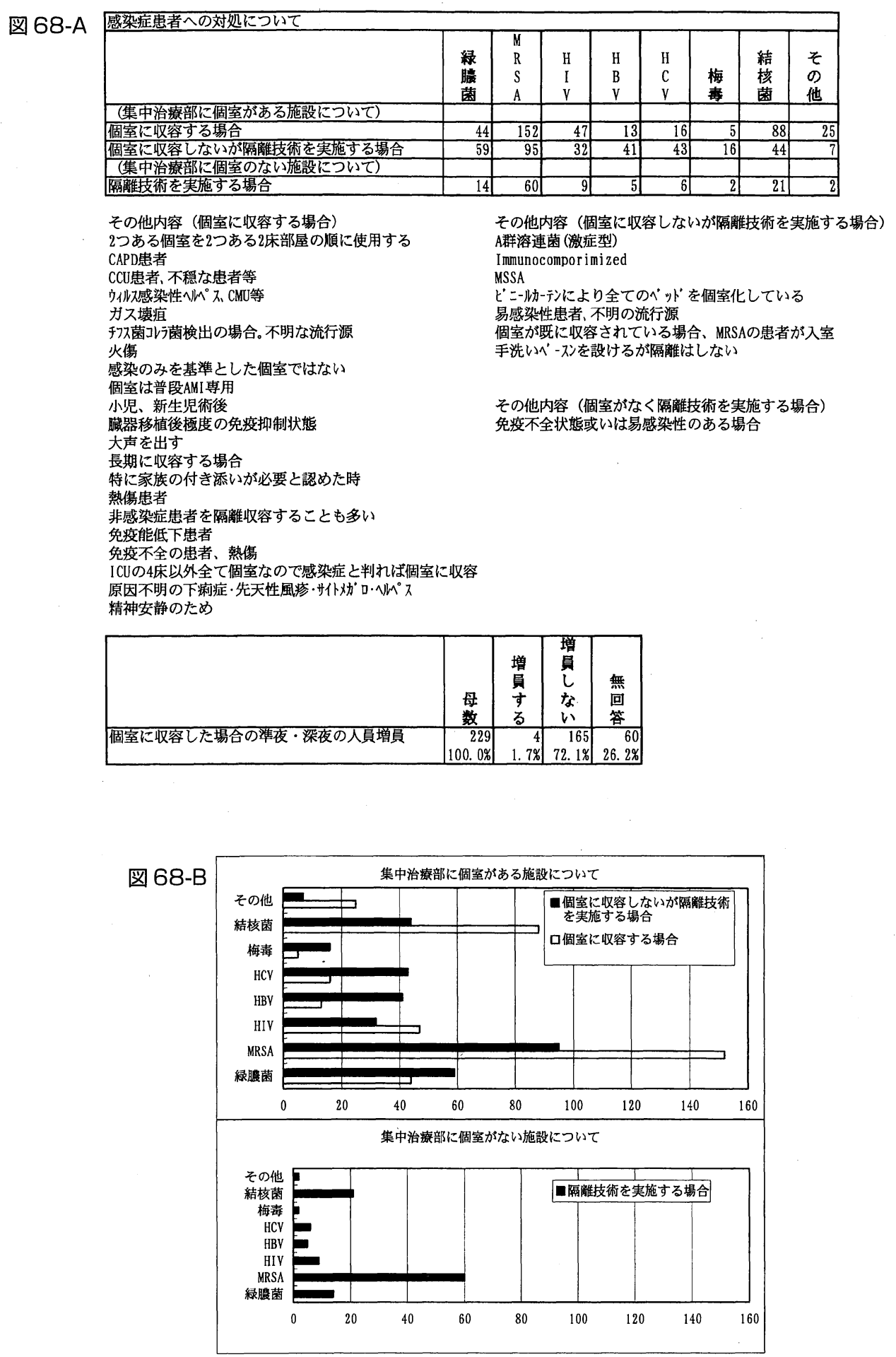
(3)感染症に対して隔離技術（交差感染防止対策）を 要する患者を最大何人引き受けられるか（図 69）の問 いに対しては，2 人が55（24.0\%）施設で最も多い。集 中治療棟ベッド数別にみると, 1 〜 床の規模では 1 人 $(25.0 \%), 2$ 人 $(22.2 \%)$ ，そして 4 人 $(36.1 \%)$ に回 答が集中している。4 人との回答は，全べッドで収容 可能であることを意味する。これに対して，5～8 床 では $1 \sim 2$ 人, $9 \sim 12$ 床では 2 人， 13 床以上では 2 ～ 3 人に回答数のピークがあり, ベッド数に比例して 収容可能数が増加するのではないことを示している。

(4)隔離技術の内容（図 70）を，個室の有無を問わず 回答を求めた。大多数の施設で, 専用ガウン, アルコー ルによる手指消毒，専用履き物，専用手洗い，専用マ スク，カーテン・衝立てで仕切る，隔離技術を実施し ている。半数以下の施設にしか採用されていないのは, 専用帽子 $(40.6 \%)$ と滅菌手袋 $(33 / 6 \%)$ である。隔離 技術に関しては，その他感染防止対策として特に留意 している事項として，数多くのコメントが記載されて おり，感染防止に関する関心の高さをうかがわせる。

i. 感染対策についてのコメント（図 71）

感染防止対策として留意すべき事項としてあげられ たコメントを分類すると図71のようになる。医療従事 者の手指消毒をあげたコメントが最も多い。

\section{I. 空調・電気設備設置状況}

1）集中治療棟の空調システム（図 72）

a. 229 施設中 $208(90.8 \%)$ が一般病棟から独立し た空調設備を有している。一般病棟と共通と答えたの は $11(4.8 \%)$ で，他は救急部，手術部などと共通の空 調設備を有する。

b. 換気方式については，全新鮮空気方式が 89 (38.9 \%)，リターン方式が81 (35.4\%)，両方式併用が11 (4.8 \%)である。また，自施設の空調方式がわからないと したのが 29 (12.7\%) あった。1 時間の換気回数にな ると，67(29.3\%) がわからないと答え， $44(19.2 \%)$ が設定せずと答えた（図 73）。
図 69



図 70

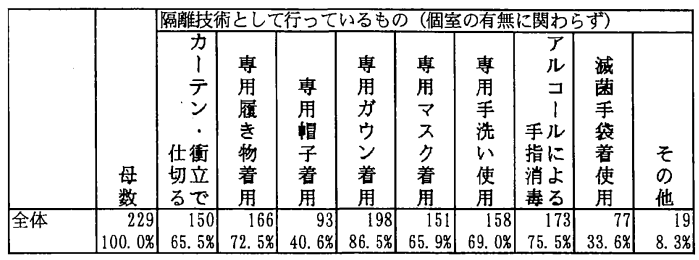

図71

\begin{tabular}{|l|r|}
\hline \multicolumn{1}{|c|}{ コメントの内容 } & \multicolumn{1}{|c|}{$\begin{array}{l}\text { 件 } \\
\text { 数 }\end{array}$} \\
\hline ゾーニング・個室・空調 & 18 \\
\hline $\begin{array}{l}\text { 感染症患者に対する人員 } \\
\text { 配置 }\end{array}$ & 5 \\
\hline 医療従事者の手指消毒 & 38 \\
\hline $\begin{array}{l}\text { 患者の手指・鼻腔の消 } \\
\text { 毒、検査 }\end{array}$ & 4 \\
\hline 医療器具の消毒、滅菌 & 5 \\
\hline ディスポ製品の使用 & 4 \\
\hline 污染物の取り扱い & 4 \\
\hline 医療従事者の教育 & 2 \\
\hline 部屋の消毒 \\
\hline $\begin{array}{l}\text { 面会人など入室者への清 } \\
\text { 潔処置 }\end{array}$ \\
\hline
\end{tabular}

図72

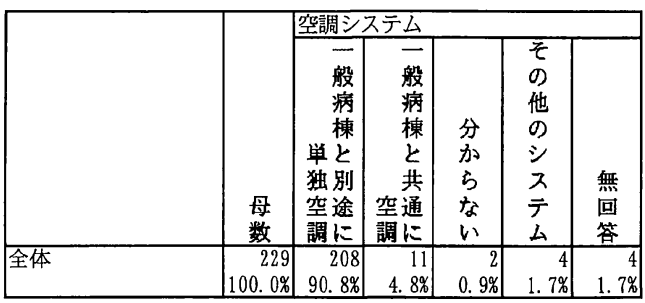

その他の空調システム

ある程度は室内コ吅-炑可能

一部共通（手術部と）

一部単独

一部病棟とは別だが隣の救急センターと共通

冷房は単独, 暖房は一般病棟と共通 


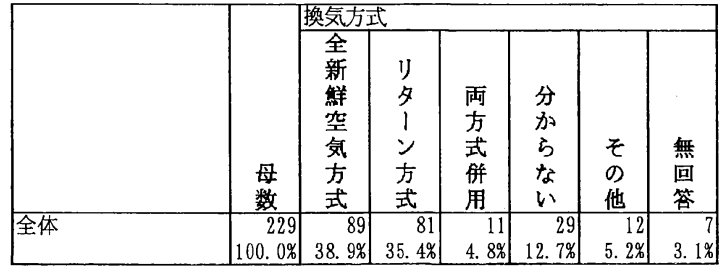

その他の換気方式

口不換気、単独工ア-コ沙夕-汸式

一部新鮮な空気導入

外気、内気混合

外気混合归一汸式

換気扇

固室は全外気, 総室は师-汸式

室内循環

設定していない

半循環方式

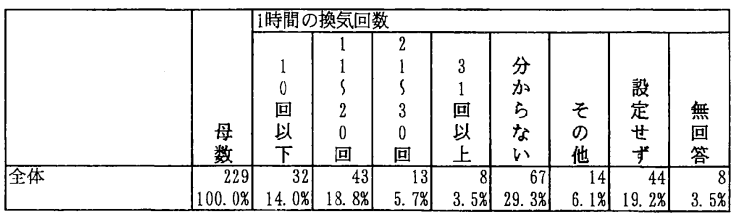

図 73

c. 運転期間は，通年運転が $210 （ 91.7 \%)$ とほとん どであるが，特定月のみの運転も $13(5.7 \%)$ ある。1 日の運転時間については, 通年 24 時間運転を行ってい る施設が $197 （ 86.0 \%$ ）ある（図 74）。

d．温度・湿度の制御については，145（63.3\%）が 温度湿度とも制御を行っているが, $72(31.4 \%)$ は温度 のみの制御にとどまっている。室温の設定は 24.0 〜 $25.9^{\circ} \mathrm{C}$ とているところが 93 (40.6\%) であり，他は $20^{\circ} \mathrm{C}$ 以下から $28^{\circ} \mathrm{C}$ 以上まで広い範囲に散らばってい る。設定湿度は 50 ～59\%が 70 (30.6\%) と最も多かっ たが，無回答が $116(50.7 \%)$ あり，湿度調節は全体と して十分に行われているとは言い難い（図 75）。

図 74

12-3月の暖房と7-9月冷房を24時間で

15時間/日

18 時間

30 時間（暖房）、24時間（冷房）

6月〜11月まで24時間運転

6時〜21時

7 9・12 2は24時間運転、その他は温度を見て運転

AM6:30-21:00

ほほ24時間

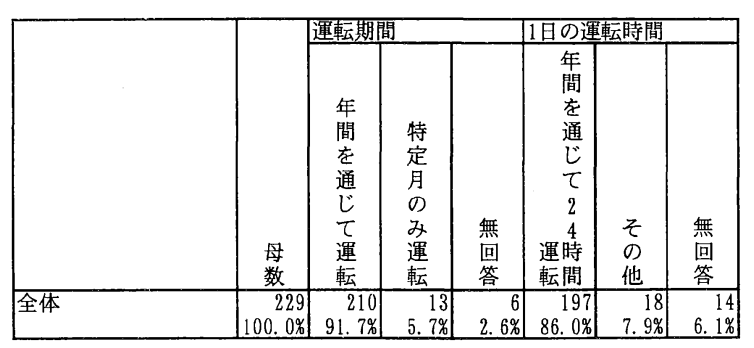

その他内容)

季節によりナースが適宜ス体を入れている

適時

特定月のみ 24 時間

特定月のみ24時間

特定月のみ 24 時間運転

必要あればその時間帯

必要時

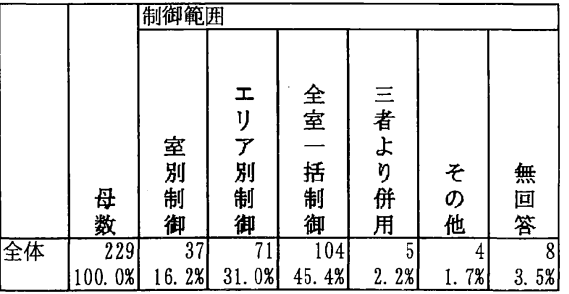

その他の制御範囲)

バ仏夘-ンのみ別制御

一部室制

一部室別制御

各室の風量コ吅-川(強中弱)の3段階

無菌室は室別制御その他は妙別制御

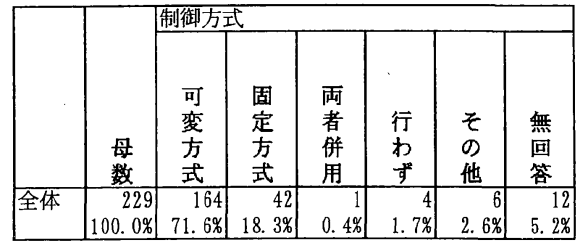

その他の制御方式）

わからない

強中弱の風量のみ

自動制御方式

中央監視室で行う 


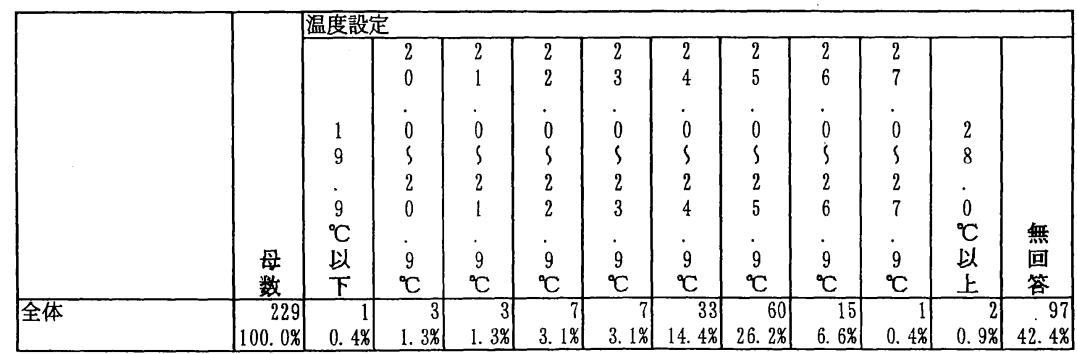

\begin{tabular}{|c|c|c|c|c|c|c|c|}
\hline & \multirow{7}{*}{$\begin{array}{l}\text { 乎 } \\
\text { 数 }\end{array}$} & \multicolumn{6}{|c|}{ 湿度設定 } \\
\hline & & 3 & 4 & 5 & 6 & & \\
\hline & & 0 & 0 & 0 & 0 & 7 & \\
\hline & & s & s & s & s & 0 & \\
\hline & & 3 & 4 & 5 & 6 & $\%$ & 無 \\
\hline & & 9 & 9 & 9 & 9 & 以 & 回 \\
\hline & & $\%$ & $\%$ & $\%$ & $\%$ & 上 & 答 \\
\hline 全体 & 229 & $\begin{array}{r}3 \\
13\end{array}$ & 23 & 70 & $\begin{array}{r}14 \\
14\end{array}$ & $13 \%$ & \begin{tabular}{|r|}
116 \\
\end{tabular} \\
\hline
\end{tabular}

図 75（続き）

e. 感染対策として空気の流れを制御しているかどう かについては，170（74.2\%）が集中治療部と院内他区 域との空気の流れを制御しているのに対し，集中治療 部内における清潔区域と非清潔区域との間の空気の流 れの制御を行っているのは120 (52.4\%)にとどまる(困 76)。

2）集中治療部の電気設備（図 77）

壁，床などのコンセント数は，6～ 10 個が 91 (39.7 \%) 施設と最も多い。ついで $11 \sim 15$ 個 52 施設, 16 ～ 20 個 34 施設と続き 21 個以上の施設も $25(10.9 \%)$ ある一方，5 個以下の施設が $21(9.2 \%)$ ある。



図 76

各ベッド当たりの最大電気容量は $16 \mathrm{~A}$ 以上の施設が 計 $155(67.7 \%)$ を占めた。各ベッド当たりのコンセン 卜必要数と必要電気容量の問いに対しては, $206(90.0$ \%) の施設がコンセント 6 個以上，168（73.4\%）の施 設が 16 A 以上の容量が必要と答えた。
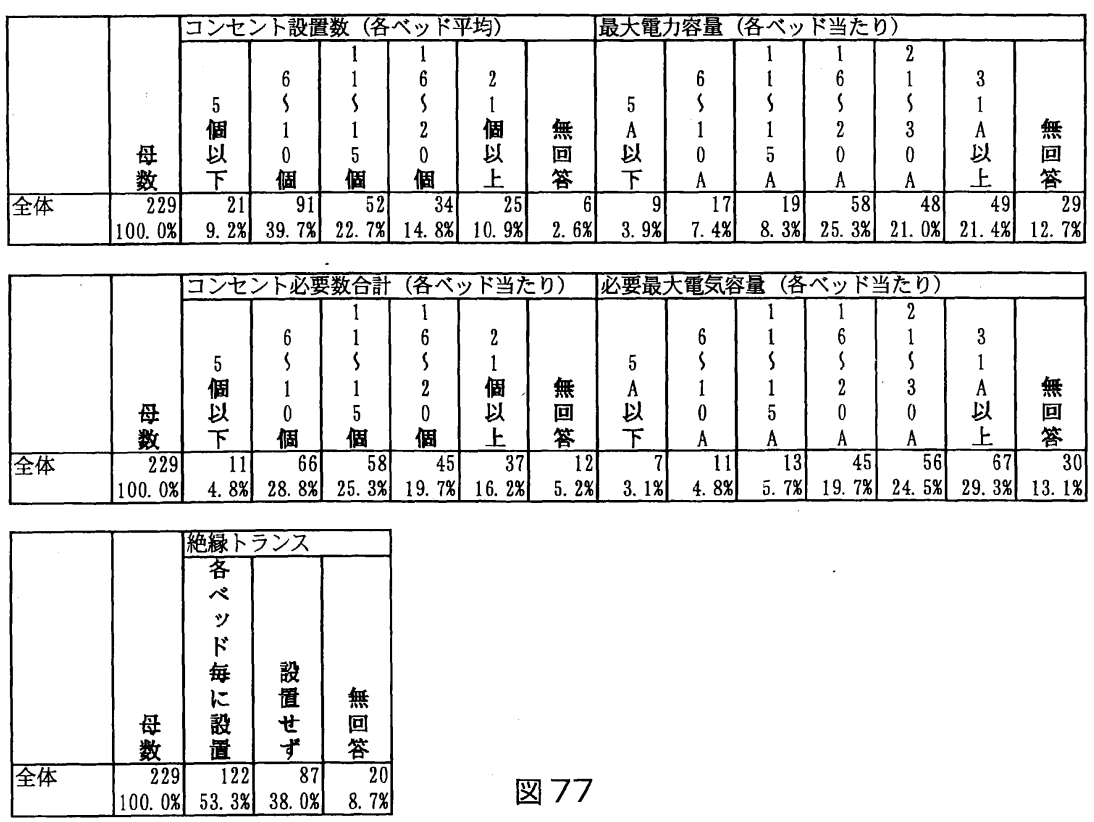
3）電力供給設備（図 78）

a. 集中治療部の停電の有無については，152（66.4 \%)の施設が無しと答えた一方，71 (31.0\%) の施設が 停電を経験している。停電回数は 1 階が 42,2 回が 21 , 3 回が 7,4 回が 1 施設である。最長停電時間は, 71 施 設中 5 分以内が $56(24.5 \%), 6 \sim 10$ 分が $7,11 \sim 30$ 分が $6,31 \sim 120$ 分が 4,120 分を越える停電も 6 施
設にあった（図 78）。

停電の理由を病院側のそれと電力会社からの送電の 問題に大別すると，容量オーバー（8 件）と点検時の 停電（4 件）の計 12 件が病院側の理由と考えられた。 電力会社からの送電が停止したのは 25 件で, そのうち 落雷, 台風, 地震と記載されたものが 20 件あった。

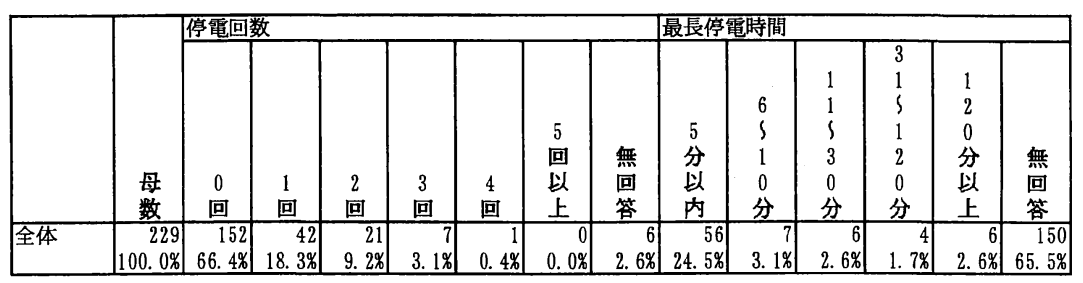

注）工事等意図的な場合を除く

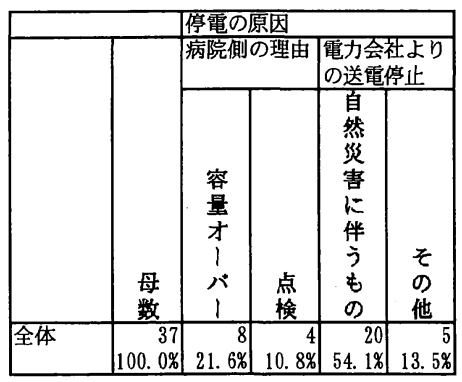

注) 回答のあったものに限った b. 非常用電源（図 79）については，すべての施設 で自家発電装置を保有している。その立ち上がり時間 は，瞬時が $62(27.1 \%) ， 30$ 秒以内が $90(39.3 \%), 1$
分以内が $56(24.5 \%)$ で，計 $208(90.8 \%)$ の施設が 1 分以内である。立ち上がり時間の最長は 10 分である。 無停電装置を保有するのは $116(50.7 \%)$ 施設である。

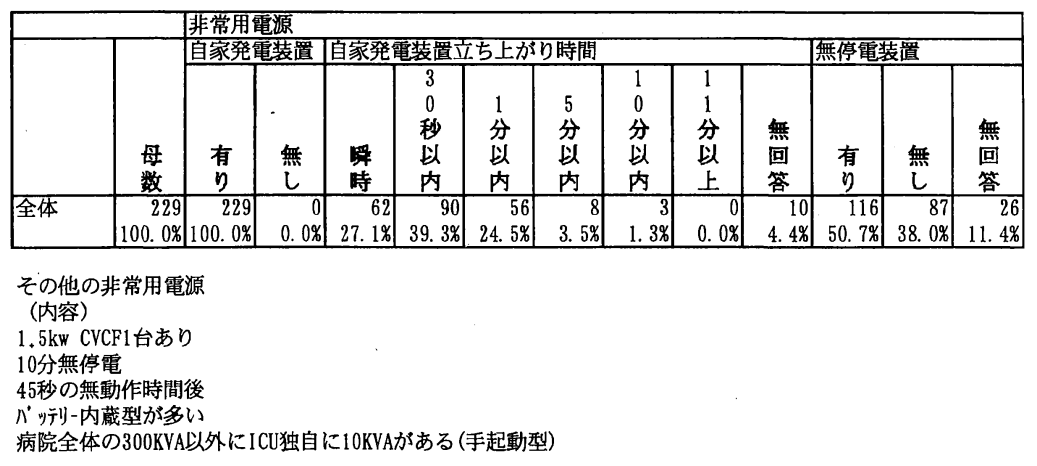

図 79 
図 80-A

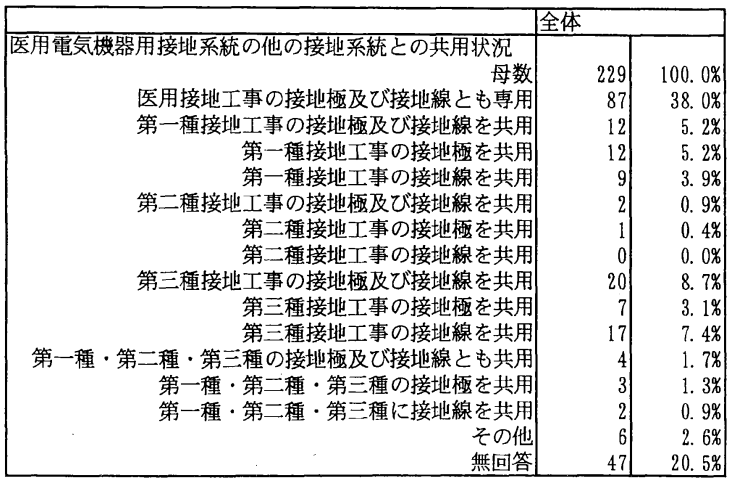

その他内容)

第一種・第二種設置工事の接地線を共用

第一種・第二種接地工事の接地栖及び第三種接地工事の接地線を共用 第一種接地工事の接地極及び第二種・第三種接地工事の接地線を共用 第一種接地工事の接地極及び第二種・第
第一種・第三種接地工事の接地線を共用

医用接地工事の接地極及び接地線とも尃用・第三種接地工事の接地線を共用

図 80-B

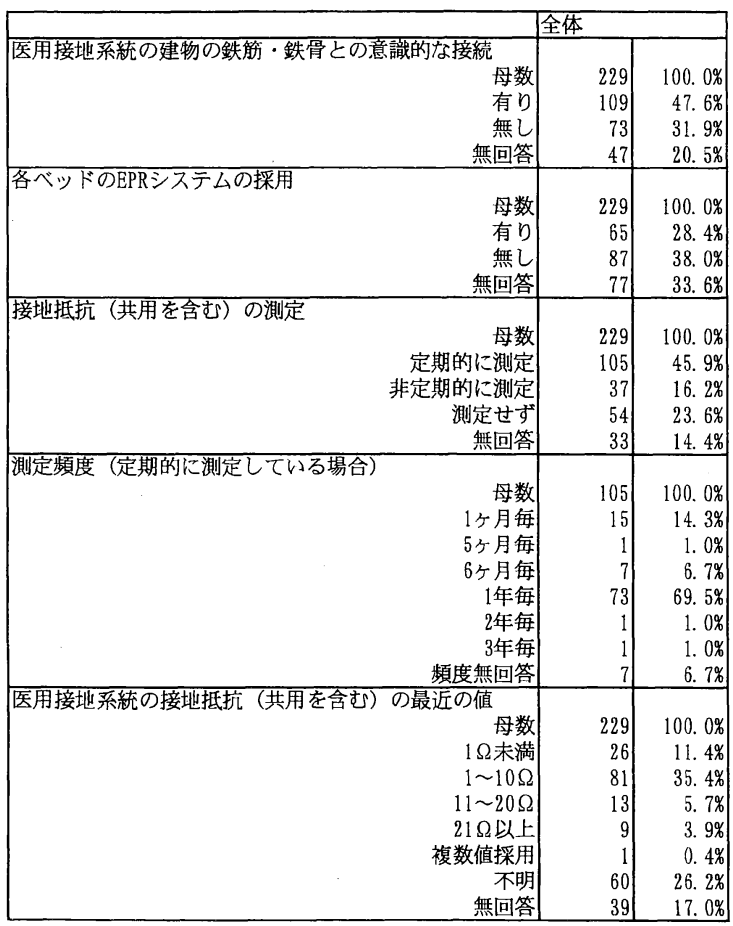

図 81-A

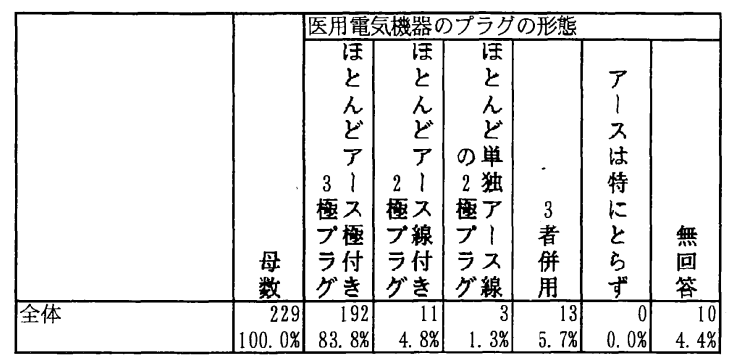

図 81-B

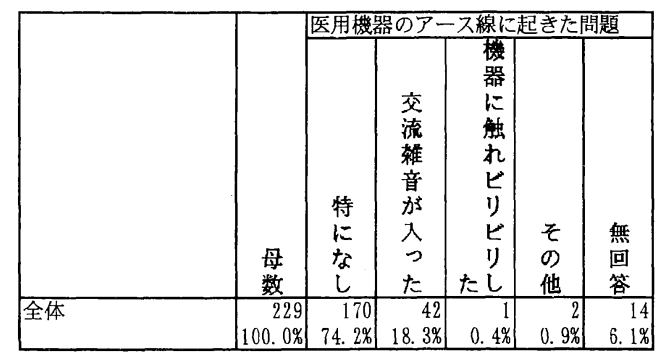

4）接地配線（図 80）

a. 医用接地工事の接地極ならびに接地線を専用とし ているのは $87(38.0 \%)$ 施設で，他は第一，第二，第 三種工事の接地極または接地線を共用している(図80A)。また，無回答の施設が $47(20.5 \%)$ あり，全体と して医用電気機器の接地に関して十分な対策が取られ ているとは言い難い。医用接地系統を建物の鉄骨・鉄 筋と意識的に接続している施設は109 (47.6\%) あるが, 各ベッドへの EPR ( Equipotential Patient Reference System を採用しているのは $65(28.4 \%)$ にすぎない (図 80-B)。

接地配線の点検については，106（45.9\%）の施設で 定期的な接地抵抗の測定が行われている。非定期的測 定は $37(16.2 \%)$ の施設で行われている。一方では，測 定せずと無回答が合わせて $87(38.0 \%)$ ある。定期的 測定の頻度は，1 年毎が $73(69.5 \%)$ と大多数を占め, 1ケ月毎に行っている施設も $15(14.3 \%)$ ある（図 80B)。

医用接地系統 (共用を含む) の接地抵抗測定值は, 1 オーム以下が 26 施設, 1 〜 10 オームが 81 施設と, 10 オーム以下が計 $107(46.8 \%)$ と約半数を占める。不明 と無回答が計 $99(43.2 \%)$ あるので，測定が行われた 施設のほとんどで 10 オーム以下の接地抵抗が達成さ れていることになる（図 80-B）。

b. 医用電気機器のプラグについては, ほとんどアー ス付き 3 極プラグを使用と答えた施設が $192(83.8 \%)$ ある。1 床当たりの 3 極プラグ数は 6 〜 10 個が最も 多い(図 81-A)。

接地に関するトラブルについては，特に無しが 170 $(74.2 \%)$ 施設，交流雑音が $42 （ 18.3 \%)$ 件，機器に触 れピリピリしたのが 1 件，その他，モニ夕ーで異常が 出たが 2 件あった（図 81-B）。 